UNIVERSIDADE DE SÃO PAULO

FACULDADE DE FILOSOFIA, LETRAS E CIÊNCIAS HUMANAS

DEPARTAMENTO DE TEORIA LITERÁRIA E LITERATURA COMPARADA

EZIEL BELAPARTE PERCINO

Murilo Rubião: a bárbara porcelana

[Versão Corrigida]

São Paulo

2012 
EZIEL BELAPARTE PERCINO

\section{Murilo Rubião: a bárbara porcelana}

Dissertação apresentada ao Programa de Pós-Graduação em Teoria Literária e Literatura Comparada da Faculdade de Filosofia, Letras e Ciências Humanas da Universidade de São Paulo para a obtenção do título de Mestre em Teoria Literária e Literatura Comparada [Versão Corrigida]

Orientadora: Profa. Dra. Regina Lúcia Pontieri 
Autorizo a reprodução e a divulgação deste trabalho, por qualquer meio convencional ou eletrônico, para fins de estudo e pesquisa, desde que citada a fonte.

Catalogação da Publicação

Serviço de Biblioteca e Documentação

Faculdade de Filosofia, Letras e Ciências Humanas

Universidade de São Paulo

Belaparte Percino, Eziel

Murilo Rubião: a bárbara porcelana / Eziel Belaparte Percino; Orientadora: Regina Lúcia Pontieri - São Paulo, 2012.

101 f.: il.

Dissertação (Mestrado) - Faculdade de Filosofia, Letras e Ciências Humanas da Universidade de São Paulo, 2012

Área de concentração: Teoria Literária e Literatura Comparada

1. Teoria Literária. 2. Filosofia da linguagem. 3. Lógica 4. Crítica Literária 
Nome: Eziel Belaparte Percino

Título: Murilo Rubião: a bárbara porcelana

Dissertação apresentada ao Programa de Pós-Graduação em Teoria Literária e Literatura Comparada da Faculdade de Filosofia, Letras e Ciências Humanas da Universidade de São Paulo para a obtenção do título de Mestre em Teoria Literária e Literatura Comparada.

Área de concentração: Teoria Literária e Literatura Comparada

\author{
Banca Examinadora
}

Profa. Dra. Regina Lúcia Pontieri

Prof. Dr. Marcos Piason Natali

Profa. Dra. Júlia Maria Costa de Almeida 
A Regina Lúcia Pontieri, orientadora, pela sensibilidade e pelo grande estímulo intelectual. Aos professores Berta Waldman, Claudio Jorge Willer, Cleusa Rios Pinheiro Passos, Giuliana Ragusa, Hélio Rebello Cardoso Júnior, Homero Freitas de Andrade, Ivone Daré Rabello, João Adolfo Hansen, Júlia Maria Costa de Almeida, Luiz Benedicto Lacerda Orlandi, Luiz Krausz, Marcos Piason Natali e Paulo Tarso Cabral de Medeiros, por muitas e distintas contribuições. Aos colegas de graduação e pós-graduação da Universidade de São Paulo. A CAPES, pelo apoio financeiro. A Roseli, claro. 
Murilo Rubião é visto como um caso raro na literatura brasileira: poucos autores produziram como ele uma ficção tão decididamente marcada por situações insólitas, eventos estranhos, cenas inusitadas. Não à toa, sua literatura é estudada a partir de discussões em torno do chamado "fantástico contemporâneo" (ou neofantástico, ou realismo fantástico, ou realismo mágico, ou realismo maravilhoso). Por agora, no entanto, a questão é outra: alguns engenhos em Rubião potencializam um horizonte de pensamento que promove reflexões sobre a noção de não-senso (não-significado). O não-senso é uma possibilidade, por assim dizer, "transgenérica" - ainda que por vezes possa ser decidido em melhores circunstâncias no que se convencionou chamar, genericamente, "literatura nonsense", "literatura do absurdo" e mesmo "literatura fantástica". A fim de fazer jus a este horizonte, esta dissertação cruza os contos, animada por uma "lógica do acontecimento", buscada fora das tradições platônicas e aristotélicas, criando ao longo dos capítulos cenários e instâncias associativas que, por sua vez, solicitam algumas distinções: explicação laboratorial e experiência lógica, sensosignificado e senso-sentido, imagem e imagem pura, "ser" e "extra-ser". A discussão aqui travada visa contribuir para a prática de uma experiência na literatura de Rubião.

Palavras-chave: Murilo Rubião, Não-Senso, Figural, Imagem Pura

ABSTRACT

Murilo Rubião is seen as a rare case in Brazilian literature: few authors have produced a fiction so strongly marked by unusual situations, strange events, and unusual scenes. Not for nothing, his literature is studied starting by discussions on the so-called "contemporary fantastic" (or neo-fantastic, or fantastic realism, or magic realism, or marvelous realism). For now, however, the question is another one: some of Rubião's pyrotechnics empower a horizon of thought that promotes reflections on the notion of nonsense (non-meaning). The nonsense is, so to speak, a "transgender" possibility - though sometimes it can be determined, in the best circumstances, in what is generically called "nonsense literature", "literature of the absurd", and even "fantastic literature". In order to make justice to this horizon, this dissertation travels the tales, it animated by a "logic of the event", outside of the Platonic and Aristotelian traditions, creating, throughout the chapters, sceneries and associative instances which, in turn, ask for some distinctions: laboratorial explanation and logic experience, sensemeaning and sense-sense, image and pure image, "being" and "extra-being". The discussion promoted here aims to contribute to the practice of an experience in the literature of Rubião. 
SUMÁRIO

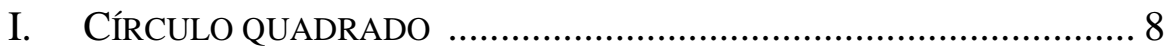

II. O D-EFEITO RUBião ............................................................ 15

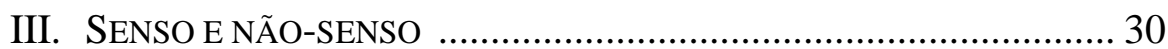

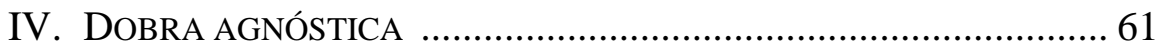

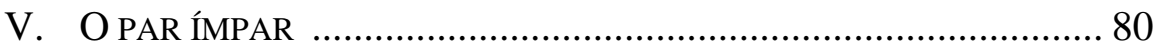




\section{I - CÍRCULO QUADRADO}

Estranho é o pensamento crítico destinado a "explicar", especialmente quando sob esta provocação prévia que o objeto potencializa: o insignificável, o impensável, o indizível. Toda proposição pretende ser de um tipo superior àquela que lhe serve de objeto, vinculada à possibilidade de enunciar um segundo discurso sobre um primeiro, supondo-se que o segundo diga precisamente o que já estava no primeiro. Mas, se se tem a proposição-objeto como um não-significado, as duas proposições já não podem ter uma relação tão simples: o não-senso primário instala sua soberania exigindo certo não-senso secundário. Daí que não se deva falar de "explicação", mas de experiência: substitui-se, pois, uma "lógica da verdade" por uma "lógica do acontecimento", definida como um devir ilimitado. Essa experiência em literatura (que se vê, por exemplo, de formas muito diferentes, em Bachelard, Blanchot, Foucault, Deleuze ou no último Barthes) está distante de tradições rigorosamente hermenêuticas (na medida em que estas lançam um olhar reflexivo sobre o objeto para apreenderem significados com supostas validades gerais) e desempenha um valor particular: experimentar é estabelecer a relação com um impensável, mas um impensável que não é místico nem está para além da experiência, que está sob a forma de um acontecimento inexpiável ou indemonstrável, que fomenta exatamente a lógica dobrada, redobrada e desdobrada pela qual a experiência retorna a si mesma e se efetua: dobras sobre dobras. Portanto, na experiência, o que desenvolve envolve: as proposições têm validade pragmática na dinâmica ou no deslizamento da própria experiência - e não como verdade universal. Ora, em Murilo Rubião se encontra algo condizente com o nível da experiência: o laço da fantasia com aquele espaço inefável da própria fantasia, insistente, subsistente; uma espécie de fantasia "quântica", que se faz no simultâneo, no incerto, no aleatório, no acaso, no impensável. Tal fantasia pirotécnica pode ser decidida como não-senso (não-significado), definido aqui, logo, não como "absurdo" ou “ilógico", mas como algo intangível - o que faz repensar o próprio estatuto da interpretação (possibilidades e limites). Assim, a pirotecnia introduz uma lógica alógica: apresenta-se fazendo valer aquilo que, do ponto de vista da experiência, não pode se manifestar senão como a mais radical ultrapassagem da demonstração laboratorial. Pense-se conceitualmente: a pirotecnia como um não-significado, engenho denominado imagem pura, em que a leitura já não deve se definir como um processo cuja meta seja descobrir, criar ou atribuir significados. Implicaria dizer: nalguma fantasia rubiana, não se deve buscar um significado solene nem uma pluralidade de significados; deve-se ver o ato em superfície, a impenetrabilidade do 
extra-ser, o campo do indizível. Está-se pensando, é claro, somente em alguns contos - num dos horizontes de pensamento potencializados por eles (contos que são, pois, o que o força, na destinação que é a sua própria, no exercício da sua potência). Teoricamente, é preciso admitir a possibilidade da assemia no engenho. Pois há pelo menos duas maneiras de tratar pragmaticamente uma pirotecnia: torná-la sempre significativa, por meio de infindáveis atribuições de significado, ou apenas tê-la como uma zona de indiscernibilidade, respeitando a sua forma bruta. No primeiro caso, entenda-se algo vinculado à ideia de que a pirotecnia precisa ganhar necessariamente algum significado ou no mínimo ser vulnerável a vários significados - sim, muitas vezes sob a compreensão mais organicista da ideia aristotélica de verossimilhança (a despeito de leituras moderníssimas e modernizantes, verossímil como aquilo que é semelhante à verdade, ligado ao campo das possibilidades externas, aos conceitos universais e gerais, que proporciona certo desvendamento da realidade em função do seu significado possível). Está aí a premissa de que mesmo uma proposição pirotécnica é um signo e que, por essência, não pode haver signo sem significação, significante sem significado. No segundo caso, tem-se a leitura reduzida ao respeito: inútil. Talvez, uma ascese: decidir e suportar o não-senso irredutível, diretamente sem a mediação do "pré-texto" (proposições primárias) ou do "pós-texto" (proposições secundárias), no silêncio da imaginação. $\mathrm{O}$ experimentum agora se satisfaz com uma dimensão sigética ${ }^{1}$ : aquilo de que se tem experiência se torna um experienciável na experiência e um inexperenciável na explicação. Está aí a premissa de que uma proposição pirotécnica pode ser absolutamente uma proposição pirotécnica, nela, sem significação. Substitui-se, assim, na apreensão dessas duas maneiras, a questão da "origem" pela questão da produção (a significação e a não-significação como coisas pragmaticamente fabricadas) e a questão do "verdadeiro" pela questão do acontecimento (a escrita pirotécnica como fluxo para uma experiência lógica, não como código para uma explicação laboratorial). Poder-se-ia considerar o princípio de verossimilhança interna como um aspecto relevante, embora Aristóteles critique o uso do irracional no poético (não deveria ser usado, preferível seria que nada houvesse de irracional): um mundo em si (incoerente, coerentemente), formas internas com leis próprias, ainda que impensáveis em relação ao que se tem externamente como realidade - da mesma maneira que se diz, assim, aristotelicamente: são preferíveis as coisas impossíveis e críveis às possíveis e incríveis. Todavia, pense-se, desde a geometria não-euclidiana, a teoria da relatividade e a

\footnotetext{
${ }^{1}$ Sigética (al. sigetik, a partir do gr. sigan: “permanecer em silêncio, calar”), termo introduzido por Heidegger que designa a ciência ou a arte do silêncio, incluindo a dimensão do vazio. Ao predominantemente glóssico e sígnico do pensamento ocidental, o pictural ou o sigético.
} 
física quântica, que inauguraram outro olhar sobre o mundo ao romperem com a ciência clássica, nem mesmo se pode determinar com segurança um parâmetro pelo qual o "possível” e o "impossível" se definam. Por "ato em superfície" se entenda os acontecimentos puros, o engenho de histórias que perturbam os nexos de alturas e profundidades (por exemplo, ausência daqueles nexos de nós definidos, ou de intensos raios x sobre uma peripécia, ou de fortes peregrinações psicológicas, ou de densas fabricações de um clímax), o engenho de histórias soltas que destroem clichês e associações estereotipadas (ausência daquele "isto, nisto"), o engenho de histórias que podem levar o leitor a lê-las literalmente e a imaginá-las fluida e silenciosamente de outro modo (mais um, depois de mais uns, mas apenas no verniz das coisas) e, especialmente, o engenho de lógicas alógicas que podem ser decididas como não-senso (fora das redes de significado). Quem não pensa sobre a possibilidade da potência intransitiva da pirotecnia sempre busca significados, recaindo às vezes na ideia de que certa verdade profunda suplanta o tecido licencioso; mas Rubião inventou máquinas de fantasia que não têm segredo algum além da visível relação da fantasia em si; nela, jaz o que constitui mesmo a fantasia, quer dizer, seu vazio, não a plenitude de um significado oculto: à pura identidade se contrapõe uma invenção insolúvel; à pura homologia, uma analogia arriscada; à pura definição, uma análise indeterminada. De qualquer forma, há um processo de dificultar as redes, de recolher o dedo indicador, que reclama, nesse caso, não exatamente uma interpretação empenhada em significados (monossemia ou polissemia), mas uma experimentação dos fluxos indeléveis da assemia, cujo potencial disjuntivo proponha, aqui, acolá, algum conjunto de constelações-problema. ${ }^{2}$ Nos capítulos seguintes, vê-se assim: em “O d-efeito Rubião", uma apresentação geral das pirotecnias rubianas, por meio de paráfrases e comentários de alguns contos (trata-se de uma introdução); em "Senso e não-senso" (capítulo que parece ser o mais necessário) e em "Dobra agnóstica" (capítulo suplementar), o conceito de não-senso a partir da ideia de imagem pura, em determinados contos e nas epígrafes bíblicas, distinguindo senso-significado (dimensão atual) e senso-sentido (dimensão virtual); em "O par ímpar", enfim, as personagens do não-senso, entendidas como entes do pensamento impensável, extra-seres, tomando como exemplo o caso do vivo-morto. Nessas linhas, a ênfase geral no não-senso se limita, pois, a uma experiência com algumas pirotecnias. Tal disposição programática pode ser entendida como um jogo de xadrez: uma dimensão virtual (o xeque: a questão do não-senso) é continuamente atualizada por uma dimensão atual (o movimentos das peças: os capítulos e os parágrafos, com as suas diferentes

\footnotetext{
${ }^{2}$ Uma distinção muito sucinta de monossemia, polissemia e assemia pode ser encontrada em Roland Barthes, "Uma problemática do sentido" (1956), in Inéditos, I: teoria, São Paulo: Martins Fontes, 2004.
} 
maneiras de experiência). Nisto, pode-se escolher uma língua crítica inventariante no que se permite inventariável (no registro de opiniões sobre a prosa rubiana, por exemplo) - um conceber-se e um fazer-se, com claras subordinações, medidas, sentenças. Mas sob o engenho mais bruto dos textos literários, sob os problemas de toda ordem que eles apresentam, escolhe-se já outra língua: discorrer sobre o não-senso, o intransitivo, o indizível, o intraduzível, exige uma língua crítica que busque, suporte e afirme a lógica do impensável, que faça proliferar as experiências do pensamento, cujo caráter polimórfico conceda espaço aos instantâneos, que atente para a diversidade como um elemento necessário, que sorva as miríades de detalhes da sensibilidade, que imagine e convide à imaginação, à deriva, usando, inclusive, diversas nomenclaturas para as mesmas coisas (isto, em vez daquela busca por uma interpretação "legítima" a se hospedar naquela língua crítica bem comportada cuja ilusão é pôr-se útil, clara, objetiva, e crer-se decifrando). A crítica, aqui, procede então à maneira da atual física-quântica, contentando-se em fazer aflorar ao nível da experiência os diferentes estratos acumulados, justapostos, não sem lutas intestinas, em localizar descontinuidades e rupturas que afetam a sua própria sedimentação: ora o estilo vai se estrangular, atar-se para emitir as sufocações do não-senso, nas rapidíssimas sacudidas da imaginação; ora será entrecortado pelo equilíbrio do mais rigoroso raciocínio, em bases teóricas. Que esta literatura seja propícia a algum pensamento lábil é fácil de entender: Rubião pratica a fantasia da fantasia, ora imprevisível, ora muda, perturbada sempre pela intervenção do aleatório, pela irrupção do inteiramente Outro, o maldito da razão, que se revela apenas em seus ardis. É o caso: faça-se, no tom, no modo de observar, pelo menos por vezes, alguma encenação ou dramatização dessas coisas - como que a reproduzir no pensamento crítico o horizonte de pensamento potencializado pela própria flutuabilidade de um encontro objeto-leitor. Implica, é claro: não pensar simplesmente por rótulos, definições ou classificações, transitar nas modalidades de pensamento forçadas pelo encontro. Tal outra língua não tem senão um propósito: falar de Rubião rubianamente, uma forma de experiência cujos princípios são determinados, desde o início, pela sua própria natureza experimental, no privilégio de seu objeto, mas em redes intercomunicantes, elétricas.

Para se falar do não-significado em Rubião, deve-se atualizá-lo, antes, com uma noção de significado. Mas sabe-se: em qualquer caso ou situação, um simples resvalar nas questões relativas ao significado se torna ocorrência problemática, como se resguarda Greimas já na introdução de Du sens: "É extremamente difícil falar do sentido e dizer alguma coisa 
significativa". 3 Existem inúmeras acepções: o assunto é imponderável e insolúvel (uma mínima tese sobre ele seria hoje impossível); a história do pensamento ocidental sempre foi dominada por uma tensão e uma contradança entre as teorias do significado e as teorias do signo. Assim, não é necessário dizer, mas se diga, de antemão, com muitíssima ênfase: a questão tomada em Rubião não visa produzir uma teoria geral sobre o problema do significado ou do não-significado; ela assume aqui somente a forma de uma criação orientada, limitada, breve, reduzida, vista e revista a partir de alguns poucos contos - numa perspectiva de abordagem previamente traçada. Faça-se já, então, um pequeno, mas necessário, mapa introdutório, que é a geografia escolhida, não mais do que uma premissa pela qual se dará a experiência em Rubião: não um "como é” universal (explicação ou ortodoxia teológica), mas um "como é aqui" (experiência lógica, que é um devindo). Significado é um conceito-limite, geralmente equiparado a uma modalidade forte e incisiva do pensamento que é o querer dizer ou poder dizer. Afirma-se, comumente: grande parte da organização de um texto reside na moldagem de significados; os padrões em literatura são padrões de significado e, inversamente, os significados em literatura são significados de padrões; assim, o estudo do texto literário fica intimamente ligado à significação. Quando se considera um fenômeno, como fez o estruturalismo nos anos sessenta (performances de fala para os linguistas, sonhos sintomáticos para os psicanalistas, regras de parentesco para os antropólogos etc.), toda a questão é saber como é possível produzir significados. Compõem-se aí duas figuras dóxicas: a do "bom senso" (bom sentido ou boa direção), que classifica tudo à maneira da coerência, do mais ao menos diferenciado, distribuindo e encadeando as coisas em suas relações, e a do "senso comum" (sentido e juízo), que identifica e estabelece cada coisa a partir de faixas domesticadas em um ponto referencial. Ambas as figuras desempenham papel capital na atribuição de significados. As operações de significação podem ser reconhecidas pelo fato de que compõem blocos referenciais e rotulados, disponíveis para quase toda operação ideológica, e só entram em disputa umas com as outras para modelarem, todas juntas, a título de “descoberta”, uma espécie de consenso arrumado. Mas é razoável afirmar que, em qualquer expressão, nunca se faz conhecer ao mesmo tempo alguma coisa e seu significado, isto é, nunca se diz simultaneamente o significado do que se diz: exprime-se apenas proposição (no recinto da palavra, da frase ou do discurso), de onde se depreende imediatamente uma espécie de nuvem de significações, ligeiríssimas operações de paráfrase ou de transcodificações, em que o significado de uma proposição se acha afinal num processo

\footnotetext{
${ }^{3}$ Algirdas Julien Greimas, Sobre o sentido: ensaios semióticos, Petrópolis: Vozes, 1975, p. 7.
} 
de relações: uma proposição implica outra, cujo significado, por sua vez, será objeto de uma terceira - e assim por diante, proposições sobre proposições, nas quais, pela elasticidade dos jogos semânticos, nenhum dicionário oferece termo. O assunto é arcaico: Ricoeur lembra que, muito antes da linguística moderna, em Platão, no Crátilo, no Teeteto e no Sofista, já se encontrava não decidido o "problema da verdade" das palavras isoladas, dos nomes, da frase, tendo então que uma denominação não poderia jamais esgotar o poder ou a função da fala. ${ }^{4}$ Obviamente, as velocíssimas operações de significação dependem de proposições-objeto, assim como proposições-objeto dependem de proposições anteriores: como em redes móveis ou circuitos elétricos plurais, proposições secundárias são construídas conforme uma multiplicidade de encadeamentos possibilitados por proposições primárias. Aquele que se aproxima de um texto já traz uma pluralidade designativa, repertoriada por proposições acumuladas, códigos culturais, convenções éticas, condições ambientais ou situacionais. $\mathrm{O}$ significado, assim, nunca é princípio ou origem: é produto flutuante. Nada significa em si e é absolutamente inocente a ideia de que a significação se acumula como um achado final; com efeito, uma proposição nunca encontra derradeira tradução: sua natureza é um proliferar-se indomável (embora, paradoxalmente, como meio de comunicação, clame por um momento em que possa se tornar domável). Compõe-se, deste modo, o móvel do significado, que nunca é monógamo, que se desloca em relações proposicionais infinitas, tal como se conhece a proliferação das entidades verbais pelo chamado paradoxo de Frege. ${ }^{5}$ Sendo um processo plural e móvel, a significação se constitui como "promessa", cada momento dela sendo apenas uma demonstração de promessa (colheita provisória, jogos de verdade), despedaçando-se nas multiplicações irregulares das direções, não definitivas, incluindo o livre curso de interrelações; ou seja, ela fundamenta a verdade tornando o erro ao mesmo tempo possível e, assim, frustra a ideia de que um leitor, ao se aprofundar na especulação sobre os significados de um conto, por exemplo, possa ficar cada vez mais perto da verdade: para o jogador eterno, que lança a moeda uma infinidade de vezes em senso-significado, "coroa" cai tantas vezes quanto "cara", pois nenhuma decisão é primeira ou última, todas as decisões se comunicam e passam umas para as outras: eis o caráter infinito e irrestringível da significação. Vê-se, de qualquer forma, a relação de dependência: uma proposição literária, a princípio, não tem mais do que uma existência literária; porém, esta existência deve se passar nas interpretações como

\footnotetext{
${ }^{4}$ Cf. Paul Ricoeur, Teoria da interpretação: o discurso e o excesso de significação, Lisboa: Edições 70, 2011, p. 11.

5 A ideia fregeana é a de que as proposições têm um significado e uma referência, mas toda palavra que designa um objeto se torna sempre objeto de outra palavra que designa seu significado, incessantemente. Cf. Gottlob Frege, "Sobre o sentido e a referência", in Lógica e Filosofia da Linguagem, São Paulo: Cultrix, 1978, pp. 59-86.
} 
que dependente de outra existência, a do intérprete, submetida a deliberações racionais, subordinada a conceitos julgados universais e sólidos, à contradição verdadeiro e falso, à caução imperiosa do "real", na qual não há processo linguístico desprovido de significação mesmo na insignificância, infinitas significações. Está aí: a impossibilidade de conceber uma zona de linguagem independente da pragmática. Mas o que é então o não-senso? Se um professor pede às crianças que desenhem um círculo, elas desenham um círculo. Se ele pede que desenhem um quadrado, elas desenham um quadrado. Se enfim pede que desenhem um “circulo quadrado" - é incrível - elas também tentam desenhá-lo no caderno: não raramente, rabiscam uma figura mista e engraçada, meio redonda, meio quadrada. Por serem crianças, ainda não se dão conta de que, como operação lógica, ali insiste ou subsiste uma dimensão de pensamento impensável - algo que não deve ser desenhado, transmitido, dito, traduzido, significado. Tem sido este o problema vital da crítica que só pensa em termos de significação, no Império da Significação, sendo o ocidente tributário apenas de uma filosofia do ser, platônica e aristotélica, e não de uma filosofia do extra-ser. A esta crítica, já é possível afirmar, pelo menos inicialmente: o não-senso é a Coisa que não deve (embora possa) ser substituída por outras coisas, o deixado como tal, o fluxo visto pragmaticamente como autônomo, o $x$ que só é $x$, o vazio, o simulacro não submetido às formas do inteligível, aquilo que exige certo não-senso crítico quando tomado por intangível. ${ }^{6}$ Se a significação é uma decisão pragmática que, pela altura ou pela profundidade, efetua-se numa "puríssima eliminação do indizível”, , o não-senso é uma decisão pragmática que, pela superfície, efetuase numa puríssima aceitação do indizível. Enfim, as pirotecnias não contradizem a "realidade" nem a "irrealidade", mas a lógica; porém, não exatamente “a lógica", mas a lógica demonstrativa, laboratorial, corporal, conforme instituída pela filosofia do ser: solicitam outro tipo de lógica, uma lógica alógica, um trânsito no extra-ser. Como escreve Foucault, pensando na filosofia estoica do extra-ser e especialmente na teoria do sentido de Deleuze: "É toda essa pujança do impalpável que é preciso pensar hoje: enunciar uma filosofia do fantasma que não esteja, por intermédio da percepção ou da imagem, a serviço de um dado originário". ${ }^{8}$

\footnotetext{
6 Não é em termos absolutamente diferentes que o Japão de Barthes se faz em L'Empire des signes: desembaraçado do significado, esvaziado das formas ocidentais de identificação com um conteúdo. Cf. Roland Barthes, O império dos signos, São Paulo: Martins Fontes, 2007.

${ }^{7}$ A expressão é de Walter Benjamin, em sua conhecida carta a Martin Buber, datada de Julho de 1917, conforme citada em Giorgio Agamben, Infância e história: destruição da experiência e origem da história, Belo Horizonte: Editora UFMG, 2005, p. 11. Para Benjamin, tal "puríssima eliminação do indizível” significa superar o que ele entende por "místico".

8 Michel Foucault, "Theatrum philosophicum" (1970), in Arqueologia das ciências e história dos sistemas de pensamento (Ditos e escritos - vol. 2), Rio de Janeiro: Forense Universitária, 2008, p. 233.
} 


\section{II - O D-EFEITO RUBIÃO}

E se a fantasia não implicasse algum significado solene? E se ela nem sequer implicasse significados, servisse apenas à imaginação, absolutíssima? Se ela não fosse um segredo a ser desvendado nem o mais além a lhe ser atribuído, mas justamente um novelo embaraçado em torno de si mesmo, o fictício somente, cárcere e horizonte de efeitos simultâneos, efeitos completamente realizados em seu solo de motivos vãos? Decidida como não-senso, saltaria aos olhos em estado bruto, ilegível, bem ou mal, como loucura ou delírio, ao lado, pouco à retaguarda, diagonal a um tino mínimo, entre o pensável e o impensável: convite a se alimentar dela, nela - não no que ela poderia significar, mas no seu hiato, no seu Zero. Aí, um projeto sem hastes, destituição das profundidades e das alturas, apenas superfícies, um ao longo de, como um brilho de verniz. Para repetir Paul Valéry: na pele, paradoxalmente, o mais profundo. Em "A casa do girassol vermelho", as "pétalas" sem simbolizar algo; em "O pirotécnico Zacarias", o "branco" intransitivo, indizível, figural; em "A flor de vidro", a "flor", uma intraduzível Coisa-flor. O que seria ela senão a simples fantasia em si, o agora sem antes nem depois, o já sem o ainda não, o singelo do incomunicável, a mais fina película da planície? Rubião em Rubião: fantasia pirotécnica, evidentemente. Uma apresentação: deve-se pensar numa escrita simples e enxuta, levíssima, na maioria das vezes quase nômade entre a graça e a delicadeza, e numa fantasia-bestice poderosíssima. Tal qual aciona músculos suficientemente bisonhos - e por isso mais livres - para enredar o que ela mesma faz verter, busca motivo em situações dissonantes, embora historicamente persistentes no domínio da literatura - metamorfoses, zoomorfismos e cromatismos, por exemplo. Dragões têm aparência dócil e meiga, chegam a conviver com seres humanos; ninhadas de filhos ocupam totalmente o espaço de um quarto, do chão ao teto; à beira da praia, coelho conversa com homem. Visagem, consolida-se imponderável; fantasia que reclama subtrações como adições, incoerente; que aí se vê no seu desconcerto, pois efetua dissolução de significados gregários, indeterminações: aventuras que transitam deliciosamente entre enquadramentos adversos, situações que transgridem o convencional, narradores que sustentam o indizível, personagens que ultrapassam o explicável. Mesmo os elos que conciliam as disparidades entre o já-visto e o nunca-visto podem figurar como elementos subjacentes, escusos, interditos ao uso ordinário da linguagem; pandemônios, podem se arrumar na ficção numa constituição ambígua e relativa, de onde somente é possível acolher caracteres múltiplos, volúveis, declináveis - ou indeléveis. Fantasia que se inclina a desenlaces quase cataclísmicos, desfechos implacáveis, 
como metáforas agudas, na criança encardida, sem dentes, que Teleco enfim se transforma, em Alexandre Saldanha Ribeiro emparedado (um, dez, cem, mil anos), na nulidade última de Gérion, na bolinha negra rolando na mão de Roderico, mas que evita iluminar a dimensão de seus efeitos. Talvez permita apenas um paradoxo: pulverizar-se em muitas parcelas de significados possíveis, inseguros, instáveis, provisórios, e, ao mesmo tempo, como um "dito" autônomo que se reveste de "não-dito", fechar-se absolutamente, como não-senso (os significados inexistindo: nada sendo decidido como condição de verdade; nada além dela mesma, fantasia da fantasia da fantasia): ela, aderente à meta desejada, forçando com poetices todos os limites do que se supõe "símbolo". O leitor começa a ler e cai no embuste, tom menor que se impõe aos poucos, por insidiosa sedução. Poderá, assim, conservar-se algum tempo sob a injunção bélica que é inerente ao seu ato (recusar, revolver, resistir), até que se entregue e se integre de vez à maquinaria, aos dispositivos. Também por causa do colarinho, epígrafes bíblicas encimando todas as trinta e três narrativas, vagueará entre gravidade e leveza, alturas e larguras, detido de algum modo numa percepção confusa e contraditória, até poder decidir que nessas narrações líricas e coloridas pode estar contida alguma coisa não apreensível, indemonstrável, alógica: complexa e alérgica à interpretação, uma espécie de fantasia "quântica". Verá então que o determinado depende do determinante, que as designações de supostas leituras subtendem e revelam pragmaticamente os seus próprios pontos referenciais (Hans-Georg Gadamer sobre o fenômeno da pré-compreensão: a implicação inevitável dos efeitos em que a própria consciência interpretante, histórica, está enredada) e que a fantasia-bestice, especialmente naquilo que ela apresenta como a mais radical de todas as pirotecnias, tomada então como imagem pura, permite todo um incontornável experimentum sigético.

Perto de derradeiras imagens apocalípticas, menos plena, contudo, do que aquele brilho da nova Jerusalém, com o rio claro como cristal e a árvore da vida que produz doze frutos, fantasia, por exemplo, de um quintal-jardim onde, sob os caprichos de um desconhecido, poeta, homem de nariz grosso e curvo, com cabeça desproporcionada, quase do tamanho de uma janela, o narrador José Ambrósio, jornalista de plantão noturno, expurga a impotência à criação de texto: aparecem lá os versos (sem escrita), os primeiros cantos, feitos apenas de rosas despetaladas; mas ainda "falta o girassol". Anuncia-se, então, pelos sons de trombetas sopradas por padres capuchinhos, pelos pistons agudos da Filarmônica Flor-de-Lis, pelo coral dos homens de caras murchas, a chegada triunfal de Marina, a Intangível, que vem vestida de 
cetim amarfanhado, num andor, escoltada por padres sardentos e mulheres grávidas, empunhando na mão direita um girassol. Este querer-escrever implica um ver que implica um não-dizer: as noções grandiosas e extraordinárias que alternam uma situação ordinária de jornalista, que na sua superacumulação pictórica, de sugestão "neobarroquista", assimétrica, excessiva, quase como num Rubens ou num Caravaggio, preenchem o noturno da "redação", são um modo incontido de fantasia alquímica: mentira que vai além da mentira que a fícção já é, mas que mente sem mentir sobre a sua própria irregularidade. Mesmo o imaginário da tradição religiosa, alheio aqui à sanção de um dogma, no protagonista que abre a Bíblia e balbucia livremente uma oração para cumprir a tarefa da escrita ou no cenário estranho que depois se compõe, reveste-se, imaginário macaqueado, de uma liberdade feroz e feliz que dificulta as redes de significado. O resultado é a confrontação do leitor com uma história que, para lá de inverossímil, substitui as soluções e os códigos fixos ou identificáveis pelos "fluxos" e pela indeterminação - trombetas, pistons, coral, mulheres grávidas. O fato de que um eixo mínimo de problema (não escrever, escrever) tenha sido encerrado desta forma, sob uma invasão de seres inusitados, não estabelece, vê-se, uma relação de homogeneidade ou filiação, ou de autenticação, ou de explicação recíproca, ou de utilização concomitante: força, manipula, intermite, continuamente, interpretação e des-interpretação. O conto fica, por assim dizer, mosqueado de torpor irresoluto; sobretudo, querendo a precedência das imagens sobre a mensagem, do imagético sobre o discursivo. O leitor convencional (e convencionado, pois ideológico desde aí) resiste, desiste; afinal, suporta tudo, menos a falta de algo razoavelmente discriminável nesta escrita discretíssima.

Numa entrevista a Granville Ponce, o autor tenta explicar: "Usando a ambiguidade como meio ficcional, procuro fragmentar minhas histórias ao máximo, para dar ao leitor a certeza de que elas prosseguirão indefinidamente, numa indestrutível repetição cíclica". ${ }^{9} \mathrm{~A}$ explicação do autor, é claro, refere-se às potencialidades não aprisionadas nas histórias. Em "A armadilha", Alexandre sobe as escadas de um prédio inabitado carregando uma volumosa mala - está voltando de viagem; no décimo andar, encontra um velho que está a sua espera, imóvel, apontando-lhe um revólver. Apesar das projeções de suspense e do assassinato inserido como possibilidade, o narrador informa que para Alexandre tal encontro é uma circunstância inadiável: Também a Alexandre não interessava fugir, porque jamais perderia a oportunidade daquele encontro. Diz então o homem: - Afinal, você veio. [...] Há dois anos, desta cadeira, na mesma posição em que me encontro, aguardava-o certo de que você viria. $\mathrm{O}$ encontro poderia estar vinculado

\footnotetext{
9 J. A. de Granville Ponce, "Entrevista - O fantástico Murilo Rubião", in Murilo Rubião, O pirotécnico Zacarias, São Paulo: Ática, 1998, p. 4.
} 
ao "caso Ema", caso único, trazido rapidamente à conversa, tornar-se assim transitivo, feito um acerto de contas - no que esses "dois anos" de espera, "na mesma posição", poderiam ser entendidos como apêndices de uma operação simplesmente retórica. Mas apenas se disfarça aí: não está associado à figura feminina. Mostra-se indefinido. De qualquer forma, o pior: o homem não pretende matar Alexandre; guarda a arma descarregada, fecha a porta, joga a chave fora, em pleno cálculo: - Aqui ficaremos: um ano, dez, cem ou mil anos. As janelas fechadas com tela metálica, que não tornam possível o suicídio, a porta de aço cerrada, que não permite a fuga, e o prédio sem empregados ou inquilinos, que não viabiliza o pedido de socorro, impedem um fim para a situação. Todas as saídas estão aferrolhadas. O desfecho revela uma feição ardilosa: um perpetuar da noção de experiência e uma subdivisão dentro da noção. A experiência indica uma ação que se lança a um moto-perpétuo (ficar), mas sinalizando gradações temporais (um, dez, cem, mil anos), o que a torna mais terrível. Eis que a decisão nociva é elevada, por porções, à enésima potência: assim como enclausurar, na situação, é mais "maligno" do que matar, dispor o tempo em graus, esmiuçá-lo, antecipar o seu movimento por gradação, deixar nítido que ele avançará passo a passo, em linha, é aqui mais "maligno" do que um explícito eternamente. Enquanto o conto se depõe em forma cíclica (um fim sem fim, para dar ao leitor a impressão de que prosseguirá indefinidamente), as personagens ingressam nesta espécie de labirinto que não é um círculo nem uma espiral, é um labirinto em linha reta (pior do que o circular), do um ao impensável mil anos, um fio, onde é impossível fugir ou se perder, tanto misterioso quanto simples, inexorável (lembra o conto "A morte e a bússola" de Borges: "prometo-lhe esse labirinto, que consta de uma única linha reta e que é invisível, incessante"). É fantasia do inumerável, do interminável, e ao mesmo tempo dos gestos estancados, satisfeitos; história feita para morrer e renascer das próprias cinzas, propositalmente truncada; história que, extremamente paradoxal, decreta e in extremis suspende a própria morte (como se disse, "indestrutível repetição cíclica”).

Obscuro, quase nada evidente: livre e mordaz, efeitos de superfície, de verniz. Os caminhos das narrativas são às vezes inescrutáveis, privilegiando silêncios, banalidades, detalhes, razões insondáveis. À pergunta “do que se fala?" se aventura o prazer ou o desprazer do leitor. No conto "Epidólia", por exemplo, existe apenas a evidência de um desaparecimento instantâneo, que não deixa vestígios, que requer uma busca: Olhava para os lados, atônito, até render-se à evidência do desaparecimento da moça. O braço de Manfredo, solto, estendido sobre o encosto do banco, ainda conserva o calorzinho dela. Dá-se o deslocamento ziguezagueante da procura: no Hotel Independência, nenhum sinal efetivo de Epidólia, apenas 
uma calcinha manchada de sangue ainda úmido; nos botequins da orla marítima, o encontro com Pavão, velho marinheiro, tipo depravado, com longas barbas acinzentadas (nelas, moedinhas de ouro a tilintar a cada movimento), e o bate-boca, a briga fútil; na casa do pintor, retratos de mulheres nuas, conversa vã; na Farmácia Arco-Íris, potes com os nomes dos medicamentos gravados a ouro, algum embaraço sobre a suposta virgindade da sobrinha. Do que se fala? Nada é evidente, apenas um eixo mínimo. No que se conta, sempre uma referência estranhamente inócua, ou sobras, ou adornos, ou quebras, ou deslize de coisas, ou gratuidade, ou papagueamento, dir-se-ia, "sem nexo" - variando em cada conto. Aventura-se o leitor, porém, mesmo assim sem corrimãos, guiado pelo jogo ignoto. Em “A lua”, a espreita, a atalaia, o narrador que vigia nas ruas, de longe, os passos de Cris. Um dia, aproxima-se finalmente, saca um punhal, num momento, mergulha-o nas costas dele: Do seu corpo magro saiu a lua. Pura violência ou êxtase? As histórias propõem certos temas, mas terminam quase sempre num instante tênue, anuviado, excessivamente glorioso ou esquisito. Neste, a lua que sai do corpo de Cris (uma lua em eclipse, uma lua cris) e é agarrada por uma meretriz que passa, seu pranto convulsivo, a lua depois desatada que então vai varando o espaço, o rosto infantil de Cris, seu "sorriso de massa". Naquele, Manfredo enfim na parte velha do porto, seguido por um cortejo de homens e mulheres, moços e velhos, unidos todos em uníssono grito: Epidólia, Epidólia, Epidólia.

Noutro conto: Anatólio, o "homem do boné cinzento". Roderico (o narrador) e Artur (o irmão do narrador) observam os preparativos de chegada do novo vizinho: os caminhões de mudança, os pesados caixotes, a mobília que ocupará o prédio do antigo hotel, muitos volumes empilhados na espaçosa varanda do edifício. Anatólio chega, poucos dias depois: usa um boné xadrez, cinzento e branco (nunca aparecerá-desaparecerá sem ele), e traz entre os dentes escuros um cachimbo curvo; tem olhos fundos, sua roupa sobra em seu corpo pequeno, puxa pela mão "um ridículo cão perdigueiro". Artur precipitara os acontecimentos, antes da chegada efetiva do novo vizinho, "ao sabor de exagerada sensibilidade", conta Roderico, a respeito das impressões prévias do irmão: Nervoso, afirmava que as casas começavam a tremer e apontava-me o céu, onde se revezavam o branco e o cinzento. (Pontos brancos, pontos cinzentos, quadradinhos perfeitos das duas cores, a substituírem-se rápidos, lépidos, saltitantes). Os dizeres, é claro, remontam ecos, alusões, hóspedes, fantasmas de outros contos: o desenho coordenado da experiência por meio de cores ou a visão de coisas, pontos, formas, como se vê de maneira semelhante em "O pirotécnico Zacarias"; a caracterização de um tempo-movimento sempre rápido e lépido, como se vê nos anos ágeis e lépidos de Marialice, em "A flor de vidro"; o vestígio celeste, agora em branco e cinza, dos astros congêneres, azuis, verdes, amarelos, rubros, que Og teima 
em ver no céu, em "Bruma (a estrela vermelha)". Há sempre este repisar visionário em Rubião, constante e pirotecnizante, mesmo no âmbito das palavras: alenta-se na repetição desses modos e aplicações, que é hóstia de seu engenho frívolo. Roderico, a princípio, assume uma atitude zombeteira ante a "figura grotesca" de Anatólio, enquanto Artur fica transtornado, profetizando: - Esse homem trouxe os quadradinhos, mas não tardará a desaparecer. O xadrez do céu, o xadrez do boné - eis a indubitável lógica do pensamento impensável. Nela, tudo é ao mesmo tempo afim e remoto - assim, pista frágil, nebulosa. A sua plástica imaginária não é senão a forma de um paradoxo: o pensável e o impensável. Os quadradinhos perfeitos de duas cores no céu são um princípio adjacente aos quadradinhos do boné que cobre a cabeça de Anatólio? São de fato uma antecipação imagética da sua chegada propriamente dita? Podem apontar, naquela capacidade de se substituírem rapidamente, saltitantes, por movimentos que revezam o branco e o cinzento, outra natureza de movimento, a do emagrecimento gradual de Anatólio (emagrecimento que também será ponderado pela folga crescente do boné em sua cabeça, até escorregar aos olhos)? Decida-se, assim, sob esta pirotecnia de xadrezes: imagem pura, não-senso.

No mundo "quântico" de Rubião há aleatoriedades, simultaneidades, incertezas, desarranjos: cria-se às vezes esta espécie de d-efeito. Há nas histórias engrenagens, lubrificantes e adstringentes, instantes e eternidades, zonas geladas e quentíssimas, nunca moderadas - embora, obviamente, elas não sejam iguais em fantasia nem tenham sempre a mesma intensidade: toda a arte de manobra, toda a tática lógica que potencializa um modo de pensar o impensável, escondida às vezes em coisas ligeiras, fáceis, adocicadas. Nelas, o indizível pode atravessar a enunciação das referências tópicas e espaciais correntes, o mar, o barco, o cais, o porto, a estrada, o trem, as flores, as cores, a cidade e seus espaços (casa, rua, taberna, circo, repartição pública, redação de jornal, salões, restaurantes, fábricas, prédios abandonados - dotados de concretude e, simultaneamente, de modos abstratos). Por vezes, existe o drama da expressão que nunca se entrega nem postula um enigma a ser decifrado, certo "efeito de neblina"; pressuposto vital: não são todas as coisas comunicáveis. É um tipo de ficção que parece tolo, primário, sem ser: desarranja certos códigos da cultura crítica, demanda outros modelos de leitura e de leitores; não faz caso do anseio por coerência, recheado que é de marcas insolúveis; não pretende conferir a uma complicação um significado cuja palavra conclusiva possa se tornar o clichê do intérprete; deixa o leitor, por fim, no beco do enigma perpétuo, enquanto tiraniza, pelo "informe" de sua forma, pela "alógica" de sua lógica, a tentação de extrair de seu âmago uma conclusão insofrível. Vê-se já 
que há nas pirotecnias rubianas um horizonte de pensamento para o gesto de experiência extensiva e intensiva da não-significação.

Eis que o movediço Rubião se torna para uns e outros "onírico”, "surreal”, “absurdo", "hiperbólico", “espantoso", "simbolista", "metafórico", “transcendente”, "visionário", "realista", "libertário", "gratuito", "rubiano". Por que esta literatura, tão simples aparentemente, até o ponto em que se pode acreditá-la simplória, revela-se, examinada, proteiforme? O mistério Rubião, o dispositivo Rubião, o fantasma Rubião, a coisa Rubião como dar-lhe um nome? Posto um desafio, aí como um dos casos incomuns na literatura brasileira, tem-se a questão repisada: nele, o que há? Nos anos quarenta, os primeiros leitores, especialmente Mário e Lins, comparam-no a Kafka. ${ }^{10}$ Nos anos sessenta, Candido, quando comenta, em carta ao autor, alguns aspectos dos contos, faz menção a Borges e ao nouveau roman, destacando o Marienbad de Robbe-Grillet e Resnais; depois, nos anos setenta, pensando nas principais produções brasileiras de meados do século XX, destaca como inovadores do período Lispector, Rosa e Rubião - os três, lado a lado, no mesmo ambiente de argumentação: "produziram um toque novo". ${ }^{11}$ Schwartz, Arrigucci, Mourão, Nunes, Lucas e Paes são alguns dos críticos que passam a escrever sobre Rubião. ${ }^{12}$ Surgem trabalhos acadêmicos, ensaios: alguma repercussão. As leituras críticas atuais comumente o colocam no âmbito da "literatura fantástica" - ou melhor, no âmbito do fantástico contemporâneo, considerando diferenças nos vários "fantásticos" produzidos ao longo dos séculos. Fábio Lucas comenta: "O inesperado da linha narrativa do autor [...] encaminhou a crítica a aplicarlhe designativos já gastos, que acabam por não determinar exatamente a natureza de seu relato. Assim, falou-se do uso do 'imaginário` por parte do contista, de seu desvio da prosa realista, do 'fantástico', do 'sobrenatural' e do 'maravilhoso', etiquetas aplicadas a uma

\footnotetext{
${ }^{10}$ Cf. Marcos Antonio de Moraes (org.), Mário e o pirotécnico aprendiz (cartas de Mário de Andrade e Murilo Rubião), Belo Horizonte: Editora UFMG, São Paulo: IEB/USP, São Paulo: Editora Giordano, 1995; Álvaro Lins, "Sagas de Minas Gerais" (1948), in Os mortos de sobrecasaca, Rio de Janeiro: Civilização Brasileira, 1963, p. 265-68.

${ }^{11}$ Cf. Carta a Murilo Rubião, Poços de Caldas, 25 fevereiro 1967, disponível no Acervo de Escritores Mineiros (UFMG); Antonio Candido, "A nova narrativa" (1979), in A educação pela noite, Rio de Janeiro: Ouro sobre Azul, 2006, p. 249.

12 Cf., por exemplo: Jorge Schwartz, Murilo Rubião: a poética do uroboro, São Paulo: Ática, 1981; Davi Arrigucci Jr., "O sequestro da surpresa", in Outros achados e perdidos, São Paulo: Companhia das Letras, 1999; Rui Mourão, "O pirotécnico Zacarias", in Revista Colóquio, Lisboa, v. 25, p. 96-7, maio 1975; Benedito Nunes, "O convidado", in Revista Colóquio, Lisboa, v. 28, p. 91, novembro 1975; Fábio Lucas, "A arte do conto de Murilo Rubião", in Mineiranças, Belo Horizonte: Oficina de Livros, 1991; José Paulo Paes, "Um sequestro do divino", in A aventura literária: ensaios sobre ficção e ficções, São Paulo: Companhia das Letras, 1990.
} 
família muito grande de ficcionistas contemporâneos". ${ }^{13}$ Diz-se, deslocando ênfase e enfoque: “fantástico", esta matriz plural, entendida facilmente de forma ampla, às vezes sem escrúpulos de fronteira, que esparrama sua transgressão, que se espalha, diferentemente, do maravilhoso ao estranho, do mítico ao religione, do gótico ao horror sobrenatural, do metafísico ao esotérico, do parodístico ao absurdo-existencial, do alegórico ao poético - substituindo, assim, metalinguisticamente, uma palavra por outra. "Fantástico" é a ideia às vezes utilizada como designação mais ou menos aleatória para dar conta de alguns objetos cujo poder de fantasia ou distorção parece cambiar em insuficientes as ordens previstas por uma "realidade visível". Como ideia antiguíssima, aberta desde os gregos, parece ter sido posta primeiramente no Sofista, a partir de uma distinção entre proporção e desproporção, quando o Estrangeiro eleata analisa a mimese separando duas espécies de imagens: imagem icástica, proporcional ao paradigma, e imagem fantástica, deformação ou desproporção da imagem icástica: a desproporção dependendo, pois, de uma supraconvenção (referência) que a proporcione como desproporção. ${ }^{14}$ Separada ou não das interpretações modernas construídas a partir do legado crítico europeu e americano, inserida quase sempre em tentativas de especificar as fases de uma tradição literária, a ideia depende do contexto, da sua circunscrição em um campo semântico, da sua elasticidade aqui e ali, antes, agora e depois, de pontos referenciais, de estar, por assim dizer, em repouso ou movimento, como títere manejado por múltiplas mãos (por exemplo, em termos de abrangência, fantástico stricto sensu ou lato sensu). ${ }^{15}$ Nela, oscila-se entre séries variáveis de nomenclatura, dado que uma determinada classificação corresponde a determinado modo de entrelaçar hipóteses e constituir premissas: diferenciadamente, fantástico e maravilhoso; simetricamente, fantástico tradicional, fantástico contemporâneo (neofantástico, realismo fantástico, realismo mágico, realismo maravilhoso). ${ }^{16}$ Também: especialmente para a produção contemporânea, crescem em número e grau, por subdivisões e combinações, arranjos de códigos e epítetos, ao lado das categorias mais conhecidas - movendo-se, assim, escolasticamente, como superespecificação: realismo mágico metafísico, antropológico ou ontológico; realismo psíquico, mítico ou grotesco etc. ${ }^{17}$

\footnotetext{
13 Fábio Lucas, “A arte do conto de Murilo Rubião”, in Mineiranças, Belo Horizonte: Oficina de Livros, 1991, p. 212.

${ }^{14}$ Cf. Platão, Sofista, São Paulo: Abril Cultural, 1983, p. 153-4.

15 Sínteses das discussões podem ser encontradas em: Remo Ceserani, O fantástico, Curitiba: Ed UFPR, 2006; Selma Calasans Rodrigues, O fantástico, São Paulo: Ática, 1988.

16 Sobre o fantástico contemporâneo, cf., especialmente: David Roas, "La amenaza de lo fantástico" e Jaime Alazraki, "Qué es lo neofantástico?", in David Roas (org.), Teorías de lo fantástico, Madrid: Arco Libros, 2001.

${ }^{17}$ Cf., por exemplo, William Spindler, "Magic realism: a typology", in Fórum for modern language studies, Oxford, n. 39, 1993, p. 75-85; Jeanne Delbaere-Garant, "Psychic realism, mythic realism, grotesque realism:
} 
As denominações não são ingênuas ou inocentes: pressupõem os significados historicamente dados. Cortázar, que refletiu muitas vezes sobre o tema, foi um dos que reconheceram o problema da nomenclatura: "Quase todos os contos que escrevi pertencem ao gênero chamado fantástico por falta de nome melhor". ${ }^{18}$

Do ponto de vista da criação, as pirotecnias narradas resultam, sob controle, de uma deliberação produtiva (no caso, escritas e reescritas pelo autor muitas vezes). Não têm origem naquele processo desencadeador instantâneo, sem aviso prévio, quase sem esforço, ao qual Cortázar, por exemplo, refere-se ao falar de sua condição de contista e dar o seu testemunho de criação. ${ }^{19}$ Em Rubião, ao contrário, existe algo de muito fabricado, burilado: vulnerável a séries sucessivas de reescritura, modificável por natureza, mas resultando de planos preconcebidos que visam obter algum efeito geral: "para dar ao leitor a certeza de que elas prosseguirão indefinidamente, numa indestrutível repetição cíclica”. Rubião foi obcecado pela reescrita, desfazendo a expectativa de cristalização do produto artístico. Os contos nunca se tornaram definitivos: perecíveis os títulos, os finais das histórias, os nomes das personagens, as soluções sintáticas. As narrativas foram se transformando no decorrer dos anos, o volume da obra pouco foi ampliado. ${ }^{20} \mathrm{~A}$ cada nova edição, submeteu os textos já publicados a revisões em que reduziu ou eliminou parágrafos, sintetizou ideias, alterou expressões, permutou lexemas - sempre à procura de uma nova forma. ${ }^{21}$ Transportou histórias efêmeras à luta corporal com a palavra, o que devia ser, em escritores como ele, vício e maldição. Escrever era reescrever, processo incessante. Preservava-se o eixo principal ou o tema de um conto e a escrita ia recebendo ajustes. O trabalho do artesão obcecado, como um ourives minucioso, muitas vezes subtraía informações vitais, gerando no leitor da versão mais recente a impressão de que algo do encadeamento tinha sido mal realizado, adverso à linearidade. ${ }^{22}$

variations on magic realism in contemporary literature in English", in Lois Parkinson Zamora e Wendy B. Faris, Magical realism: theory, history, community, Durham e London: Duke University Press, 1995.

18 Julio Cortázar, Valise de Cronópio, São Paulo: Perspectiva, 2008, p. 148 (grifo nosso).

${ }^{19}$ Cf. Julio Cortázar, ibidem., p. 232-234.

${ }^{20}$ Dos livros publicados - O ex-mágico (1947), A estrela vermelha (1953), Os dragões e outros contos (1965), O convidado (1974), O pirotécnico Zacarias (também 1974), A casa do girassol vermelho (1978) e O homem do boné cinzento e outras histórias (1990) - seguem algumas traduções dos contos: para o inglês, The Ex-Magician and Other Stories (1979), de Thomas Colchie; para o alemão, Der Feuerwerker Zacharias (1981), de Ray-Gude Mertin; para o checo, Dum u Cervené Slunecnice (1986), de Pavla Ludmilová; para o espanhol, La casa del girasol rojo y otros relatos (1991), de Cyro Laviero.

${ }^{21}$ Considerando que os contos foram reescritos ao longo dos anos, este trabalho toma Obra Completa (2010) volume contendo a última versão das trinta e três narrativas do autor - como única referência de análise: Murilo Rubião, Obra Completa, São Paulo: Companhia das Letras, 2010.

${ }^{22}$ Cf. o estudo de Maria do Rosário Valencise Gregolin, "A reescritura como gênese da poética de Murilo Rubião", in Revista Estudos Linguísticos e Literários, Salvador, UFBA, v. 20, p. 55-63, 1997. Como exemplo, cf. as alterações do conto "O ex-mágico da Taberna Minhota" numa tabela organizada por Jorge Schwartz: Murilo Rubião: a poética do uruboro, São Paulo: Ática, 1981, p. 89-92. 
Numa carta a Mário de Andrade, escrita quatro anos antes da publicação de $O$ ex-mágico (1947), o primeiro livro, Rubião já dissertava sobre a dificuldade de escrever e a obsessão da reescrita: “Ainda não consegui, após cinco anos de uma luta feroz com a literatura de ficção, realizar um conto definitivo". ${ }^{23}$ Tal luta insana com o texto fizera com que Mário, em 1944, escrevesse ao amigo, em tom de gracejo: "Eu imagino que onde você se devasta perigosamente é na esperança abusiva de encontrar a expressão perfeita e única do que você quer dizer. O Diabo tanto consertou o olho do filho que furou". ${ }^{24}$ Mário questionava esta esperança de aprimoramento pela reescrita sublinhando a independência do efeito artístico: “Está claro, Murilo, que você deve se preocupar muito com a 'sua' expressão da 'sua' obrade-arte, mas desque você se lembre que esta obra vai ter vida própria, independente de você, essa preocupação se torna esportiva e mesmo lotérica [...] O seu exaspero da expressão é positivamente um suicídio. É mau isso., 25

Na entrevista a Granville Ponce, Rubião também define o seu método de reformulação: "Reelaboro a minha linguagem até a exaustão, numa busca desesperada da clareza. Se usasse palavras impregnadas de símbolos ou concebidas em laboratório, a leitura dos meus textos seria dificílima". ${ }^{26}$ Porventura não houvesse omissões cômodas e miúdas na personalíssima resposta, a ideia seria precária: pressuporia que os paradoxos da linguagem literária podem ser resolvidos meramente por meio de estilo econômico, fuga do rebuscamento, depuração; ignoraria depois que o apagamento ou a substituição de partes elimina, às vezes, exatamente o que dava uniformidade às intrigas; desconsideraria enfim que a condensação das ideias quase sempre torna o efeito do texto mais opaco, independentemente de palavras impregnadas ou não "de símbolos". Escolha-se uma narrativa ao acaso, para verificar que o procedimento de reescrita produziu apenas brechas escuras e não melhorias. Compare-se a primeira versão de algum conto (por exemplo, conforme enviada a Mário no início dos anos quarenta ${ }^{27}$ ) com a sua versão final: apenas mudanças arbitrárias, não exatamente necessárias. Não se sabe como observadores poderiam compreender, sem o crivo do processo redundante, os laços frouxos de seu texto. Rubião fez alterações que chegaram a três ou quatro reedições, síncopes da circularidade de um processo criativo que ocorre também na camada dos temas: os fetiches

\footnotetext{
${ }^{23}$ Marcos Antonio de Moraes (org.), Mário e o pirotécnico aprendiz (cartas de Mário de Andrade e Murilo Rubião), Belo Horizonte: Editora UFMG, São Paulo: IEB/USP, São Paulo: Editora Giordano, 1995, p. 39.

${ }^{24}$ Marcos Antonio de Moraes (org.), ibidem, p. 76.

${ }^{25}$ Marcos Antonio de Moraes (org.), ibidem, p. 76-7.

${ }^{26}$ Cf. J. A. de Granville Ponce, "Entrevista - O fantástico Murilo Rubião", in Murilo Rubião, O pirotécnico Zacarias, São Paulo: Ática, 1998, p. 4.

${ }^{27}$ A transcrição das primeiras versões de alguns desses contos pode ser encontrada também em Marcos Antonio de Moraes (org.), op. cit., p. 104-184.
} 
acumulativos em "Bárbara", as ninhadas de filhos em "Aglaia", a escandalosa repetição e sobreposição dos meios em "A fila", o movimento circular em "Petúnia" etc. Na prática, o importante talvez não fosse a obra acabada, mas o ato de re-criar, o corpo-a-corpo com a palavra. Como as personagens de seus contos, enclausuradas num mundo sufocante, transformando-se muitas vezes aleatoriamente ou buscando uma saída que nunca é encontrada, Rubião vivia o processo como uma maldição: a reescrita evocava a ideia de obra que não se cristaliza, que pode ser retomada ad infinitum, como referida pelo escritor na mesma entrevista: "Sempre aceitei a literatura como uma maldição [...] Somente quando estou criando uma história sinto prazer. Depois é essa tremenda luta com a palavra, é revirar o texto, elaborar e reelaborar, ir para frente, voltar. Rasgar". ${ }^{28}$

As justificativas são protocolares, é claro; dispensam a complexidade do problema. Pense-se uma reescrita como methodos, palavra grega que pode significar "caminho para chegar a um fim", como "busca" (tal como se diz "busca da clareza"), ainda que o fim não seja fixado de antemão, de modo deliberado ou refletido: se há um método numa reescrita, realiza-se sob a face dupla da circunspecção e da abertura inevitável para o não deliberado, o não premeditado. Toda pretensão de reescrita pressupõe e tenta enfrentar um universo de imprevisibilidade - dos efeitos da linguagem, da leitura e da sensação, por exemplo - cuja dinâmica, com propiciações, limites e impasses, não cessa de flagrar, na escrita, funções de contenção apenas relativas e de organização sempre precárias. Em qualquer "busca desesperada da clareza", não se leva em conta, por exemplo, que tal clareza nunca pode ser atingida pelo texto literário: aberto, polissêmico, ambivalente, na ambiguidade inerente à linguagem, nas múltiplas possibilidades de interpretação, dependente que é do leitor, renascendo diverso a cada leitura: "a literatura é a linguagem que se faz ambiguidade", diz Blanchot. ${ }^{29} \mathrm{O}$ ato da leitura é uma tentativa de desembrulhar a intentio operis, desembrulho realizado de maneiras variáveis, o que pressupõe igualmente contínuas "atualizações"; tentativa que pode desorganizar de modo imprevisível e inevitável muitos dos elos dispostos pela intentio auctoris - no que, então, o texto também já terá sido "reescrito" pela intentio lectoris. O outro lado do problema é que muitas vezes a "clareza" não é de forma alguma clara: dificulta absolutamente as tentativas de desembrulho, como uma pirotecnia, densa, maciça, imóvel, podendo ser decidida como não-senso. Daí que seja melhor dizer: o que o leitor crítico não entende ou não consegue discriminar tem origem exatamente num modo ativo de produzir uma narrativa que causa um leitor com dificuldade de entender e

\footnotetext{
${ }^{28}$ Cf. J. A. de Granville Ponce, op. cit., p. 5.

${ }^{29}$ Maurice Blanchot, "A literatura e o direito à morte", in A parte do fogo, Rio de Janeiro: Rocco, 2011, p. 348.
} 
discriminar: esta invenção pronta a decidir-se em não-significado, esta potência para nascer e morrer no figural. De qualquer forma, não obstante o desuso de palavras concebidas em laboratório ou linguagem pretensiosa, um conto caudaloso como "A lua", por exemplo, cuja brevidade lembra muito o "Continuidad de los parques" de Cortázar, dificilmente será "claro". Nem luz, nem luar - a primeira frase do narrador. O sorriso de massa - a última, duas páginas depois.

Recuperar aqui o seu processo de recriação é, sobretudo, recompor a sua atitude crítica sobre o devir do texto, a responsabilidade por projetá-lo, dotá-lo e desdobrá-lo, contraditoriamente, com uma vulnerabilidade ou com uma atomicidade pouco afeita ao determinismo substancialista que caracteriza certos tipos de leitura: o escritor como um animal à espreita, orelhas levantadas, muito atento ao seu território. Há aí, de uma escrita a outra, não um desenvolvimento, mas uma mutação circular, na necessidade de avaliar e reavaliar cada produção no seu registro; não o adiamento da satisfação, mas a impossibilidade da satisfação: o instante perene da escrita, do traço, da tinta mal seca, o gesto extremo do escritor reduzido ao gesto do artesão que quer chegar a uma última forma sabendo que esta última forma será apenas a última de um momento definido, podendo se tornar aí penúltima, antepenúltima (como ocorre, semelhantemente, nas redes de significado). O objetivo marcado por uma inquietação mítica de "clareza", mexe e remexe que apenas tornam menos claras as histórias, frustra-se sempre, repetidamente: a atenção ao território o leva ao território da morte. É ele, em si, um objetivo intransitivo tantos forem os intransitivismos que produz: inútil objetivo, estúpido objeto. O melhor exemplo está no já citado "Marina, a Intangível”, espécie de metaconto emblemático quando se tenta conectar ficção e confissão. ${ }^{30}$ Em cena, o problema da atividade criadora: a relação conflituosa do jornalista Ambrósio consigo mesmo, que se desdobra da inibição ao desespero, na espera por alguma coisa que precisa acontecer. As horas são marcadas pelas pancadas de um relógio inexistente. Uma cesta repleta de papéis amarrotados o desencoraja. Move-se, desinquieto, na cadeira. Estéril, olha com impotência as brancas folhas de papel: rabiscara umas poucas linhas desconexas. Põe-se a escrever uma história, mesmo a mais caótica e absurda. Quando as frases vêm fáceis e enchem numerosas laudas, descobre que faltara o assunto, escrevera a esmo. A dificuldade, é claro, aporta à impossibilidade de se tocar algo intangível - a tarefa da escrita vista como "maldição", texto

\footnotetext{
${ }^{30}$ Para Batalha, este conto tanto ilustra a concepção de literatura de Rubião quanto revela as fontes nas quais o escritor foi buscar sua poética: Cf. Maria Cristina Batalha, "Murilo Rubião e as armadilhas do verbo: a euforia e o desencanto", in Revista Letras \& Letras, Uberlândia, v. 19, p. 99-113, 2003. Cf. também Albert von Brunn, "Murilo Rubião: uma poética do emudecimento", in Wander Melo Miranda (org), A trama do arquivo, Belo Horizonte: UFMG, CEL/UFMG, 1995.
} 
que não se concretiza. Abre então a Bíblia e descobre o assunto procurado: Iria falar do mistério de Marina, a Intangível, também conhecida por Maria da Conceição. Aparece na janela o poeta desconhecido de nariz grosso e curvo: ele traz versos para Marina. Por meio de gestos vagarosos feitos com as mãos, ele ensina a Ambrósio lindos e invisíveis versos. Falta compôlos, no entanto. Dá-se então a miscelânea esquisita no quintal-jardim-terreiro. Como num ritual mágico, pétalas jogadas ao chão formam palavras indecifráveis. Acontece o estranho cortejo de seres. Marina, a conceição, a que concebe, chega num andor, depois vai embora. Apesar deste processo longo, belicoso e cansativo, no final o que fica? Apenas um poema, dir-se-ia, "sem nexo": Feito de pétalas rasgadas e de sons estúpidos.

Os versos para Marina não têm forma ordinária: conforme ensina o desconhecido, os primeiros cantos são feitos de rosas despetaladas, lembram o paraíso antes do pecado; os últimos inexistem. Marina tem carga erótica: mulher com os lábios excessivamente pintados, vestida de cetim amarfanhado e rasgado, por onde Ambrósio entrevê coxas brancas, benfeitas. Ao mesmo tempo, ela vem num andor forrado de papel de seda, como uma santa, e traz na mão direita o girassol a ser também desfolhado nos versos. É narrativa muito avessa àquele balizamento requerido por certos módulos prosaicos nos quais ainda se diz assim, não sem motivo de paródia: se um conto é sobre um jornalista em plantão noturno, jamais uma Filarmônica Flor-de-Lis ou padres sardentos e mulheres grávidas podem invadir o espaço. Não é a que o senso comum gosta ou a que os cânones literários aceitam. Até Cortázar reclamaria desta impermeabilidade final, deste full-time do fantástico, tendo se queixado da "má literatura fantástica" em que os perfis insólitos ora são "introduzidos como cunhas instantâneas e efêmeras na sólida massa do habitual", ora aparecem "invadindo a quase totalidade do cenário com grande espalhafato de espetáculo sobrenatural". ${ }^{31} \mathrm{Com}$ a maior naturalidade, ela incorpora o excesso, fragmenta o visual, desbarata a ideia de significado, num efeito de invenção, entendido aqui em sua máxima liberdade, que presta respeito litúrgico à forma final jogada ao vento. Nega o âmbito discursivo pela radicalidade com que se torna cortada de eventos e imagens singulares - e fica numa espécie de entreato: engenho que engole mensagens, violenta silogismos e aquele purismo apologético da customização dos elementos, purismo dos espaços amplos e vazios. O ornamento é, nela, um gozo, não um crime: arquitetura carregada, ecletismo, apliques.

Vieram os padres capuchinhos. Galgaram, ágeis, o muro, soprando silenciosas trombetas. (Dez muros tinham saltado e ainda teriam que saltar dez.) Um pouco atrás, vinha a Filarmônica Flor-de-Lis, com os pistonistas envergando

\footnotetext{
${ }^{31}$ Julio Cortázar, Valise de Cronópio, São Paulo: Perspectiva, 2008, p. 236.
} 
fardas vermelhas. Tocavam os seus instrumentos separadamente e sem música. Simplesmente soprados. Encheram a noite de sons agudos, desconexos, selvagens.

O coral dos homens de caras murchas veio em seguida. Seus componentes escancaravam a boca como se desejassem cantar e nenhum som emitiam. Um deles, vestido de sacristão, carregava o relógio da capela dos capuchinhos.

Nem cheguei a me alegrar, constando-lhe a existência, porque, num andor forrado de papel de seda, surgiu Marina, a Intangível, escoltada por padres sardentos e mulheres grávidas. Trazia no corpo um vestido de cetim amarfanhado, as barras sujas de lama. Na cabeça, um chapéu de feltro, bastante usado, com um adorno de pena de galinha. Os lábios, excessivamente pintados, e olheiras artificiais muito negras, feitas a carvão. Empunhava na mão direita um girassol e me olhava com ternura. Por entre o vestido rasgado, entrevi suas coxas brancas, benfeitas. Hesitei um instante, entre os olhos e as pernas. Mas anjos de metal me prejudicaram a visão, enquanto as figuras começaram a crescer e a diminuir com rapidez. Passavam velozes, pulando os muros, que se estendiam continuamente, ao mesmo tempo que os planos subiam e baixavam.

Eu corria de um lado para outro, afobado, arquejante, ora buscando os olhos, ora procurando as coxas de Marina, até que os gráficos encerraram a procissão. Os linotipos vinham voando junto aos obreiros, que compunham, muito atentos ao serviço. Letras manuscritas e garrafais. Os impressores, caminhando com o auxílio de compridas pernas de pau, encheram de papel o quintal.

O cortejo passou em segundos, e os muros, que antes via na minha frente, transformaram-se num só. Quis correr, para alcançar o andor que levava Marina, porém os papéis, jogados para o ar e espalhados pelo chão, atrapalharam-me.

Quando deles me desvencilhei, encontrava-me só no terreiro e nenhum som, nenhum ruído se fazia ouvir. Sabia, contudo, que o poema de Marina estava composto, irremediavelmente composto. Feito de pétalas rasgadas e de sons estúpidos.

Como numa volta ao ornatus (tido por alguns modernos como kitsch, filistinismo), ângulos agudos são enfatizados: bagunça transcendente, proliferação de detalhes, signos razoavelmente pesados, pastiche. Ambrósio é tomado por uma apocalíptica mais densa do que o tema exigiria: mil orquestras ao mesmo tempo, galeria difusa, pirotecnia, caos-cosmos. O conto serpeia uma metafísica do intangível que se torna uma terrinha lamacenta - ou, para dizer como Foucault, ao falar das heterotopias em um conto de Borges: "as coisas aí são 'deitadas`, 'colocadas`, 'dispostas` em lugares a tal ponto diferentes, que é impossível encontrar-lhes um espaço de acolhimento, definir por baixo de umas e outras um lugarcomum". ${ }^{32} \mathrm{O}$ leitor desprevenido não se convence sobre a necessidade de uma topografia tão complicada; pergunta, negativa ou positivamente: qual o significado desta falta de significado? Conjectura que tal tumulto decorativo representa no fundo uma crescente superficialidade, um olhar maravilhado e ingênuo que salva para si um pedaço da infância. Sente-se, talvez, como Valéry ao visitar o Museu do Louvre. ${ }^{33}$ A comitiva de anjos de metal, gráficos e obreiros estaria reinando então num tempo e num espaço caóticos que serviriam

\footnotetext{
${ }^{32}$ Michel Foucault, As palavras e as coisas, São Paulo: Martins Fontes, 2007, p. XII-XIII.

${ }^{33}$ Cf. Paul Valéry, "Le problème des musées", in Jean Hytier (ed), Paul Valéry - Oeuvres II, Paris: Gallimard, 1960, p. 1290-93. Cf. também Theodor Adorno, "Museu Valéry Proust", in Prismas - crítica cultural e sociedade, São Paulo: Ática, 1998, p. 173-85.
} 
somente para apagar a distância sólida entre fantasia e realidade (como nem um Kafka teria tido o mau gosto de fazer). Entretanto, mesmo sob esta primeira impressão de gratuidade debalde e sob o que haveria de "fantasia fácil" nesta galeria anárquica, o relato enfim consegue convencer exatamente por impor um cenário rico enquanto profusão de signos descontextualizados, certo jogo vazio de espelho entre eles, um desconcerto, uma desorientação, ao mesmo tempo em que dialoga diretamente com a imprevisibilidade de um querer-escrever que se abre ao não deliberado, ao não premeditado, ao inconcluso. $\mathrm{O}$ excesso leva a uma espécie de "tudo pode": a narração se torna obsessiva, o sistema entra em pane pelo desalinhado exagero de seus elementos. Meio lá, meio cá, o que poderia torná-lo apenas previsível enquanto tensão de intriga descamba nesta implosão. Sua força está na palpitação e na ressonância: arranca o leitor da realidade desbotada para colocá-lo num mosaico indiscernível; sobretudo, talvez, para colocá-lo no que não "existe", no que insiste ou subsiste (como operação lógica, como formulação de pensamento impensável) tal como se é: uma dilatação do silêncio, do intervalo, do não-dizer por tanto dizer - feito pétalas rasgadas, sons estúpidos. 


\section{III - SENSO E NÃO-SENSO}

É preciso pensar em termos incertos, relativos, idolatrar a dúvida - talvez, uma arte de desaprender. Interessa em algum Rubião que na página a história tenha várias entradas e saídas, oscile, fuja por todos os lados, sem verdade oculta, mas também que tenha becos, ruas sem saída, aporia. A intimidade do coloquial e a bobeirinha opaca e poderosíssima de fantasias quase carrollianas (embora em Carroll pareça haver ritos de passagem: cair na toca, atravessar o espelho ${ }^{34}$ ), o desvario paradoxal que se disfarça numa ressonância harmoniosa, o cômico do sobre-humano como um risinho desenhado pelo canto da boca, o engenho quase kafkiano na superfície que se estende - estas coisas, nele, são uma língua estrangeira na própria língua, como se pode lembrar Proust em Contre Sainte-Beuve: "Os belos livros são escritos numa espécie de língua estrangeira. Sob cada palavra cada um de nós coloca seu sentido ou pelo menos sua imagem, que é sempre um contrassenso. Mas nos belos livros, todos os contrassensos que ocorram são belos". 35 O senso comum estabelece que em todas as coisas há algum significado ou que em todas as coisas se preserva uma pluralidade de significados; o contrassenso, que também é belo o disparate simultâneo das indicações desconexas - por vezes, o nulo, a posição zerada. Eis aí por que aquela prosa chamada "representacional", da tipificação sob o suposto índice da abrangência e da totalidade (que não pressupõe a erosão do próprio "princípio de realidade" ao pressupor um "real" como bem formado, normal, habitual, familiar, verdadeiro), geralmente não encontra resistência entre os leitores: comparam as experiências narradas com as suas, projetam-se muitas vezes nelas, deformam-nas pela atribuição de sentimentos e ideias - aquela prosa, mesmo com algumas excentricidades, pensa-se, serve para alguma coisa, pode ser tolerada. Mas esta prosa bocadinha de Rubião não lhes oferece prêmio instantâneo, informação polida, utilidade, compensação: é efetivamente uma língua atravessada por outra, não reflexiva, não comunicativa, sempre aquém ou além. Seu expediente de fantasia é, em espécie, intransitivo: histórias com escopos triviais (ou até mesmo piegas), betumadas por quinquilharias fantásticas, despencam, intencionalmente, num remate obscuro, indefinido, mas suficiente em si mesmo. Indaga-se, depois, sobre a sua significação (quando o bom senso exige do leitor algumas fixações de significado, uma coerência de conjunto); mas aí se vê que são resistentes:

\footnotetext{
${ }^{34}$ Para uma síntese das reflexões sobre Carroll, cf. a introdução de Sebastião Uchoa Leite, "O que a tartaruga disse a Lewis Carroll”, in Aventuras de Alice, São Paulo: Summus, 1980.

${ }^{35}$ Marcel Proust, Contre Sainte-Beuve, São Paulo: Iluminuras, 1988, p. 141.
} 
constituem um ilimitado que facilmente contesta a definição, paradoxo das coisas, na Coisa; às vezes, uma pirotecnia que se permite irredutível.

Evidentemente, nunca se afirma com isso que tal língua estrangeira, ou tal posição zerada, ou tal irredutibilidade, alcança a mesma intensidade, a mesma potência ou o mesmo valor em todas as narrativas. Embora alguma estrangeirice esteja sempre presente em Rubião, existem momentos em que ela se realiza melhor. Neste capítulo, pensa-se o caso somente em torno de alguns contos - especificamente, "A casa do girassol vermelho", "O pirotécnico Zacarias" e "A flor de vidro". Neles, parece haver com maior nitidez uma espécie de "estética quântica": na ciranda dos dispositivos significativos, algo, em algum momento, pirotecniza as possibilidades de significação, viabilizando-se como uma não-significação. Potencializada como imagem pura, esta não-significação pode ser pensada nessas narrativas como o intransitivo, o indizível, o figural. Há, por exemplo, uma imagem qualquer que não se massifica na geleia fictícia, mesmo quando recorrente: ali, ela toma força na medida em que é parte dissonante, quando o todo finge ser assonante (talvez, não se possa dizer o mesmo quando o todo se parece dissonante, como nas hipérboles acumulativas em "Bárbara" ou em "Aglaia": um exagero de acrobacias só se dá à impureza de uma imagem-movimento acrobática, ao passo que uma pirueta única se dá à pureza de uma imagem-tempo irredutível; generalizações de modos desfavorecem especializações de modos, da mesma maneira que uma corda toda retorcida desfavorece a beleza de um nó solitário): as "pétalas", o "branco", a "flor". A construção deste algo indizível em textos literários sempre força uma experiência sobre senso e não-senso, essas entidades proverbiais especialmente complexas, arrojadas, mas às vezes detidas num parti pris - ora delimitadas como instâncias facilmente categorizáveis, ora dinamizadas somente em distinção e polaridade (não raramente, da mesma forma que se pensa uma contradição falso e verdadeiro, pensa-se uma contradição senso e não-senso, não uma relação paradoxal). O princípio de contradição pode até absolver algumas imagens, mas não outras, como escreve Octavio Paz em sua contribuição crítica sobre as imagens poéticas. ${ }^{36}$ É claro: o problema do senso e do não-senso em Rubião não pode ser pensado à revelia dos problemas conceituais (assim se faz, às vezes, simplesmente: como se não houvesse inúmeros problemas conceituais quando se pensa literatura, ou como se a literatura fosse subserviente ao pragmatismo positivista da departamentalização disciplinar): investir sobre os textos rubianos, neles, com eles, por eles, exige imediatamente investir sobre as premissas que organizam o investimento fundamental, deles (nos horizontes de pensamento potencializados

\footnotetext{
${ }^{36}$ Cf. Octavio Paz, “A imagem”, in Signos em rotação, São Paulo: Perspectiva, 2009.
} 
por eles). Por isso, far-se-á aqui um movimento oblíquo: senso e não-senso como âmbito de texto, mas também como âmbito nocional, pelo terreno dos conceitos - sim, numa determinada perspectiva de abordagem. Depois, uma experiência microscópica em "A flor de vidro" encerrará o capítulo.

Como introdução, é útil e prático ilustrar o problema a partir de uma polaridade senso e não-senso. Tal polaridade pode ser sugerida de forma semelhante a que Bachelard, ao pensar uma poética do espaço, sugere a polaridade do sótão (zona racional dos projetos intelectualizados) e do porão (instância em que o devaneio trabalha): "No sótão, camundongos e ratos podem fazer o seu alvoroço. Quando o dono da casa chegar, eles voltarão ao silêncio da toca. No porão agitam-se seres mais lentos, menos saltitantes, mais misteriosos [...] No sótão, a experiência diurna pode sempre dissipar os medos da noite. No porão há trevas dia e noite". ${ }^{37}$ Pense-se então, analogicamente: no âmbito do senso, movimentam-se dimensões que podem provocar alguma inquietação - mas isto somente até certo ponto: ali se instala em algum momento a exuberante luz elétrica do leitor (trânsito nos possíveis significados), haverá sempre a possibilidade de alguma iluminação que o civiliza como senso. No não-senso, ao contrário, a única luz possível é a vela (frágil, insuficiente), que faz o leitor pensar o impensável, exagerar exageros, ver nas paredes de subsolo, escuras e úmidas, inúmeras imagens imaginadas, confusas, à luz da vela, dissolvidas na penumbra. Num conto como "A casa do girassol vermelho", em que a erotização das personagens, na relação de permuta entre casais - primeiramente, Surubi e Marialice, Nanico e Belinha; depois, trocados, Surubi e Belinha, Nanico e Marialice (desde o início o leitor precisa tomar lápis e papel para anotar quem fica com quem) -, compõe-se como catarse dos "dias de desespero do passado", transita-se, com a profusão de uma lâmpada, nas sugestões do senso das relações, na medida em que tais relações se revelam demasiadamente fecundas e vinculadas, umas vezes em si mesmas, outras vezes na potência do embate com o velho Simeão, o pai de adoção (embate que não encontrara termo nem mesmo depois da morte do velho, sendo continuamente retomado, simbolicamente, por modos purgativos: violações exacerbadas do comportamento anteriormente exigido, xingamentos ou insultos, imprecações, Simeão escarrado): os prazeres eróticos e violentos entre as personagens se realizam por meio de vínculos essencialmente físicos, em que socos, diabruras e ameaças convivem com mãos que tocam seios, corpos nus e molhados que se abraçam e bocas que se colam, até o festim final na "represa", quando Xixiu, irmão de Belinha, efetivamente some, ao mergulhar e

\footnotetext{
${ }^{37}$ Gaston Bachelard, A poética do espaço, São Paulo: Martins Fontes, 2008, p. 37.
} 
desaparecer numa curva do "açude"; depois disso, todos são tomados por uma apatia generalizada, na qual fica evidente que o "alucinado", "frenético" e "convulso" Xixiu assumia uma posição relevante para as transgressões de modos idealizadas por eles: Sabíamos que nada mais seria importante, digno da violência, da paixão. Um futuro mesquinho nos aguardava: Belsie se amarraria a um agressivo mutismo. Marialice e Nanico - dois idiotas - olhariam um para o outro indefinidamente, alheios a qualquer determinação de romper com o mundo. Todavia, o que pode se tornar patente no âmbito do senso se vampiriza com o não-senso, especialmente qualificado na situação final, no último parágrafo, no intraduzível e excêntrico surgimento de pétalas no ventre de Belinha (Esticou para o alto os olhos inexpressivos e embaçados. Abaixou-os depois para o ventre, onde começavam a surgir as primeiras pétalas de um minúsculo girassol vermelho) - aí o leitor só pode usar a penúria da vela (como num porão à meia-luz, fantasiar, imaginar, "pensar ter visto" movimentos de seres e coisas nas sombras da parede rugosa - já não simplesmente interpretar que "isto implica aquilo"). Ele pôde ler, linhas antes, uma referência avulsa, muitíssimo vaga e indireta, de que Belinha, irmã de Xixiu, estava "grávida", aparentemente: Belinha, sem os apelos do irmão, não sentiria explodir a carne e guardaria para si o fruto da fecundação. Mas grávida de quê? Pétalas: um filho, um cancro, uma fome, uma tripa, um nada? Beco indelével. Cena muda, mudamente. Pode-se dizer que o senso foi abortado: a pirotecnia das pétalas que surgem no ventre produz mil rabos e cabeças, um monstro que se espessa, misterioso e desértico em sua irredutibilidade, semanticamente retraído e denso, como um cafundó aquém ou além de significações: o recuo para aquém do evidente ou o avanço para além do evidente pode ser lido agora apenas como "algo" ou como Coisa (e não uma "coisa" exterior - afirmar-se-ia, assim, saussurianamente: não se pode confundir um significante, a imagem acústica, com a "palavra" pétalas numa página; não se pode confundir um significado, o conceito, com a “coisa" efetiva que constitui a corola das flores). No ponto da expressão, desde que o leitor o provoque, toda uma celeuma desperta: há o que se põe no tempo (primeiras) e o que se põe no espaço (minúsculo), mas também há o indizível da Coisa a designar, quando são impotentes os vocábulos - esta, a propriedade fundamental da linguagem, limite e recurso, o existir mais coisas na Coisa do que vocábulos -, pelo que sobre ela talvez nada deva ser dito senão focalmente: pétalas que são pétalas (em que não é viável perguntar o seu significado na história: podem ser decididas como não-significado), forma solitária e não solidária, que nada de fora contém ou diz, que apenas se contém e se diz. Enquanto as "pétalas escarlates" que aparecem no peito de Galateu, em "O lodo", correspondem a um modo de expressar o desenho de uma ferida sangrenta (ferida em forma de pétalas: No lugar despontara uma ferida sangrenta, aberta em pétalas escarlates), as "pétalas de um minúsculo girassol vermelho" em 
Belinha podem ser, e as são melhor, exata e unicamente "pétalas". Sim, decidida como imagem pura: o não-senso próprio a esse visível, o que o torna invisível, é que só se deve falar dele a partir dele mesmo, indizível: fácil de imaginar, difícil de compreender.

Valoriza-se nisto, vê-se, o desempenho do texto e de uma primeira leitura. Contudo, pensar tal polaridade de forma tão demarcada simplifica ao extremo algo mais complexo: não é senão batizar o problema, dar-lhe um status inicial. Não se pode ver apenas o senso nem apenas o não-senso, tampouco ver o arranjo literário a partir de uma fórmula "a $o u$ b" : o que o conto uniu o leitor não separa. Em Rubião, os dois âmbitos fervilham na mesma saliva: senso e não-senso têm um lugar-comum - convém pensar se há uma relação entre eles, como um "a $e$ b". Não se trata exatamente do arbitrário em encontros insólitos, como se comporia o belo enlace de uma máquina de costura e um guarda-chuva. Entre o sótão e o porão, há um térreo (pense-se fisicamente, como na concepção mítica do universo em o Novo Testamento: no meio se encontra a terra, sobre ela o céu, abaixo dela o mundo inferior), onde o leitor, que nunca tem o poder de discernir perfeitamente as coisas, lê e des-lê. Se a percepção de um referente "casa" está investida de uma verticalidade assegurada pela polaridade porão e sótão, também está investida de uma horizontalidade assegurada pelo térreo, onde a polaridade se desfaz. Senso e não-senso se dão como realidades convergentes e paradoxais: as divindades do senso descem uma escada da mesma forma que os demônios do não-senso sobem outra escada - nos contos, ora antes, ora ao mesmo tempo, ora somente depois. Mesmo em "A casa do girassol vermelho", em que a penumbra do porão se evidencia melhor na situação final, momento em que a história se desvincula dos designados para superestimar a imagem pura das pétalas no ventre, convivem ao longo do texto sínteses sutis de uma disjunção inclusiva (e não exclusiva), que não se declina como antítese: por exemplo, o exagero do etéreo no módico (Da janela mesmo gritou para o universo, que se compunha de quatro pessoas, além dele e de minha irmã Belsie. [...] a Casa do Girassol Vermelho, com os seus imensos jardins, longe da cidade e do mundo, respirava uma alegria desvairada. [...] Estávamos alheios a tudo que não fosse nós mesmos.), no qual o nãosenso da exclamação do espaço imaginado também comporta como possibilidade o senso da efetividade do espaço vivido; ou ainda, em outro momento, a primazia do litúrgico na ação ( $E$ demos início à festa. Amarramos a mulher e, em seguida, pegamos o negro. Trouxemos a cama de Simeão para o jardim, onde estendemos o cadáver. Enfiamos uma rosa vermelha em suas mãos e cuspimos sua face), na qual o não-senso do ritualístico, com operações próximas às da Paixão, também comporta o senso da crueza firme da vingança. A percepção de horizontalidade assegurada pelo térreo insiste ou subsiste sutilmente no que, aqui, antes, foi chamado de "âmbito do senso", mas também insiste ou subsiste no momento final, no que, aqui, antes, foi chamado de "âmbito do 
não-senso", agora como síntese transfigurada, pelo movimento inexpressivo dos olhos de Belinha, entre um "alto" e um "baixo": Esticou os olhos para o alto [...] Abaixou-os depois para o ventre. O térreo senso e não-senso implica, assim, efeitos de superfície: aí, já não se pode dizer que o não-senso tem uma relação simplesmente antagônica com o senso ("senso ou nãosenso"): há algo que congrega o vazio e o cheio, o escuro e o claro, o sonoro e o silencioso, o alto e o baixo, à luz de lâmpadas e velas, produzindo uma zona intermediária que abarca ou reconcilia, paradoxalmente, senso e não-senso (diga-se, então, "senso $e$ não-senso"). Mas o engenho resulta escandaloso, pois desafia o intento de pensá-lo apenas em termos de significação: enquanto o senso, como possível âmbito de texto, é bicho manso, que se deleita e se satisfaz no máximo numa boa cumbuca com pluralidade de significados, o não-senso, também como possível âmbito de texto, é um predador, carnívoro, espalhafatoso, que devora as carnes do senso [a imagem pura final implica algo que deteriora cabalmente o percurso narrativo, pressupondo agora uma semiose não-verbal, sigética (imaginar e imaginar); a história-bestice, como efeito de superfície, em sua realidade térrea, implica, assim, algo que já não pode aspirar alturas nem profundidades, complementos solenes, tutanos].

Uma imagem pura também pode ser decidida na história de Zacarias, o vivo-morto (aqui, a simultaneidade impera: Em verdade morri, o que vem ao encontro da versão dos que creem na minha morte. Por outro lado, também não estou morto, pois faço tudo o que antes fazia e, devo dizer, com mais agrado do que anteriormente). Em sua língua, há um desenho coordenado da experiência por meio de cores (Sem cor jamais quis viver), às vezes tal qual um alargamento, nela: A princípio foi azul, depois verde, amarelo e negro. Um negro espesso, cheio de listras vermelhas, de um vermelho compacto, semelhante a densas fitas de sangue. Sangue pastoso com pigmentos amarelados, de um amarelo esverdeado, tênue, quase sem cor. Também, poetice lúcida de bêbado: A bebida, que antes da minha morte pouco me afetava, teve sobre o meu corpo defunto uma ação surpreendente. Pelos meus olhos entravam estrelas, luzes cujas cores ignorava, triângulos absurdos, cones e esferas de marfim, rosas negras, cravos em forma de lírios, lírios transformados em mãos. E a ruiva, que me fora destinada, enlaçando-me o pescoço com o corpo transmudado em longo braço metálico. No mundaréu de coisas, com formas, cores, há objetos sem pátria, impossíveis, triângulos absurdos, corpo como braço metálico, pairando como escamas na fantasia, que excedem o tamanho das cenas - semelhantes, assim, poder-se-ia dizer, a quadrados redondos, músicas caladas, almas físicas, matérias não extensas, perpetuum mobile. É claro: o vivo-morto não devaneia, o leitor devaneia. Zacarias encontra mesmo a melhor síntese de sua existência numa disposição cromática: Amanhã o dia poderá nascer claro, o sol brilhando como nunca brilhou. Nessa hora os homens compreenderão que, mesmo à margem da vida, ainda vivo, porque a minha existência se transmudou em cores. Mas há algo que, por ser recorrente, torna-se mais potente, por ser potente, torna-se mais problemático: em sua percepção, o que poderia 
ser simplesmente designado de uma forma direta e minimamente inteligível (redenção, plenitude, perfeição - estes, dir-se-ia, códigos significativos ou identificáveis, remetendo, conforme determinada episteme, a conceitos universais e gerais) é subvertido em uma espécie de não-dizer: o branco. Na indeterminação, o que é objeto de desejo e espera não suporta outro índice senão este, irredutível: Os filamentos brancos não tardariam a cobrir o céu. [...] Quando tudo começava a ficar branco veio um automóvel e me matou. [...] Simplesmente porque não seria naquela noite que o branco desceria até a terra. [...] e o branco já se aproxima da terra para exclusiva ternura dos meus olhos. Tem-se, assim, em frações, ao longo da história: não tardaria (parousia criada), quando começava a ficar (parousia interrompida), não desceria já (parousia adiada), já se aproxima (parousia recriada). Insistentemente, entre as brechas do paradoxo vivo-morto, este índice se impõe como enigma bruto, que, especialmente porque perseverando, põe-se a fazer vibrar outras intensidades: um "fundo sem fundo", a retirada de todo fundamento, a inexistência de toda base genética e destinal, a devastação - talvez, a inviabilidade do significado. Pense-se: para nomear o evento presumido, seria razoável que o pirotécnico também o metaforizasse sob os recursos representativos mais comuns e precisos de sua existência: fogos de artifício (cores, formas, sons); mas tal índice cromático, o "branco", embora incida forte, o tempo todo, esqueleticamente, como suposta profundeza, não tem função universalizante ou catolicizante para simplesmente simbolizar e comunicar: ele pode ser decidido como um nãosignificado, como uma imagem pura, branco que é branco, na superfície, autossuficiente, belíssima, intraduzível, indecifrável. Percebe-se, é claro, que no conto o "branco" pode apontar algum horizonte utópico, relacionado que está ao visionário e à espera, ideal que se tem, que se recria e que nunca chega; mas somente um arbítrio arbitrário, intensamente viciado em disposições pragmáticas de desmascaramento, no imperialismo que empreende proposições sobre proposições, poderia transformar o seu formato pirotécnico em "símbolo da paz”, "vinda messiânica” ou em qualquer outra proposição. Com a vela inútil, não é viável determinar significados para tal designação excêntrica nem domá-la com intervenções alienígenas, a não ser tomá-la como já-feita, literalmente (esta, com efeito, um total não-dizer: "isto é isto"); nela, apenas imaginar e imaginar, fluidamente. ${ }^{38}$

\footnotetext{
38 Não se distingue aqui imaginação e fantasia. A distinção convencional coloca a imaginação como um processo psicológico que exige uma reelaboração dos dados da realidade e a fantasia como um processo próximo ao delírio, à loucura. Tendo que não é a questão da realidade o problema da imaginação nem a da loucura o da fantasia, mas sim a questão da experiência imaginária em suas relações diretas com a imagem poética, interessa mais defini-las identicamente: reação fluída ao âmbito em que as coisas já não precisam ser pensadas em termos de significação. Já Bachelard rejeitava a tese corrente de que a imaginação consiste numa faculdade de formar imagens acerca do real: "A imaginação não é, como sugere a etimologia, a faculdade de formar imagens da realidade; é a faculdade de formar imagens que ultrapassam a realidade [...] É uma faculdade de sobrehumanidade": Gaston Bachelard, A água e os sonhos: ensaio sobre a imaginação da matéria, São Paulo:
} 
Está-se num térreo povoado de senso e não-senso; importa, pois, pensar sobre ele. Mas é preciso parar, suspender drasticamente os movimentos de pensamento anteriores, fazer brotar outros cenários de experiência e atualizar por outros meios a questão do significado e do não-significado tomada anteriormente no capítulo "Círculo quadrado": teoricamente, quando se fala de senso e não-senso é possível pensar a partir de que nível de compreensão? Desnecessário é repetir que os termos assimilam alguns dos problemas mais controversos e desnorteantes de todos os tempos (para filósofos, psicanalistas, semioticistas ou críticos literários), que há sobre eles um universo muitíssimo extenso de reflexões e que os pontos de vista ponderam diversos conceitos operantes, todos eles com feições múltiplas, em diferentes formulações: signo, significante, significado, imagem, símbolo, figura, palavra e coisa, senso comum e bom senso, senso e não-senso como sistemas ou processos, como usos, como vetores de campo, delimitados ou não pela intenção de quem fala, senso emotivo ou simbólico, pictórico ou imagético, não-senso significativo ou insignificante etc. ${ }^{39}$ Embora complexo e insolúvel, este âmbito nocional é inevitável, principalmente quando se está num horizonte de pensamento em que noções como senso e não-senso se colocam como problema (para ver o que isso implica, agora de uma forma diferente, basta pensar nos estranhos planos que se montam e se remontam em um conto como "Os três nomes de Godofredo": a internominação de um narrador-protagonista - ou seja, um “eu” - que é "ele" e "eles”, João de Deus, Robério e Godofredo, dependendo de com quem, Geralda, Joana, Isabel ou ainda uma mulher parecida com as outras esposas: embora não se veja algo que possa ser decidido como uma imagem pura, a própria sobreposição ou convivência de planos adversos que caracteriza a história introduz uma lógica alógica). Sem errar muito, pode-se definir o problema como uma das questões maiores entre as pirotecnias de Rubião. Cá, lá, no cipoal do pensamento sobre senso e não-senso, elegem-se inúmeras hipóteses, riscos: torna-se prudente pensar os termos apenas em torno de alguns tipos de abordagem, restringindo ao máximo o campo de ponderação, sem desprezar o alcance do problema, voltando-se especialmente àquelas

Martins Fontes, 1997, p. 17-8. De qualquer forma, perguntar pela relação entre interpretação e imagem é perguntar pela relação entre imaginação e imagem. Não é em outros termos que Foucault faz uma introdução ao ensaio de Binswanger $O$ sonho e a existência, texto de juventude de Foucault e ainda hoje pouco conhecido: cf. Michel Foucault, "Introdução (in Binswanger)" (1954), in Problematização do sujeito: psicologia, psiquiatria e psicanálise (Ditos e escritos - vol. 1), Rio de Janeiro: Forense Universitária, 1999.

${ }^{39}$ Para uma síntese de discussões sobre interpretação e significação em literatura e sobre a sua articulação com diferentes disciplinas, cf. Maria Antonieta Jordão de Oliveira Borba, Tópicos de teoria para a investigação do discurso literário, Rio de Janeiro: 7 Letras, 2004. Cf. também: Tzvetan Todorov, "Tipologia dos fatos de sentido", in Oswald Ducrot e Tzvetan Todorov, Dicionário enciclopédico das ciências da linguagem, São Paulo: Perspectiva, 2001, p. 235-39. 
abordagens que, de certa forma, contribuem para alguma experiência lógica do indizível em literatura.

Senso pode ser entendido apenas no âmbito nocional do "significado" ou da "significação": o que um texto quer dizer ou pode dizer - onde o que se denomina não-senso, corresponde, na verdade, a um extremo oposto que também se liga ao querer dizer, mesmo quando é somente um vir-a-ser: diz-se, assim, portanto, que tanto a insignificância significa quanto o silêncio não é quieto ou calado: senso e não-senso são, neste caso, entidades "existentes". No cinema, mesmo uma tela continuamente branca durante duas ou três horas está vulnerável às inúmeras possibilidades de significado que um espectador pode lhe atribuir; o chamado absurdo ou absurdez pode encontrar significados de absurdidade nas teias da significação, embora os parâmetros que o definem como absurdo sejam tão móveis e moles quanto os significados que lhe podem ser atribuídos: o significado é produto flutuante. Mas dizer, deste modo, que não há um significado primeiro nem último não basta: a decisão por uma imagem pura, ou por algo intransitivo, ou indizível, ou intraduzível, exige sair das redes de significado, colocar a questão num outro campo de pensamento, que não se reduza à simples afirmação da assemia, que se situe numa dimensão filosófica cujo valor lógico não seja uma "existência” nem um “corpo". É-lhe necessária outra feição de pensamento. Somente neste plano o não-senso pode ser decidido como algo irredutível. Mas como isso é possível? Tem-se já alguma oportunidade de criação conceitual: uma questão estoica por meio de uma questão deleuzeana. Senso também pode ser entendido no âmbito do "sentido", quando se distingue conceitualmente significação (dimensão empírica, atual) e sentido (dimensão do acontecimento, virtual) ${ }^{40}$, como faz Deleuze, em Diferença e Repetição e especialmente no espinhosíssimo Lógica do sentido (livro em que estão intricados dispositivos proliferantes e descentrados: séries, multiplicidades, simulacros, diferentemente atualizados ao longo das páginas), recriando uma tradição que deita raízes nos estoicos, estende-se nas antigas discussões sobre conotação e denotação e assume aspectos muito diferentes em Frege, em Meinong, em Vygotsky, em Husserl e outros. A significação, cujo valor lógico é uma "condição de verdade", discorre Deleuze, trata da relação de uma proposição (palavra, frase, discurso) com conceitos universais e gerais: remete aos conceitos e à maneira pela qual eles se relacionam a objetos (concretos ou abstratos) num determinado campo de representação; o sentido é o "expresso da proposição", aquilo que atravessa a proposição como camada virtual. São, pois, coisas diferentes: uma teoria do sentido, pensada

\footnotetext{
${ }^{40}$ A princípio, ilustre-se o caso assim: num jogo de xadrez, há uma dimensão atual (o movimento das peças, entidade existente) atravessada desde sempre por uma dimensão virtual (o xeque, entidade não-existente).
} 
de modo direto e intrínseco, não é uma teoria da significação. ${ }^{41}$ Quatro seriam as dimensões envolvidas numa proposição: designação ou indicação (referência a um "ele": relação da proposição a um estado de coisas exteriores, sob a forma "é isto", "não é isto", tendo como critério o verdadeiro e o falso), manifestação ou expressão (ato que constitui um "eu": relação da proposição ao sujeito que fala e se exprime, tendo como critério a veracidade e o engano), significação (a implicação conceitual: relação da proposição com conceitos gerais, sob a forma "isto implica aquilo" ou "isto, logo aquilo") e sentido (algo que não está nos objetos designados, não está na atividade mental daquele que se exprime e não se confunde com a significação ou com os problemas da significação). ${ }^{42}$ A designação, a manifestação e a significação pertencem ao "círculo intraproposicional", enquanto o sentido é extraproposicional (não "existe”: insiste, subsiste). Mais fácil é falar o que o sentido não é do que o que ele é: corresponde à proposição, mas é incorpóreo. Perguntar pelo sentido é perguntar por uma entidade não-existente: "o sentido é o expresso da proposição, este incorporal na superfície das coisas, entidade complexa irredutível, acontecimento puro que insiste ou subsiste na proposição". 43

Deleuze escreve que o problema do sentido foi diferentemente "descoberto" (deleuzeanamente, o filósofo não descobre: cria) três vezes: a primeira, como lékton, pelos estoicos, no século III a.C.; a segunda, como complexe significabile, por Gregório de Rimini e Nicolas d'Autrecourt, no século XIV; a terceira, como objektiv, por Alexius Meinong, no século XIX. Os estoicos, que não raramente são considerados os fundadores das tradições que se ocuparam e se ocupam com o problema da significação e do sentido, foram um escândalo na filosofia: Platão e Aristóteles, por exemplo, construíram uma filosofia do ser (e o Ocidente herdou em grande medida esse modelo); os estoicos acrescentaram à filosofia do ser uma filosofia do extra-ser ou do acontecimento (alheia ao princípio de não-contradição que, desde Aristóteles, fundamentava a verdade $)^{44}$ - assim, trataram construtivamente aquilo que Platão

\footnotetext{
${ }^{41}$ Vale destacar: em Deleuze, os conceitos ou os termos se envolvem uns com os outros, implicando, assim, campos virtuais, além de flertarem com campos de atualização. A cada encontro com um conceito ou termo deleuzeano, é preciso espreitar qual desses campos está implicado. Como escreve Micolet: "Há na obra de Deleuze um fenômeno próprio da complication [...] De acordo com uma das acepções, ela pode ser entendida como a complicação de termos diferentes, que entram em relação em vez de se excluírem ou de se justaporem": Hervé Micolet, "Introduction”, in Bruno Gelas e Hervé Micolet (orgs.), Deleuze et les écrivains: littérature et philosophie, Nantes: Éditions Cécile Defaut, 2007, p. 7.

${ }^{42}$ Cf. Gilles Deleuze, "Terceira série: Da proposição", in Lógica do sentido, São Paulo: Perspectiva, 2009. Cf. também, sem confundir agora os usos da palavra "sentido" com o conceito "sentido": Gilles Deleuze, "Sentido e proposição", "Os paradoxos do sentido" e "Sentido e problema", in Diferença e repetição, Rio de Janeiro: Graal, 2006.

${ }^{43}$ Gilles Deleuze, Lógica do sentido, São Paulo: Perspectiva, 2009, p. 20.

${ }^{44} \mathrm{O}$ assunto pode ser ilustrado de maneira simples, assim, como fez Claudio Ulpiano numa aula: um círculo é um "ser", assim como um quadrado é outro "ser" (todo corpo é um ser); mas um "círculo quadrado", constituído,
} 
chamara depreciativamente de simulacro (platonicamente, tudo o que se furta à Ideia) e romperam com a consideração aristotélica de que o que não se submete ao "princípio" necessariamente se conduz a um abismo indiferenciado. Partindo da distinção estoica entre seres (os corporais) e acontecimentos (os incorporais) e apresentando uma longa linha de pensamento que percorre a história da filosofia, Deleuze vincula o sentido ao acontecimento, atualizando-o por muitas e distintas maneiras, tendo-o também no prisma de acontecimento linguístico. Lógica do sentido apresenta uma espécie de experiência paradoxal, lógica e psicanalítica: paradoxal, porque nela o sentido é uma entidade não-existente, que guarda relações muito particulares com o não-senso; lógica, porque ela caracteriza o modo como o sentido desliza pela superfície das proposições: acontecimento-sentido; psicanalítica, porque ela mostra como, desde a profundidade dos corpos, surge essa espécie de "bolha" que vem morrer na superfície, fazendo repercutir a "pele" da linguagem, numa sucessão de linhas de fuga, até diluir-se no indeterminado: sentido-fantasma. Entenda-se, pois: o sentido se efetua passando pelas três dimensões empíricas, as intraproposicionais, atravessando-as, como que dotado de uma virtualidade, sem se confundir de modo algum com elas. Embora incorpóreo, ele é "algo". Seu estatuto é ininteligível sem a assimilação de uma nova imagem do pensamento, uma imagem que se confronte com a recognição e com o reconhecimento assentados no senso comum e no bom senso: nem formal nem informe: aformal; não ilógica: alógica. $^{45}$ Escreve Foucault, sobre essa teoria de Deleuze: "E o que vai entrar então, submergindo a aparência, rompendo suas alianças com a essência, é o acontecimento; expulsando a densidade da matéria, o incorpóreo; rompendo o círculo que imita a eternidade, a insistência intemporal; purificando-se de todas as misturas com a pureza, a singularidade impenetrável; socorrendo a falsidade do falso-semblante, a própria semelhança do simulacro". ${ }^{46}$ Deleuze saúda com um grande riso estoico a revanche do simulacro, insistindo, como sempre, na realidade do virtual: à obstinação que coloca as coisas somente em termos de significado, a sutileza opõe um non possumus inapelável, o que faz Foucault proferir, animadíssimo, neste contexto do extraordinário impacto que lhe provocara a leitura de Lógica do sentido e Diferença e repetição, o famoso vaticínio: “um dia, talvez, o século será

portanto, pelo "ser" do círculo e pelo "ser" do quadrado, é um extra-ser, um incorporal, um acontecimento (nem sequer pode ser desenhado). Outro exemplo: a árvore e o verde possuem um "ser", mas o "arvorificar" e o "verdejar" são um acontecimento. Os estoicos, amantes de paradoxos, encontram, pois, uma coisa que não "existe" como corpo, mas "insiste", "subsiste": tem propriedades lógicas.

${ }^{45}$ Neste contexto, "imagem" significa o que determina o regime de visibilidade do pensamento, aquilo que o pensamento é capaz de ver, de dispor e determinar. Cf. Gilles Deleuze, "A imagem do pensamento", in Diferença e repetição, Rio de Janeiro: Graal, 1988.

${ }^{46}$ Michel Foucault, "Theatrum philosophicum" (1970), in Arqueologia das ciências e história dos sistemas de pensamento (Ditos e escritos - vol. 2), Rio de Janeiro: Forense Universitária, 2008, p. 232. 
deleuzeano". ${ }^{47}$ Mas eis o problema filosófico para as tradições ocidentais de pensamento que não herdaram uma filosofia do extra-ser: "o sentido, deste ponto de vista, é o verdadeiro loquendum, aquilo que não pode ser dito no uso empírico e só pode ser dito no uso transcendente". 48

Por certo, a teoria do sentido de Deleuze sempre exigirá estudos e arranjos renovados. ${ }^{49}$ Mas quer-se fazer aqui não um inventário dos conceitos deleuzeanos (nenhuma pretensão nesta direção), tampouco tomá-los como chave de leitura, mas, muito deleuzeanamente talvez, criar com eles, pela semelhança e pela diferença: buscar enfim algum ponto de experiência que súbita e necessariamente já se apresente atualizado e transformado, para pensar não-senso em Rubião; mais do que estabelecer uma legalidade ou uma síntese empenhada da teoria, algum experimentum, secundariamente heterogêneo às heterogeneidades primárias. Deleuze mesmo, afinal, promove uma experimentação dos fluxos de suas ideias, procedendo por avanços e quebras, retalhos, reconfigurações, dramatizações, lençóis a serem continuadamente remexidos; assim, aliás, talvez não permita esquemas fáceis, organogramas, deleuzeanismos, discipulados, subserviências. Tenha-se como exemplo este Lógica do sentido: Carroll, que é fundamental no início do livro, perde subitamente importância a partir de seu primeiro confronto com Artaud, na $13^{\mathrm{a}}$ série de paradoxos; a diferença entre as chamadas "séries de superfície" do primeiro e os chamados "polos de profundidade" do segundo causa uma repentina atualização no pensamento deleuzeano: as superfícies carrollianas cedem espaço para as profundidades da aventura nômade de Artaud. Já se afirmou muitas vezes, entre os estudiosos de Deleuze: é impossível fazer dele um mestre, ele é uma singularidade nômade, ou uma caixa de ferramentas, ou uma dinâmica proteiforme; que seus conceitos inspirem outras coisas incide na insistência em "fazer filosofia", "criar conceitos" - e não apenas em "fazer história da filosofia". 50

O que aparece então como noção interessante para se pensar algumas pirotecnias de Rubião é que a opção se dá entre uma lógica da verdade, que toma significação como

\footnotetext{
${ }^{47}$ Cf. Michel Foucault, ibidem., p. 230.

${ }^{48}$ Gilles Deleuze, Diferença e repetição, Rio de Janeiro: Graal, 1988, p. 223.

${ }^{49}$ Cf., a propósito: François Wahl, "O copo de dados do sentido", in Éric Alliez (org.), Gilles Deleuze: uma vida filosófica, São Paulo: Ed. 34, 2000; Luiz Manoel Lopes, A teoria do sentido em Deleuze - Tese (Doutorado em filosofia), Universidade Federal de São Carlos (UFSCar), 2006; Hélio Rebello Cardoso Junior, Teoria das multiplicidades no pensamento de Gilles Deleuze - Tese (Doutorado em filosofia), Universidade Estadual de Campinas (UNICAMP), 1996; Júlia Almeida, Estudos deleuzeanos da linguagem, Campinas: Ed. UNICAMP, 2003.

${ }^{50}$ Sínteses distintas do pensamento de Deleuze podem ser encontradas em: Éric Alliez (org.), Gilles Deleuze: uma vida filosófica, São Paulo: Ed. 34, 2000; Éric Alliez, Deleuze: filosofia virtual, São Paulo: Ed. 34, 1996; Michael Hardt, Gilles Deleuze: um aprendizado em filosofia, São Paulo: Ed. 34, 1996; Alain Badiou, Deleuze: o clamor do ser, Rio de Janeiro: Jorge Zahar, 1997.
} 
elemento genético, e uma lógica do acontecimento, que, sem ignorar as dimensões corporais da proposição, incluindo o âmbito da significação, abre-se para o incorporal capaz de admitir o não-senso de uma imagem pura (ou seja, que só diz o que está dado: ela mesma, como um indizível). Numa questão estoica por meio de uma questão deleuzeana, já recriando as nomenclaturas, os conceitos e os níveis de intervenção, rodopiando agora em eixos que se compõem mutuamente, eis então o que importa: senso-significado e senso-sentido como campos de pensamento - assim, como se pega uma matéria primeira, numa geografia de pensamento primária, e já se lhe apresenta transformada ou metamorfoseada como matéria segunda, numa geografia de pensamento secundária. Sob este ponto de vista, aquela incorporabilidade do sentido deleuzeano corresponde agora à incorporabilidade do não-senso em senso-sentido: a decisão pragmática pelo não-senso sendo amparada por uma filosofia do não-existente, do incorpóreo, do impalpável, do indizível. Pense-se o não-senso a partir do corpóreo - e já não se terá em Rubião o figural (como se pode lembrar este conceito no contra-hermenêutico Discours, figure, de Jean-François Lyotard). Pense-se o não-senso a partir do incorpóreo - e já não se terá em Rubião o símbolo (como se pode lembrar o desenvolvimento deste conceito em Paul Ricoeur, por exemplo). Tem-se pelo menos duas maneiras de pensar. A totalização dos objetos se adapta à destotalização, igualmente: se um objeto pirotécnico não é imune à significação, não é imune à não-significação (sim, desde que a decisão pelo não-senso possa se amparar num campo de pensamento que ultrapasse a linguagem, que ultrapasse até mesmo a materialidade de uma operação $A=A$ ). Quando se pensa no âmbito do senso-significado, a pirotecnia é decidida como um paiol de símbolos sempre significativos, ligada de alguma forma à significação (polissemia) que remete a conceitos julgados universais e gerais (a pirotecnia se constitui por uma opacidade que enfim não se opõe absolutamente à significação: torna-se uma imagem a ser interpretada); quando se pensa no âmbito do senso-sentido, a pirotecnia é decidida como um não-significado (assemia), ligada agora à incorporalidade do não-existente, que pode ser pensada figural (a pirotecnia se constitui por uma irredutibilidade que enfim se opõe absolutamente à significação: torna-se uma imagem pura). Mas que vêm a ser o figural e o símbolo? Novamente, trata-se aqui de eleger e focar, no que é constelação profusa e incerta, apenas algumas concepções. Exclusões e desproporções são, portanto, propositais.

Lyotard entende (e generaliza) o figural como a transcendência do símbolo, algo que já não pode ser determinado pelo regime discursivo do intérprete (generaliza assim, tendo como pressuposto de crítica que a deficiência do estruturalismo teria sido exatamente pensar o 
figural em termos inteiramente discursivos): "O que é selvagem é a arte como silêncio. A posição da arte é um desmentido à posição do discurso. A posição da arte indica uma função da figura, que não é significada, e essa função em volta e até mesmo no cerne do discurso. Esta posição indica que a transcendência do símbolo é a figura, quer dizer, uma manifestação espacial que o espaço linguístico não pode incorporar sem ser abalado, uma exterioridade que ele não pode interiorizar como significação". 51 Tomando toda experiência estética como algo que possui o que escapa da hermenêutica (logo, rompe com o campo das significações) ou questionando o privilégio do discurso interpretativo, Lyotard define (e generaliza) o figural como uma espécie de aliquid - sim, da mesma maneira que autores como Merleau-Ponty, especialmente depois de se afastar de Sartre em meados dos anos cinquenta, quando se interessa sobretudo pelo vivido, pela consciência perceptiva, e Deleuze, já em seus primeiros trabalhos, tentam pensar o sensível e a sensação como pura alteridade, irrecuperáveis pela dogmática decisória do discurso interpretativo, ou como, mais recentemente, Gumbrecht desenvolve o conceito "presença", no também contra-hermenêutico Production of presence: what meaning cannot convey. ${ }^{52} \mathrm{O}$ campo da arte, ao perturbar a ordem das significações, manifesta o que escapa: ao abrir a letra, aparece a imagem; mas a imagem demanda algo que já não pode ser explicado pela letra: o figural é aquilo que se ancora numa outra natureza espacial. Diz Lyotard: "Há outro espaço, espaço figural. É preciso supô-lo escondido, que não se dá a ver nem a pensar, que se indica lateralmente, fugazmente, nos discursos e percepções, como aquilo que os incomoda". ${ }^{53}$ Tendo propriedades semelhantes aos incorporais estoicos, este "outro espaço" também se abre, pois, agora de uma forma diferente e já transformado, à ideia de imagem pura, intransitiva, indizível. O figural se torna nesta perspectiva uma espécie de pensamento impensável.

Mas não são raras as concepções de que um texto literário, especialmente um texto como os de Rubião, comporta de fato apenas a dimensão do símbolo (no fundo, a representação de alguma verdade), passível de apropriação, sendo janela no mínimo semiaberta para realidades e significações inteligíveis mediante processos de interpretação (assim, um "inteligível” se acrescentaria ao "simbólico" ou ao "sensível”). Sabe-se: símbolo

\footnotetext{
${ }^{51}$ Jean-François Lyotard, Discours, figure, Minneapolis: University of Minnesota Press, 2011, p. 7. Cf. também Helder Gomes, "Arte, experimentação e vanguarda no pensamento de Jean-François Lyotard", in Revista Filosófica de Coimbra, Universidade de Coimbra, v. 21, p. 129-161, 2002.

52 Cf. Hans Ulrich Gumbrecht, Production of presence: what meaning cannot convey, California: Stanford University Press, 2004.

${ }^{53}$ Jean-François Lyotard, op. cit., p. 129. A polissemia da palavra figura tornou-a utilizável em muitos contextos distintos. Por exemplo: em Lyotard, a figura é um princípio ativo que não é suscetível ao discurso; em Ricoeur, no entanto, a "metáfora viva" é a figura por excelência. Cf. Paul Ricoeur, A metáfora viva, São Paulo: Loyola, 2005.
} 
pode ser entendido de forma ampla demais, de modo que tudo é símbolo, ou de forma estreita demais, de modo que um símbolo só se contém, assim, a si mesmo, como nas combinatórias da lógica simbólica mais abstrata (equação do segundo grau, duas incógnitas $x$ : $\mathrm{ax}^{2}+\mathrm{bx}+\mathrm{c}=$ 0). Os matemáticos facilmente entendem símbolo como uma expressão privada de significado. Tudo começa e tudo termina no modo como se pensa um conceito de símbolo mas aí, não raramente, pelo desejo de isenção ou de não sucumbir nos labirintos conceituais, verte-se sempre alguma prudência de simplesmente condensá-lo como condensação: o símbolo é um símbolo. Maurice Blanchot, por exemplo, investe na possibilidade de que o símbolo não tem por meta senão algo que seja ele mesmo, visando o inexprimível, região sem acesso: "O símbolo tem pretensões muito diferentes. De imediato, ele espera saltar para fora da esfera da linguagem, da linguagem sob todas as suas formas. O que ele visa não é, de modo algum, exprimível, o que ele dá a ver e a entender não é suscetível de nenhum entendimento direto, nem mesmo de qualquer tipo de entendimento. O plano de onde ele nos faz partir é apenas um trampolim para nos elevar, ou nos precipitar, em direção a uma região outra à qual falta todo acesso". ${ }^{54}$ À dúvida geral sobre a função simbólica da linguagem, são notórias as tradições distintas que se reuniram em torno das contribuições de Freud, nas quais se situaram até mesmo os díspares Lyotard, de Discours, figure, e Ricoeur, de Da interpretação: ensaio sobre Freud. ${ }^{55}$ Em linhas gerais, enquanto Lyotard, numa apropriação muito peculiar da psicanálise, propõe que "a transcendência do símbolo é a figura” (algo que não pode ser discursivamente interiorizado como significação), Ricoeur propõe, ao contrário, que sempre há funções significativas, seja qual for a forma que a Coisa possa assumir, como ocorre nas formas distorcidas da linguagem onírica. ${ }^{56}$ Freud, ao trazer para o campo da linguagem tanto uma noção de inconsciente que é gramática estranha e própria (o Outro) quanto algo como uma "semântica do desejo" (na qual os sonhos e os atos da fala podem ser considerados, pelo analista, como portadores de algum significado, mesmo que este não possa ser trazido inteiramente à luz), teria descoberto que a linguagem usada para expressar o desejo, até na formulação mais ambígua, está como que carregada potencialmente de significados escondidos (logo, funções), algo a ser trabalhado através de um tipo de interpretação (logo, processos e métodos), feito especulação no nível oculto do discurso aparente. Com Freud, o sonho teria retornado ao campo da significação: de não-senso puro a senso do inconsciente. Daí se ter que, em literatura, semelhantemente, mesmo o não-senso seria da ordem de

\footnotetext{
${ }^{54}$ Maurice Blanchot, O livro por vir, São Paulo: Martins Fontes, 2005, p. 126.

${ }_{55}^{5}$ Cf. Paul Ricoeur, Da interpretação: ensaio sobre Freud, Rio de Janeiro: Imago, 1977.

${ }^{56}$ Para uma síntese do pensamento de Ricoeur, cf. David Pellauer, Compreender Ricoeur, Petrópolis: Vozes, 2009.
} 
símbolos que se inclinam ao campo do significado quando interpretados: os mecanismos das significações passariam pelo não-senso. O texto manifesto seria uma camuflagem mascarando a autêntica significação - esta, somente revelável pela descoberta do significado latente. Os símbolos teriam, por assim dizer, espessura e opacidade, mas seriam fonte de um dinamismo inerente: nos símbolos, a invenção e a descoberta não se oporiam (embora seja razoável colocar, aqui, como dúvida, pense-se: primeiro, se tal "invenção" não obedeceria, como no Outro, uma lei que lhe é totalmente própria, mas como gramática intransponível; segundo, se tal "descoberta" também não comportaria, aqui, acolá, acidentes simbólicos muito parecidos aos que ela pretendeu descobrir). À leitura de Freud por Ricoeur, contudo, pode-se dar uma resposta primitiva e funcional: a análise freudiana ocorre apenas na função semântica, deixando na sombra tanto a arquitetura morfológica e sintática da Coisa quanto a dimensão propriamente impensável da Coisa. De qualquer forma, a distância entre significação e imagem pirotécnica não é jamais totalizada por uma interpretação analítica: há sempre uma bifurcação. Ou seja, assim como o sonho trai a significação tanto quanto a potencializa, pois a investe de tantos contrassensos quantos forem necessários para cobrir toda a superfície do domínio onírico $^{57}$, a pirotecnia em literatura trai a significação tanto quanto a potencializa: a plástica imaginária da pirotecnia, com os significados que nela se decidem, não é senão a forma de um paradoxo. Escreve Foucault: "Na origem dessas faltas da teoria freudiana, há, sem dúvida, uma insuficiência na elaboração da noção de símbolo. O símbolo é tomado por Freud somente como ponto de tangência onde vêm se encontrar, por um instante, a significação límpida e o material da imagem tomado como resíduo transformado e transformável da percepção". 58

Não é preciso absorver absolutamente todos os contornos e potenciais desses conceitos nem acolher toda cobertura que eles têm nesses pensadores para se pensar o problema que existe em alguns dos contos mais fortes de Rubião: premissas e pontos fundamentais já são suficientes para se sugerir e combinar bem, de formas distintas, alguns elementos. Aqui, pois, observa-se o assunto numa perspectiva coincidente e ao mesmo tempo não coincidente, com alguma liberdade. Proponha-se, a princípio, assim, como mix sumariante, por Deleuze, Lyotard e Ricoeur: senso-sentido, no figural; senso-significado, no símbolo. Também: nãosenso como figural, no senso-sentido; não-senso como símbolo, no senso-significado.

\footnotetext{
${ }^{57}$ Cf., nisto, Michel Foucault, "Introdução (in Binswanger)" (1954), in Problematização do sujeito: psicologia, psiquiatria e psicanálise (Ditos e escritos - vol. 1), Rio de Janeiro: Forense Universitária, 1999 (especialmente, p. 68-73).

${ }_{58}$ Michel Foucault, ibidem, p. 72.
} 
Portanto, está-se distinguindo senso-significado e senso-sentido, mantendo os termos, mas agora somente como campos de pensamento. Dá-se, então, que uma pirotecnia pode ser decidida como algo inerente ao senso-significado (espaço simbólico) e como algo inerente ao senso-sentido (espaço figural). No uso dos termos, é possível transitar no âmbito corporal do senso-significado ou no âmbito incorporal do senso-sentido, no espaço do símbolo ou no espaço da figura. Mas, em Rubião, o que pensar? Tem-se aqui como percepção que a obsessão pelos significados em alguns contos rubianos é semelhante à obsessão de Elifaz, Bildade e Zofar em torno do sofrimento de Jó, aquela busca repetitiva de motivos feita sob o provável auspício da justiça retributiva de Deus: deve haver algum significado, precisa haver algum significado, não é possível não ter significado, tudo tem significado (é claro, o caso adquire relevância filosófica e linguística na medida em que se assemelha à proliferação na qual um significado nunca se confirma nem encontra termo; pode-se lembrar neste ponto do chamado "paradoxo de Frege", já aludido aqui em "Círculo quadrado": $x$ leva a $x$ ', que leva a $y$, que leva a $y^{\prime}$, que leva a $z$ etc.). A horizontalidade do térreo permite outro tipo de copresença intrínseca. É ela: senso-sentido e não-senso (e não "senso-significado e não-senso"). Aí, o não-senso se torna irredutível, estoicamente. Nesse aspecto, também a ideia "símbolo" (como se lê, assim, em alguns tipos de interpretação, Cris, o perseguido em "A lua", simbolizando no próprio nome o cris(tão) ou a imagem tida pura e inocente de Cristo: Cris, lua e luz; embora, paradoxalmente, em senso-significado, seja possível ver no nome próprio a dimensão do adjetivo "cinzento", "gris"), ou seja, a ideia concebida como "cifra", "sinal” ou "código" original e prioritário, diretamente significativo, em situação, com valor evocativo, como um dia os símbolos da terra refletiram o céu ou o inferno, atrelados à possibilidade de se construir a partir deles uma gramática substancialista e totalizante, perde-se: é razoável pensar que símbolo é coisa sempre deslizante, cada vez não coincidente, também plural, justamente porque sob contraditórias ordens temporais de cultura, como que a se pôr também entre nuvens, ou numa "região sem acesso", como pensa Blanchot (mas se fale "figural", quando se vendo a questão em termos do intraduzível, optando por termos). Ultrapassa-se assim o espaço do "símbolo que significa": cada coisa, dessas pirotecnias rubianas, torna-se em si mesma não uma coisa que se oferece apenas à significação, mas uma coisa que pode ser decidida como não-senso. Algo intransitivo, indizível ou figural, que não deve ser interiorizado como significação, escapa do regime discursivo interpretante que sonha o fim do jogo, assim como escapa daquele que sonha um jogo sem fim (em senso-significado, sempre há interpretações monossêmicas que se põem como irrefutáveis ou finalistas e sempre há 
interpretações polissêmicas que se põem como refutáveis ou provisórias). Gestar o símbolo em profundidade, como signo dos signos, ou tê-lo em investigação, como se nele morasse a grande verdade, material ou ideal, como se nele estivesse tudo o que é pertinente, é, como escreve Foucault, num contexto mais amplo, a própria morte da interpretação: “A morte da interpretação é acreditar que há signos, signos que existem primeiramente, originalmente, realmente, como marcas coerentes, pertinentes e sistemáticas. A vida da interpretação, pelo contrário, é acreditar que só há interpretações". 59

Eis então o que importa, numa decisão pragmática que já reinventou a nomenclatura e o conceito: senso-sentido, não-senso, figural. Trevas dissipam luz (além do símbolo, como as pétalas que são apenas pétalas, insignificantes), corroem pela base as redes de significado, tornando inviável o fazer e o decidir se existe um segredo, ou nenhum, ou vários. Em "A flor de vidro", a mesma decisão, no mesmo impasse: embora se procure algumas coordenadas que possam estar contidas na relação de Eronides com Marialice (como se verá logo adiante), dizse que não se deve transitar firmemente em significados para tal flor de vidro. À medida que a narrativa avança, os mergulhos em alguma ideia de símbolo (altura ou profundidade) são engolidos por um movimento lateral (superfície) em que hipotéticas cenas-mensagem são sabotadas pela potência da pura imagem - este, o pendor (e o esplendor) de toda literatura moderna à invenção de algo indizível. No que tal intransitivo, indizível ou figural pode ser visto como a mais alta finalidade de algumas pirotecnias rubianas, elemento pesadíssimo, caiba-se que o térreo remete aqui ao que é indiscernível. Conhecem-no bem leitores de acasos, de espécies híbridas, carrosséis, caleidoscópios, partículas subatômicas. Nele, a pirotecnia parece não poder corresponder senão ao "sem pé nem cabeça" de uma organização alógica, essencialmente silenciosa, indisposta à interpretação. Como se pode dizer: as pétalas em Belinha, tão insubmissas ao poder da luz elétrica, não são um símbolo que em sensosignificado ampara inúmeras significações, mas não-senso, vinculado ao senso-sentido, como figural, muito. Também toda a história se torna apenas um excesso de esquisitice, não se deve dar a ela uma resposta: a Coisa quer-se Coisa, a ser lida literalmente, imaginada excessivamente. Se tomada pelo esforço interpretativo por significação (pois a busca pelas significações é própria de uma concepção de complemento que não tem a Coisa como completa e que, portanto, põe-se como complemento da Coisa), sua pele pouca e muita foge,

\footnotetext{
${ }^{59}$ Michel Foucault, "Nietzsche, Freud, Marx" (1967), in Arqueologia das ciências e história dos sistemas de pensamento (Ditos e escritos - vol. 2), Rio de Janeiro: Forense Universitária, 2008, p. 50.
} 
some, escafede-se - como que a desfazer-se tristemente do forte paradoxo valeryano "o mais profundo é a pele".

De outra forma, assim, tudo o que se exclui da explicação laboratorial, incondicionado: pétalas que são pétalas, branco que é branco, flor de vidro que é flor de vidro etc. Como problema delimitado e pressuposto de experiência, não o senso-significado em que a pirotecnia é sempre significativa (móvel, mole, veloz), mas o senso-sentido em que a pirotecnia é figural (pura, intransitiva, indizível). Tal é o térreo em algum Rubião: potencialização de uma superfície, chuva chova ou lua lue, imagem pura, insignificância, figura (e não significados a serem tomados às profundezas do símbolo). É assim que esta literatura, amparada numa filosofia do não-existente, afastando-se de atribuições que lhe podem ser prescritas pelos repertórios dinâmicos e flutuantes do leitor (processo de relações: proposições primárias e secundárias), estabelecendo virtualmente polos positivos e negativos, quer-se em curto-circuito e cessa de se deixar passivamente atravessar por decodificações: desprende-se da regulação, libera-se, como que a se deixar num vácuo resistente à constatação. Mas, aqui, já é importante destacar a impotência da linguagem crítica: a própria operação sintática (ou formulação de pensamento) "pétalas que são pétalas", "branco que é branco" ou "flor de vidro que é flor de vidro" não é menos do que uma operação problemática, pois pode servir de memória às operações feitas nas bases da significação: num recorte espaço-temporal definido, ao invés de significar $a$ por $b(\mathrm{~A}=\mathrm{B})$, estaria significando $a$ por $a(\mathrm{~A}=\mathrm{A})$. Diga-se que ela é apenas a operação algebricamente "dizível” sobre o indizível (o não-senso, quando pensado em termos de senso-sentido, é algo interdito ao uso ordinário da linguagem). O ideal seria nada dizer, silenciar, imaginar: diante das imagens puras, nenhuma operação sintática, nada que pudesse ser discursivamente interiorizado como significação (eis aqui o problema que ocupa Lyotard, problema no qual se contorce todo o pensamento crítico: enquanto o não-dizer artístico exige um não-dizer crítico, o dever crítico exige uma linguagem crítica: daí que o crítico decida o não-significado pelo insuficiente ou impróprio). Obviamente, a operação sintática se resolve também em não-senso: as proposições (pétalas que são pétalas, branco que é branco, flor de vidro que é flor de vidro etc.) não devem ser pensadas em termos de significação; são, por assim dizer, um não-senso crítico que empiricamente corresponde ao não-senso artístico: a identidade não-significativa $\mathrm{A}=$ A torna-se admissível - de fato, como um signo vazio. Se os limites do significado são exatamente os limites da linguagem, o que decide o destino do não-senso crítico, ultrapassando os limites do significado crítico, ultrapassa os da linguagem: virtualmente, o 
próprio não-senso crítico se torna espelho do não-senso artístico, como um pensamento impensável.

Em alguns contos, certa vagueza narrativa, liberdade imagética ou abstracionismo lírico promove um jogo tão vulnerável à aproximação e resistente à solução, que enceta díspares experimentações, como ocorre em literatura saborosa: o dar-se ao infinito, conceito inexaurível, como se pensa o trânsito do alfa ao ômega, e o dar-se ao micro, ao nano, ao minúsculo, às dimensões quânticas, em que a aleatoriedade é plausível. Leia-se melhor o conto "A flor de vidro" (agora, nele, rentemente, usando algumas páginas: uma experiência microscópica), esta espécie interessante de narrativa breve que, aproveitando expressões gerais de Sérgio Milliet, J. Guimarães Alves e José Augusto Carvalho, poderia ser chamada de "poema em prosa", "conto poético", "poesia em prosa" - ou, como preferiu Arrigucci, "conto misterioso e belo". ${ }^{60}$ A narrativa é toda feita de impactos sentimento-olho-objeto, de signos interconexos, memórias, impressões, projeções, que, a despeito do lirismo e da linguagem econômica, opõem-se tanto à trivialidade amorosa quanto, enfim, à noção restrita ao senso-significado. Na nostalgia de Eronides, ausência parece presença: Marialice se insinua pelos campos, seu sorriso brinca na face de outras mulheres, escorre pelo verniz dos móveis, desprende-se das paredes do casarão, acompanha o trem de ferro: A máquina soltava fagulhas e o apito gritava: Marialice, Marialice, Marialice. A última nota era angustiante. Quando ela efetivamente chega num trem, de férias, anunciada previamente pelo grito de Rosária, a velha empregada, ele coloca uma venda negra numa "vista inutilizada" e passa uma navalha no resto de cabelo que lhe rodeava a cabeça. O narrador traduz a primeira impressão dele ao reencontrá-la: ela, apesar de seus trinta anos, parece ter vinte e dois (trinta menos oito). Eles se abraçam e se beijam longamente. Eronides (gr. Eros e ides: descendência de Eros) entende que Marialice veio para sempre (destarte, como se pode pensar o anseio por uma totalidade do ser, no mito da unidade quebrada); diz isto, contudo, comedido, logo, num rápido crédito sentimental à véspera: Preferiu responder à sua maneira: - Ontem pensei muito em você. Plenos, eles gastam os dias seguintes em passeios pelo campo. Num destes, quando ele, num gracejo, corre e desaparece entre as árvores do bosque, Marialice impreca: - Tomara que um galho lhe fure os olhos, diabo! Do bosque, ele traz uma flor azul, que ela aceita, beijando-o rapidamente. Brincam, pelejam: neles o amor se nutria da luta e do desespero. Mas um dia ela parte: já na estação,

\footnotetext{
${ }^{60}$ Davi Arrigucci Jr, Outros achados e perdidos, São Paulo: Companhia das Letras, p. 310.
} 
sacode um lenço branco para ele pela janela do trem. Eronides volta para casa, solitário, e um galho lhe cega a vista.

Como uma das diversas possibilidades de leitura, pense-se aqui o caso como um arranjo que contempla ausência e presença (o que é simples escolha, sem nenhuma pretensão de legalidade, de fundar uma verdade ou de atingir uma suposta "totalidade" do objeto). Sem nenhuma ingenuidade: desta busca por significação, querer-se-á, na verdade, decidir e sublinhar a não-significação da imagem pura. Em primeiro lugar, ausência que era forte presença: no texto, a dinâmica dos verbos insinuar, brincar, escorrer, desprender-se e acompanhar no primeiro parágrafo - que por aglutinação, sequenciamento e reiteração do lugar-comum "presença” combina um modo gradual de fabular Marialice - dispondo-se como que num crescendo (presença, mais presença, superpresença), da mesma forma que, musicalmente, poderia se aplicar uma progressão em um trecho cuja intensidade sonora devesse aumentar. Entre o que se percebe como presença, a ideia de sorriso que impregna as coisas (outras faces, móveis, paredes do casarão, trem de ferro) se sobrepõe à ideia de movimentos que apenas se insinuam pelos campos, por maior ênfase, repetição descritiva, materialidade: à mera insinuação, o sorriso brinca, escorre, desprende-se, acompanha. Como efeito intensivo, esta fixação material do sorriso ultrapassa aquela sutileza dos movimentos, ampliando o rosto da mulher, nas coisas, como presença já muito evidente. Ouve-se aí, então, o nome deste rosto, em espécies flagrantes de brados que figuram presença, como um painel de ruídos e notas manifestas: diz-se que o trem de ferro soltava fagulhas e o apito gritava algumas vezes o nome "Marialice", até uma última "nota angustiante". O trecho, que de início parecia propor uma reflexão sobre a modalidade da presença em termos visuais, propõe agora esta presença em termos auditivos. Por enquanto, fica ao leitor esta incógnita da "nota angustiante", que poderá ser proporcionada à frente como algo já ligado a um projeto sempre assombrado pela frustração. Grita-se, sim: Rosária (cuja obviedade do nome precisa incomodar enquanto sintonia à flor substancial) anuncia a chegada efetiva da mulher esperada gritando também o nome: - Marialice! A não ser pela mudança do tempo verbal, que agora seguirá no pretérito perfeito, pela ausência de dois pontos após a expressão "nota angustiante" e pela evidência do travessão incluído antes do nome exclamado em única linha, não se faz transição entre um possível nome gritado na última nota do apito e o nome que Rosária grita:

A máquina soltava fagulhas e o apito gritava: Marialice, Marialice, Marialice. A última nota era angustiante.

- Marialice!

Foi a velha empregada que gritou e Eronides ficou sem saber se o nome brotara da garganta de Rosária ou do seu pensamento. 
O nome da mulher, isolado, ocupando toda a linha, fica, assim, suspenso, entre dois blocos de frases, deslizando, servindo-os. Sem abolir o liame entre os gritadores, ponderando-os justapostos, em abrupta passagem, o texto instaura para o leitor este eco, este campo acústico terminante: grita-se o nome aqui como se gritava ali, retumbando um fato expressivo: o grito do apito do trem (ausência que se quer presença), o grito de Rosária (anúncio efetivo da presença).

Vai-se da superfície a um possível fundo, sempre um passo além: tal qual a hipótese da presença fora valorizada por fora, como "espetáculo", "sensação", "aparência", é valorizada agora como "perturbação" e "dúvida", por dentro, internalizada. Eronides já não distingue acontecimento e pensamento: Foi a velha empregada que gritou e Eronides ficou sem saber se o nome brotara da garganta de Rosária ou do seu pensamento. Por que já este domínio transacional do grito? Duas cadeias de percepções aparentemente incompatíveis estão constituídas e exclamadas: uma, engendrada pela ideia de grito "exterior", anunciativa, dependente do ouvido, qualificase como expressão: - Marialice!; outra, ligada ao "interior", responsiva, regida pelo pensamento, qualifica-se de imediato como impressão: - Sim, ela vai chegar. Ela vai chegar! A junção de atributos sensórios em sinestesia é um caso particular de se arriscar em polaridades: o que se ouve, o que se pensa, sem se definir. O centro deles em Eronides é o conjunto dos efeitos simples das associações, ideias gerais, substâncias, relações, postas em circulação por meio deste mecanismo súbito de revezamento da expressão e da impressão que parece reconciliar as incompatibilidades do que se ouve com o que se pensa. A situação é semelhante àquela que se dará adiante, quando Eronides pensará ter divisado a flor de vidro no alto de uma árvore: a flor como expressão do que já pode se revelar à visão, o pensamento como impressão fluente: o que se pode ver, o que se pode pensar, sem se definir.

Tem-se de qualquer forma para Eronides uma alteração no centro de gravidade: transição do que antes era simples fabulação de uma saudade (movimentos dela pelos campos, sorriso nos objetos, nome no apito do trem) para o que agora se torna uma realidade inesperada, que sacode seu corpo com violência. À potência do reencontro iminente, a potência dos gestos velozes: dele, que se lança pela escadaria abaixo, empurrado por uma alegria desvairada, que corre para encontrá-la, atingindo rapidamente a várzea; dela, que salta do vagão e o abraça demoradamente: - Oh, meu general russo! Como está lindo! Na zona do reencontro, Marialice é essencialmente corpo; Eronides, um óculo que a detecta em altíssima conta: Não envelhecera tanto como ele. Os seus trinta anos, ágeis e lépidos, davam a impressão de vinte e dois - sem vaidade, sem ânsia de juventude. No que o narrador onisciente formula aqui como primeira 
percepção de Eronides, note-se que o que se proporciona é constituído por lisura estática: visão do corpo, somente, que Eronides provavelmente não conjuga como opinião pessoal, mas como uma percepção geral e válida. O balanço transversal entre a mobilidade inicial (ser sacudido, lançar-se, correr, saltar) e os robustos gestos e sentimentos (alegria desvairada, abraços demorados, apertados, beijos longos e úmidos) premedita o sorriso dos amantes, a união dos corpos, à noite, integralizados, em perfeita conformidade: A noite surpreendeu-os sorrindo. Na plenitude dos amantes, insuficiente parece ser a força de algum acontecimento incômodo ainda preso à memória (como, vê-se, Dagô, alguém que se relacionara com Marialice): Os corpos unidos, quis falar em Dagô, mas se convenceu de que não houvera outros homens. Nem antes nem depois. Sem resistências, o prazer transborda, excelso, e decanta o que é desconfortável: nem sequer as moscas de todas as noites, que sempre velaram a insônia de Eronides, aparecem.

Encontra-se imediatamente depois um ponto nevrálgico: Acordou cedo, vagando ainda nos limites do sonho. Olhou para o lado e, não vendo Marialice, tentou reencetar o sono interrompido. Pelo seu corpo, porém, perpassava uma seiva nova. Jogou-se fora da cama e encontrou, no espelho, os cabelos antigos. Brilhavam-lhe os olhos e a venda negra desaparecera. Pergunte-se, no que a história permite: o conto recebe aqui um apêndice temporal (uma espécie de movimento retroflexo que, como um efeito flashback, recupera e detém agora apenas acontecimentos muito anteriores aos eventos recentes) ou esta manhã em que Eronides acorda cedo é a manhã imediatamente seguinte à noite em que os corpos estiveram unidos? $\mathrm{Na}$ primeira hipótese, considera-se que a jovialidade do corpo é, agora e logo depois, o signo denunciativo de pretérito - ou seja, que designa a personagem na juventude, a personagem ainda jovem -, mesmo que já exista aí em Eronides um tipo de percepção e de qualificação somente possível através de parâmetros necessariamente retrospectivos, parâmetros que vão do "depois" ao "antes", a saber: "antigos" e "desaparecer". Nisto, o leitor ainda terá que encontrar respostas razoavelmente convincentes ao elemento "noite anterior" que surge adiante: Agarrou-a com sofreguidão, desejando lembrar-lhe a noite anterior. Poderá dissertar, com liberdade e elasticidade, que esta referência temporal aponta, neste caso, para uma noite anterior qualquer, da época de juventude, uma noite inserida em algum período de férias em que a ainda jovem Marialice estivera presente. Justificará como pretérito, aqui, assim, logo: em Eronides, tanto os "cabelos antigos" (como suposta precedência aos cabelos ralos) quanto os "olhos brilhantes", ainda ilesos (como suposta precedência à vista inutilizada); em Marialice, já em seguida, tanto os "dezoito anos" quanto o "corpo esbelto" (como supostas precedências à derradeira idade de trinta anos): Contemplou-a maravilhado, vendo-a jovem e fresca. Dezoito anos rondavam-lhe o corpo esbelto. Ela, dezoito 
anos (trinta menos doze). Justificará também, por aí, o que ocorre depois da partida de Marialice, no final do conto, a vista de Eronides cegada por um galho - de modo que pela suposição deste apêndice temporal possa tomar, no conto, o fim pelo começo e o começo pelo fim, solucionando, mais ou menos, por duas ou mais partes, as pendências, assim, desde o início do texto: aquela ausência de Marialice, que um dia partiu num trem sacudindo um lenço branco; aquela "vista inutilizada", que um dia um galho feriu; aquele Eronides mais velho, com cabelos ralos, que o passar dos anos, o tempo, quis - depois, nesta direção, até o fim da história, que estaria nesta forma no meio do texto, o reencontro na estação, os beijos, os abraços e, para acabar, a noite dos corpos unidos. O problema é que esta leitura, que pressupõe soluções pelo movimento retroflexo colocado a partir desta manhã em que Eronides acorda cedo, desconsidera o que se mantém, no texto, como ideia de consciência temporal na personagem, ideia que permite a Eronides ter a convicção de que doze anos foram desfeitos, apagados, evaporados, subtraídos: Agarrou-a com sofreguidão, desejando lembrarlhe a noite anterior. Silenciou-o a convicção de que doze anos tinham se esvanecido. Se não se está na manhã imediatamente seguinte à noite dos corpos unidos, se a partir de agora o conto anexa um período da juventude, como explicar então que a personagem possa se referir à "noite anterior" e esteja tomada por esta convicção em que mensura a ideia "doze anos"? O que silencia Eronides, afirme-se, é uma convicção que não pertence aos anos de juventude: este princípio ou certeza sobre "doze anos esvanecidos", assim como os parâmetros "antigos" e "des-aparecer", pode se constituir exclusivamente por posterior arguição, na presente maturidade - este, sim, o momento apto para se distinguir um "novo" de um "antigo", um “aparecer" de um "des-parecer", um "zero ano" de um "doze anos": afinal, pense-se, algo pode ser designado em dado instante somente se o instante já estiver atravessado pelas porções, habitado pelo passado e pelo presente, pelo "antes" e pelo "depois". Diga-se, então, pela segunda hipótese: o conto muito provavelmente segue em linha reta, do passado ao futuro, num tempo linear progressivo que pode admitir aqui a ideia de "seiva nova" (como algo que é novidade, como algo que acaba de se manifestar no corpo), transfigurações corporais, convicções sobre elas. O leitor deverá lidar com a ideia de que algo inaudito transfigurou o corpo de Eronides exatamente na manhã seguinte (ressurgimento dos cabelos antigos, olhos brilhantes), fantasticamente. Como valor retrospectivo e prospectivo, aí, esta "seiva nova": supressão dos resquícios da ausência, na transformação gerada pela presença. Nela, uma disposição lógica que se permite não como dimensão de uma coisa nova qualquer, mas como formulação e ampliação metafórica sobre o que se configurou, no dia anterior, 
como reencontro, unidade, sorrisos, corpos unidos. Daí que já se dê, nele, por oposição, um apagamento dos efeitos intrínsecos à ausência (a vista inutilizada, a falta de cabelos). A calvície e o olho inútil, disfarçados antes da grande noite por uma navalha e uma venda negra, transfiguram-se de manhã em fartos cabelos, pode-se pensar, e em olhos que brilham, cada vez mais, acentuadamente, para uma percepção inflacionada: o corpo de Marialice deslocado, como que em um sítio temporal diverso, subtraído em idade: dezoito anos. Esta matemática subtrativa, afinal, já se tornara possível no primeiro momento do reencontro, na estação, quando Eronides percebera que ela não envelhecera tanto como ele. Os anos ágeis e lépidos de Marialice se transformaram ali em vinte e dois - agora, em dezoito. O âmbito das aparências, tal qual se coloca uma situação por vistas transfiguradas, porosas à iluminação, potencializa modos e disposições, ainda que se vele de certa forma pelo manto do mistério: parece ser agora uma questão de olhos, que, como já se sabe, por uma leitura que busca concordâncias, veem o que Eronides sente: na ausência, aqueles movimentos que se insinuavam, o sorriso de Marialice que brincava, escorria, desprendia-se; na presença, essas aparências superfaturadas, trinta menos oito, menos doze, toda a parafernália que constitui um modo sublime de ver Marialice.

Ei-los, então, novamente juntos, idílicos, em passeios: O roteiro era antigo, mas algo de novo irrompia pelas suas faces. A manhã mal despontara e o orvalho passava do capim para os seus pés. Os braços dele rodeavam os ombros da namorada e, amiúde, interrompia a caminhada para beijar-lhes os cabelos. Nada mais previsível ou trivial. Poder-se-ia prever que, em linha reta, o conto perdesse alguma tensão desse ponto em diante. Mas paira a imagem posta desde o título: flor vulnerável, fácil de esvair, frágil - o cair das pétalas, o estilhaçar do vidro. A imagem contém tensões em miniatura dentro de si mesma: subtende-se, nesta proposta de leitura, uma unidade, refeita pela presença de Marialice (corpos unidos), mas uma unidade débil: flor - pense-se "isto", como se aponta um $b$ em um $a$, talvez presença-flor, sendo a flor já a tosca imagem da presença - e vidro - pense-se "aquilo", um caso em uma figuração, sendo o vidro talvez já o espectro da ausência. Difícil é concluir que Marialice veio para sempre: há sem cessar um rastro, um resíduo, uma espuma em que presença transparece ausência; presença, forte ausência, flor de vidro, o tempo todo. Na primeira frase do conto, o narrador já oferecera ao leitor este campo transparente e frágil do vidro - Da flor de vidro restava somente uma reminiscência amarga -, a modo de tornar imediatamente sensível algo que, representativamente, relacionado a uma experiência anterior, restava então "somente" (mas "ainda") como uma reminiscência amarga: tinha-se, então, uma sugestão do que, entredito, poderia recrudescer. O campo semântico do pretérito imperfeito restava não fugia à ideia: sobra, mas também, como se pode 
prever, ameaça. É interessante notar que os "campos" por onde então os movimentos de Marialice se "insinuavam” foram descritos como às vezes verdes, também cinzentos: volúvel, este espaço em dupla forma sugeria, de relance, uma dramatização de polos diversos - como se diz, assim: sob a intimidação de qualquer coisa proeminentemente móvel, verdes e cinzentos. Também o grito de Rosária, na medida em que se proporcionou, no texto, como extensão ou eco de uma "nota angustiante", sugeria certo desconserto. Depois, está-se sempre no susto, como algo que se compõe na instabilidade: no reencontro, a questão das aparências físicas, a ideia de envelhecimento e juventude, liame de inseguranças; na indagação sobre o que fizera na ausência, a resposta tímida e desproporcional de Eronides, como que por defesa, precaução, resguardo - - Ontem, pensei muito em você -; à noite, a lembrança de certo caso delicado, o caso Dagô, e a alusão às moscas de todas as noites, sempre sombras de insônias, que não vieram desta vez, conservando-se, no entanto, como espectros; no dia seguinte, como Eronides, ao acordar, já não vê Marialice na cama; depois, ao abrir a porta, como a vê (assim, ausência e presença, aos bocados). Também a materialidade fragmentada do texto (parágrafos breves, pequenos blocos de frases intercalados por espaços em branco) e as referências avulsas, incompletas, soltas - A noite surpreendeu-os sorrindo. Os corpos unidos, quis falar em Dagô, mas se convenceu de que não houvera outros homens. Nem antes nem depois. ou o parágrafo solitário As moscas de todas as noites, que sempre velaram a sua insônia, não vieram. -, que insinuam experiências sem retomá-las em seguida ou sem conectá-las a um propósito relevante da narração central, figuram fração, sobras, pétalas, cacos. Por que este Dagô e estas moscas aí, senão para indicarem peças soltas? Uma reflexão sobre os miúdos pedaços poderia conduzir o leitor à prática de uma leitura do intervalo, que os duplicaria e os suportaria: poderiam soar como espécies de hipertextos, janelas de uma configuração aberta ou expansível que em lugar de um prolongamento linear fariam o leitor conjecturar sobre a dissolubilidade de sequências associativas. Nos gestos mínimos, a instabilidade também está no susto de recíprocos abandonos e distanciamentos - Largou-a na orla do cerrado e penetrou no bosque. Exasperada, ela acompanhava-o com dificuldade:-Bruto! Ó bruto! Me espera! -, desaparecimentos - Eronides desapareceu por entre as árvores. -, fugas repentinas - Eronides avançou para abraçá-la, mas ela escapuliu, correndo pelo campo afora. Os atos "largar", "desaparecer" e "escapulir" se somam à expressão do processo interno. Admite-se, por todo arranjo, a existência de um projeto assombrado pela frustração, como um fazer que se desfaz, destino desse amor que se alimenta da luta e do desespero, esta potencialidade agora da ausência na presença, o modelo inicial invertido: reencontro que hipostasia despedida, ligação que prediz súbita ruptura, espectro patente. A 
vulnerabilidade do amor parece funcionar, portanto, como coexistência não-pacífica de duplas formações imaginárias: Maria e Alice, "isto" e "aquilo", presença e ausência, encontro e desencontro, unidade e rompimento, feito os trilhos paralelos do trem que traz e leva Marialice.

Se os olhos de Eronides veem o que ele sente, toma efeito de significado a transfiguração operada pela presença da amada: de olho inútil, que, singular, ferido, como que contido semanticamente num guerreiro - Oh, meи general russo! -, apenas fabula por uma saudade e é disfarçado com uma venda negra, à olhos brilhantes, na maximização, abertos, como que inteiros, agora no plural. Alcança relevância o praguejamento de Marialice no bosque - - Tomara que um galho lhe fure os olhos, diabo! -, esta forma sagaz de ressuscitar e alvitrar o espectro, assim como ganha altitude, depois, a cena final - Na volta, um galho cegou-lhe a vista. -, a forma peremptória da concretização: assim que o trem com Marialice se põe em movimento, levando-a, e assim que a presença da flor de vidro se revela imediatamente, a vista fica novamente inútil. Tem-se, periodicamente, em ciclos: na ausência, o olho inútil; na presença, os olhos que brilham; no praguejamento, a ausência como espectro; na nova ausência, a vista outra vez cegada - de fato, a conhecidíssima ideia de "indestrutível repetição cíclica" confessada pelo autor em entrevistas. E aqui já se instaura uma teia de concordâncias e interconexões que compete ao leitor preencher, analogias que gritam para serem completadas - não a partir, é claro, de uma comutação definida entre o abstrato e o concreto, mas a partir de absorções, talvez contraditórias, das pistas disparatadas, da lâmina metafórica onde se fizeram trilhos paralelos: cabelos ralos e cabelos fartos, olho inútil e olhos brilhantes, flor azul e flor de vidro, ausência, presença, os trilhos paralelos, como aderentes e repelentes. É esse, afinal, o papel geral que um Ingarden ou um Iser atribuíram ao leitor: preencher as lacunas que um texto literário propõe como provocação, tornar determinados alguns dos locais de indeterminação. ${ }^{61}$ Os polos limitam os significados e ao mesmo tempo os expandem, permitindo um modelo especial dentro de certo sistema de interpretação: uma narrativa de interação de formas que geram outras formas. Pelas seguidas associações e pelas conexões estabelecidas, cada leitor construirá aí uma pertinência diferente: alguma coisa tida como dada, para que se possa responder a ela, com a qual certo evento poderá ser determinado por eventos anteriores e posteriores.

${ }^{\mathbf{6 1}}$ Cf., por exemplo, Roman Ingarden, The cognition of the literary work of art, Evanston: Northwestern University Press, 1973, e Wolfgang Iser, O ato da leitura: uma teoria do efeito estético, São Paulo: Ed 34, 1996. 
Eis a flor de vidro, que já uma descrição minuciosa desses sentimentos entre os amantes não poderia dizer-melhor, como o que a própria máquina-conto pode permitir em sensosignificado. Tudo bem, até aqui. Contudo, a questão é: no conto, até quando isso funciona? Comumente se diz que em Rubião o tratamento de certos temas prescinde da linguagem direta e objetiva para se compadecer com o pensamento simbólico, mais apropriado no sugerir do que no descrever. Afirme-se, no entanto, que tal "pensamento simbólico" quase nunca visa sugerir determinadamente alguma coisa apreensível: dá-se a um modo paradoxal de abertura e fechamento, por apontar e desapontar. Pirotecnia: há sempre uma mola que escapa; há sempre uma peça que, na máquina, explode. No conto "A casa do girassol vermelho", do ventre de Belinha surgem pétalas de um minúsculo girassol; em "A lua”, uma lua sai do corpo magro. Os eventos e as imagens se tornam em algum momento, como que por vinco, uma sugestão estrategicamente oca (resguardo do dedo indicador, para o não-senso). Decida-se: coisas que não querem dizer, coisas da suavidade do não-dizer, indizíveis. Dá-se então que o que difere o efeito desta flor de vidro de outros efeitos é que aqui ele já não se restringe à síntese de um sentimento (apenas ausência e presença ou qualquer outra tradução): cogita-se o que é geográfico, a materialidade mesma da flor, coisa efetiva, supostamente visível, que pode se revelar e ocupar um lugar no espaço físico: Às vezes, pensando ter divisado a flor de vidro no alto de uma árvore, comprimia Marialice nos braços. Ela assustava-se, olhava-o silenciosa, à espera de uma explicação. Contudo, ele guardava para si as razões do seu terror. Eis o buraco negro, a elipse - dir-seia, a crocodilagem -, o suplemento dispersivo que, para além dos pontos nevrálgicos, faz o conto transitar por algo muito diferente daquilo que a princípio ele parecia querer dizer (fá-lo também intransitar). Qualquer leitura do conto terá que lidar com o vinco: a flor de vidro não como um tropo vinculado à relação de Eronides com Marialice, mas como um possível objeto, sólido, acessível. Esta flor de vidro geograficamente avistável, diga-se, já não simboliza nenhuma memória (aquela reminiscência amarga) nem se investe automaticamente como um subproduto viabilizado pelo olhar da personagem (aquele "sinto, logo vejo"); agora domina, potente, autônoma, como uma já-presença que ainda não se revelou, virtualmente evidente, energeticamente pura e dura, presumida, como num mapeamento (no alto de uma árvore). $\mathrm{O}$ que Eronides pensa como hipótese se transveste fantasticamente: "pensar ter avistado" não é avistar, mas se pensando o que agora já pode se revelar em coordenada geodésica se eleva o que se pensa, potencialmente, ao que já é (ao que já está presente, como se percebe melhor adiante, no final do conto). Eronides pensa sobre a Coisa e se aterroriza, enquanto os olhos repousam sobre uma árvore (situação ótica e geográfica). Os olhos naturais, mediação por excelência, podem perfeitamente ultrapassar o limiar de sua representação 
especular, esta ilusão bastante convincente, não ter todo o objeto relacionado a fundamentos e a princípios que designam uma presença: agrimensores, não revelam a Coisa, mas espreitamna como possibilidade (situação puramente ótica e geográfica). Contudo, no momento da despedida, na plataforma da estação, a presença se revela, às escâncaras - isto, como se pode supor uma já-presença que depois já-se-revela: Quando o trem se pôs em movimento, a presença da flor de vidro revelou-se imediatamente. (sim, isto mesmo, "a presença" - uma já-presença que enfim se revela).

Contra qualquer insistência de dar senso-significado ao não-senso, indague-se, pois: e se a experiência de Eronides deve ser mantida onde está, em seu verniz imóvel, não como em um "símbolo flor", mas como um verniz-flor, verniz que é flor, como não-senso, nesse volume vago que ela é, pulsando em torno do seu enigma interminável, como flecha à imaginação que ricocheteia aqui, ali, ademais? Como apreensão instantânea de uma multiplicidade intensiva, a flor se tornou indigesta à funcionalização aparentemente operada pela intriga - neste instante, no que a própria máquina-conto propõe, pode ser decidida como não-senso. Uma gorda saúde de significados que embarrigam outros significados já não é possível: a história foge pelos lados, aí, transposta, sutilmente, deslocada para fora do lugar previsto, siderada: ela, que até então poderia estar operando certo movimento narrativo como teia de associações que simbolicamente não pressupunha vincos, deixa o leitor no umbral de uma imagem que está para além de qualquer ideia de "função contínua", “imagem-síntese", "imagem-ação" - ou, como gostava de dissertar Deleuze ao falar de cinema, especialmente do cinema de Godard, atola-se numa imagem-tempo indecomponível, que é pura intoxicação, fascinação, que não resulta mais simplesmente do movimento. ${ }^{62}$ Se até agora o que permitia alguma interpretação eram as semelhanças, este campo provável das combinações, neste momento as diferenças fazem da interpretação uma tarefa infinita e - por que não? - inútil; se as coisas se dispunham de modo razoavelmente homogêneo em terreno homogêneo, remetendo-se umas às outras, aparecem agora de modo diferenciado, geograficamente, figurais, segundo a dimensão de uma superfície. No movimento, a flor até então parecia

\footnotetext{
${ }^{62}$ Deleuze distingue dois tipos de imagens cinematográficas: imagens-movimento, caracterizando o cinema que ele chama de "clássico"; imagens-tempo, caracterizando o cinema "moderno", isto é, posterior à crise do cinema clássico, depois da Segunda Guerra. O que diferencia os dois tipos é sua relação com o tempo: no primeiro caso, tempo subordinado ao movimento; no segundo, movimento subordinado ao tempo. O cinema das imagensmovimento dá uma representação indireta do tempo, pelo movimento, representando o tempo em ação: as imagens agem e reagem umas sobre as outras (a ação é fundamental), construindo uma unidade orgânica, uma conexão empírica e cronológica. Já o cinema das imagens-tempo deixa de existir em função da ação: dá uma apresentação direta do tempo, uma apresentação do tempo puro, emancipado do movimento, o tempo como acontecimento, subordinando a ação, exigindo cada vez mais "pensamento". Cf. Gilles Deleuze, Cinema 1 - A imagem-movimento, São Paulo: Brasiliense, 1985 e Cinema 2 - A imagem-tempo, São Paulo: Brasiliense, 1990. Cf. também: Roberto Machado, “A imagem-tempo”, in Deleuze, a arte e a filosofia, Rio de Janeiro: Zahar, 2010.
} 
prever uma saída do enigma, feito correias, juntas, polias, conectores administráveis, todos numa só linha de montagem, tal qual fordismo (como se disse, a flor de vidro simbolizando isto ou aquilo, nisto), substituindo, assim, sempre, a ideia de máquina enigmática pela noção de conjunto funcional; como imagem-tempo, porém, ela já não propõe uma saída ao leitor, não há mais nada para ver por trás dela, nada a dizer sobre ela, que desliza obtusa, particularíssima, em provável relevo - cujo fundo é sempre fundo sem fundo, sem fundamento. Indizível e bela, ninguém sabe, ao fim, o que ela é: Eronides realmente guardou para si as razões do seu terror. ${ }^{63}$

Este é o elemento de indeterminação que com força fluida e caótica obscurece totalmente as associações até então produzidas. Houve um perpétuo combate (fração, sobras, pétalas, cacos) entre o que se sentia, o que se via e o que se propunha como objeto: reminiscências amargas, movimentos que se insinuaram pelos campos, fagulhas de trem, apito com nota angustiante, navalha e venda, cabelos que reapareceram, olhos que brilharam, aparências, corpo de vinte e dois, dezoito anos, flor azul, flor de vidro. Mas o leitor desconfia agora de que isto é puro estrebuchamento. É vinco: ao contrário de um sempre movimento, um curto-circuito - para que somente estados brutos corram atrás de outros (carrossel: dobra, desdobra, redobra). Passou-se do conto ao poema? Dá vontade de lembrar: Octavio Paz afirmava, embora numa perspectiva diferente, que num poema uma imagem expressa o indizível e explica a si mesma: somente ela diz o que quer dizer (isto é, significado e imagem são a mesma coisa): "as imagens são irredutíveis a qualquer explicação e interpretação". ${ }^{64}$ "A flor de vidro", nesse caso, seria uma daquelas narrativas perturbadoras que rompem a distinção entre prosa e poema (aliás, como pressupõe o próprio Paz, em $O$ arco e a Lira, a propósito de Aurélia, de Gérard de Nerval, e Os cantos de Maldoror, de Lautréamont) ${ }^{65}$, ou, sob as categorias "analogia" e "ironia" que Paz usa em Os filhos do barro, talvez uma narrativa do polo da ironia (onde estaria a estética do grotesco, o bizarro, o único), ironia que, conforme Paz, "não é uma palavra nem um discurso, mas o reverso da palavra, a nãocomunicação" ${ }^{66}$ Isto: uma espécie de invenção irredutível, uma pirotecnia que já não deve se fixar em significações. Não é viável interpretá-la se apoiando no senso comum nem fazê-la um êxito estético que fala de conhecidíssimas inquietações humanas (como se faz às vezes a

\footnotetext{
${ }^{63}$ Não à toa Antonio Candido relacionou alguns contos de Rubião com o Marienbad de Robbe-Grillet e Resnais. ${ }^{64}$ Octavio Paz, "A imagem”, in Signos em rotação, São Paulo: Perspectiva, 2009, p. 47-8. O modo como Paz pensa o "indizível" numa perspectiva diferente pode ser identificado em Octavio Paz, "A consagração do instante", in Signos em rotação, São Paulo: Perspectiva, 2009.

${ }^{65}$ Cf. Octavio Paz, O arco e a lira, Rio de Janeiro: Nova Fronteira, 1982.

${ }^{66}$ Octavio Paz, Os filhos do Barro, Rio de Janeiro: Nova Fronteira, 1984, p. 101.
} 
partir de Kafka). É preciso liberá-la, segui-la, sem domesticar as suas bifurcações, aceitá-la em seu engenho intransitivo, indizível, figural, especialmente sem pretensões de leituras totalizantes (estas, que, num texto, gostam de ver todos os dados sempre em movimento para depois parafusarem o Oiapoque no Chuí, quando não querendo colher uvas em espinheiros), renunciar à tentativa de descobrir os seus "verdadeiros significados" e ao programa tradicional de elucidar objetos. Para o crítico, cabe o não-dizer (verdadeiramente, o ideal seria ele nada dizer): imaginar. Marialice vai com o trem que desaparece nos trilhos paralelos, a presença da flor de vidro imediatamente se revela, os olhos se turvam, um galho lhe cega: esta, uma trivalência sentimento-olho-objeto bela e misteriosa, que finge dizer e diz, sem dizer totalmente. Está-se no não-senso, naquilo que não é verdadeiro nem falso: tal ilegibilidade, que é essencial para o seu vigor, para a sua relevância, não resulta simplesmente do que se conta, mas dessa alternância indecidível da imagem pura, que já não deve ser decidida, por exemplo, numa oposição ausência/presença, que não deve ser controlada e organizada por antagonismos ou compatibilidades - alternância, este modo como os processos ao mesmo tempo instam a uma escolha e impedem que esta escolha seja feita. Idolatra-se, assim, a dúvida, com prazer, com ligaduras tanto sorrateiras quanto obscuras, não simbólicas, vestígios de vestígios: pois não existe a última palavra nisso, não pode haver nisso a última palavra; de fato, não há palavra nisso, não deve haver palavra. Efeitos de verniz: é potente porque mais abstrato, é belo porque mais misterioso, capaz de escapar miudamente do leitor: como Marialice (quando percebe o terror de Eronides), o leitor ficará à espera de uma explicação (sim, sempre). 


\section{IV - DOBRA AGNÓSTICA}

Há, por exemplo, um sábio anônimo: ele vê algo e diz - é uma voz, uma voz de infernos e céus abertos, Hades e Canaãs, o que introduz o texto rubiano; voz que conforma e deforma a forma, pirueta, não elevada à condição de "significação das significações" (Ser, Ideia, Deus, Razão, Realidade). Posta nele, já não. Essencialmente, imagens - não discursos. Somente algum aparato interpretativo ulterior, no arbitrário que lhe será inerente, é que tentará tornálas significadas, encadeadas, relacionais. É de bom tom que sejam lidas tais como são: imagens - como "estrelas d'alva", "assembleia de gigantes", "dragões que zombam no mar", "lodo do fundo de grandes águas" etc. Para evocarem o solo figural no qual foram semeadas, pedem leituras que procedam apenas por experiências - em que se imagine, assim: são um inexpresso singular, medusais, dobradais, vernizais; imagens que são teofania - mas, sim, indizíveis, inefáveis, como são encontráveis em muitas teofanias bíblicas e semitismos (mas também, pode-se lembrar, em homerismos, greco-romanismos, gongorismos, paganismos, liturgias várias). Tal petição de leitura visa sublinhar, talvez, como a sua incomunicação nos contos será um privilégio: à margem das relações significativas, como proclamações enigmáticas, pressupondo uma ruptura radical com as formas perceptivas do aqui-presente da leitura e com as tentativas universalizantes ou catolicizantes da explicação laboratorial apenas figurando, aquém, além. Há sábios, profetas, visionários, apóstolos: o leitor de Rubião deve engolir de antemão o que esses anônimos veem e dizem (sapiências, profetismos, coisas apocalípticas, apostólicas), engolir sem colocar necessariamente o que é visto e dito na escala do "discernível": apenas concordar imageticamente com o que se propõe, deslizar, boiar e boiar novamente, na superfície, setenta vezes sete, não mergulhar, não teologizar: $E$ se levantará pela tarde sobre ti uma luz como a do meio dia; e quando te julgares consumido, nascerás como a estrela d'alva (em "O pirotécnico Zacarias"); O homem que se extraviar do caminho da doutrina terá por morada a assembleia dos gigantes (em "Bárbara"); Este mar amplo, largo de braços, nele sulcam as naus, o dragão que formaste para zombar no mar (em “Ofélia, meu cachimbo e o mar"); Tu abriste caminho aos teus cavalos no mar, através do lodo que se acha no fundo das grandes águas (em "O lodo"); E toda a ilha fugiu, e os montes não foram encontrados (em "Bruma"); Porque se a trombeta der um som confuso, quem se preparará para a batalha? (em “A armadilha”). Para triunfar, essa leitura deve, como em toda lógica alógica, imaginar. Mas se há ainda aqui um inferno de dúvidas ou um céu de certezas, tome-se o caso como pergunta, em senso-significado: a voz epigráfica o que diz? 
De modo geral, uma epígrafe (escrita sobre ou escrita em) visa condensar significados, como as gravações de palavras numa ara votiva ou tumular, podendo se relacionar semanticamente com a ideia de sinopse, designação ou preceito. Mas, antecedendo um texto literário, pode ser simples adereço ou conformar, a partir de uma citação relevante, uma legitimação cultural necessária. Também pode funcionar duplamente: como referência intertextual, que remete o texto literário a um regime discursivo determinado - no caso de Rubião, a Bíblia - e como protocolo de leitura, um índice programático para o leitor, indicando-lhe que a narrativa desenvolve a citação, é interpretável pela citação ou hospeda a citação. Uma epígrafe pouco ajustada às possibilidades narradas, mesmo às possibilidades mais amplas e flexíveis, pode explicitar fratura, violação ou disritmia entre discursos, destituídos de relações evidentes de causa e efeito, simetria, contrato: pode estar associada a uma estratégica "falta de função", que funciona como uma interrogação perene, frustrando a correlação com a narrativa, apartada propriamente da afirmação, da negação ou do comentário. Nos contos de Rubião, o leitor talvez não conceda importância à presença da epígrafe bíblica, percebendo-a apenas como um índice de erudição capenga, impropriamente oriundo do "universo religioso", avulso, não fluente; ou talvez se deixe perturbar pela voz epigráfica na narrativa, hesitando entre similitude e descontinuidade. De qualquer forma, ficará num interlúdio de indagações, pois não é o caso de apenas alguns contos apresentarem uma epígrafe. Abarcando todos os contos, o colarinho talvez corresponda a um projeto artístico fundamental. Já no primeiro livro, O ex-mágico (1947), Rubião tornara a ideia um componente de sua obra, inserindo uma arquiepígrafe ( $\mathrm{Gn} 9.14$ ) para todo o conjunto de quinze contos - este, dividido em cinco partes de três contos, cada parte também encimada por uma epígrafe bíblica. A realização sugeriu a Schwartz uma leitura horizontal das epígrafes, relacionando-as umas com as outras, para propor, em senso-significado, que neste livro elas constituem um universo narrativo completo, assim como um feixe gerador das epígrafes subsequentes, numa espécie de constelação epigráfica em que os significados-base se preservam e se disseminam pelo resto da obra. ${ }^{67}$ Nos livros posteriores, então, todos os contos, inéditos ou reescritos, receberam epígrafes individuais, reforçando a ideia da relação das epígrafes com os contos correspondentes, cujo efeito sibilino, sabe-se, tornou-se uma das principais marcas rubianas.

\footnotetext{
${ }^{67}$ Cf. Jorge Schwartz, "As epígrafes como programa textual”, in Murilo Rubião: a poética do uroboro, São Paulo: Ática, 1981.
} 
Mas não é possível entender tal relação como processos computáveis ou facilmente discerníveis: um conto enquanto obra é substancialmente um objeto definido, mas enquanto texto não possui fronteiras perenes nem se fecha num significado solene. Talvez seja caso para não se desconsiderar, por enquanto, várias possibilidades: ornamento, busca de autoridade, referência, espelho temático, síntese, protocolo, efeito-fratura, interrogação. Ainda assim, pergunte-se: ficaria a cargo do leitor uma atribuição de pertinência ou a epígrafe representaria em si um apontamento monolítico, inconfundível? Qual seria o problema epigráfico? Embora sendo apenas "pedaços", versículos, as epigrafes poderiam ser entendidas como unidades constitutivas de uma complexidade incessante, isto é, como argumentos em expansão? Poderiam gozar de um estatuto semântico especial, identificável somente por certa unidade sintática ou oracional, devendo quando muito funcionar como sinédoques do texto original, no jogo da parte pelo todo? Schwartz, ao propor que as epígrafes de Rubião "se desdobram numa relação dicotômica epígrafe/conto (relação intertextual), e epígrafe/epígrafe (relação intratextual)", opta pela ideia de que "constituem um paradoxo provocado pela tensão do seu próprio status, autônomo e ao mesmo tempo dependente, em relação ao texto-base (o conto)". ${ }^{68}$ Ainda assim, indague-se: seria então conveniente lê-las somente num sentido gramatical, desconectando-as completamente de sua fonte, o endereço primitivo? Decerto, ao serem extraídas do texto de origem, perderam a funcionalidade original, como todo fragmento peregrino, e se refuncionalizaram no novo ambiente, transitando agora entre a carga semântica do texto do qual vieram e a carga semântica proveniente de suas possíveis relações no novo contexto. Porém, permanece ainda a dúvida a respeito desta nova funcionalidade que no limiar da intertextualidade e da interdiscursividade não pode escusar o próprio berço nem o novo cômodo. Permanece também um escrúpulo quanto à voz epigráfica e ao epigrafador: quem fala e quem epigrafa? Obviamente, estas (e outras) perguntas envolvem vários tipos de dificuldades. Eis outro problema em Rubião.

Gérard Genette, que a partir da noção de dialogismo (Bakhtin) e de intertextualidade (Kristeva) propõe transtextualidade como um termo mais amplo, define a epígrafe sob a categoria paratexte, uma “'zona indecisa' entre o dentro e o fora, sem limite rigoroso, nem para o interior (o texto) nem para o exterior (o discurso do mundo sobre o texto)". ${ }^{69}$ Os paratextos seriam "escritos" complementares, secundários ou subsidiários, inseridos ao lado, dentro ou fora do espaço do texto principal - por exemplo, apresentação editorial, títulos,

\footnotetext{
68 Jorge Schwartz, "Do fantástico como máscara", in Murilo Rubião, O convidado: contos, São Paulo: Ática, 1983, p. 6.

${ }^{69}$ Gérard Genette, Paratextos Editoriais, Cotia: Ateliê Editorial, 2009, p. 10.
} 
dedicatórias, prefácios, epígrafes e notas -, cujo aspecto funcional não deveria ser desprezado: regulador das leituras, função privilegiada na dimensão pragmática. As obras literárias nunca teriam se apresentado como um texto nu, já que sempre cercadas deste aparato, muitas vezes "visível demais" para ser percebido. A ideia é retrabalhada por alguns pensadores: Umberto Eco, por exemplo, utiliza o termo paratexto para discorrer sobre a intrincada rede que se estabelece entre autor, narrador e personagem em $O$ relato de Arthur Gordon Pym, de Edgar Allan Poe: o "Prefácio" e a "Nota ao leitor" seriam paratextos que visariam confundir o leitor sobre a verdadeira identidade do autor do relato. ${ }^{70}$ Observe-se, a propósito, tentando um diálogo com Genette e Eco, que noutras vezes o aparato se apresentou tanto visível pela "edição" do próprio autor quanto utilizado evidentemente como metáfora crítica: lembre-se, por exemplo, da tentativa de Oswald de Andrade em Serafim Ponte Grande (1933) de constituir uma desarticulação da forma romanesca convencional já a partir do paratexto: no lugar previsto para as informações iniciais, onde comumente seria colocada uma lista de obras sob o título "Obras do autor", Oswald preferiu o título "Obras renegadas", incluindo na lista o próprio livro que o leitor está para ler; no lugar de copyright, que se relacionaria aos direitos autorais ou de propriedade literária, encontra-se a frase imprevista "Direito de ser traduzido, reproduzido e deformado em todas as línguas"; nas páginas finais, uma "Errata", deslocada da posição e do significado tradicionais, funciona na verdade como um capítulo autônomo; adiante, o que corresponderia a uma "última página" - onde seria natural se colocar informações precisas sobre a data e o lugar da impressão, por exemplo - recebe um tratamento pouco usual: "Este livro foi escrito de 1929 (era de Wall-Street e Cristo) para trás".71 Obviamente, esses paratextos oswaldianos, explícitos e deliberadamente marcados, além de apontarem para a natureza inusitada que se quer para a criação, pretendem autorizar tipos de leitura que, tendo como desautomatizada a materialidade do objeto, possam ser encaminhados também de forma desautomatizada. Pode-se afirmar, é claro, que não são paratextos convencionais: no artifício do livro, desdobram-se como elementos pseudo-paratextuais, hilários, construídos, talvez, ou é claro, sob o riso escarninho de Oswald. Têm uma intenção estética que, na materialidade moderna de sua realização, excede os percursos sistematizáveis, articulando em si e a partir de si vicissitudes artísticas e críticas amplamente conectadas à natureza que se quer para a obra.

\footnotetext{
${ }^{70}$ Cf. Umberto Eco, Seis passeios pelos bosques da ficção, São Paulo: Companhia das Letras, 2009, p. 24-26.

${ }^{71}$ Cf. comentários de Haroldo de Campos, "Serafim: um grande não-livro", in Oswald de Andrade, Serafim Ponte Grande, São Paulo: Globo, 1996.
} 
Em Rubião, o uso dos versos bíblicos, destacados na primeira página de cada conto, não pode remeter a outra coisa senão a algo que também "transcria", de certa forma, em sua modernidade, deliberações editoriais já conhecidas. Sobre o uso moderno das epígrafes, Genette observa que, no século XVIII, por exemplo, fora da La Nouvelle Heloise (1761), de Jean-Jacques Rousseau, elas quase não aparecem nos grandes romances - exceto em alguns casos, como na abertura de Tom Jones (1749), de Henry Fielding, e de Tristam Shandy (17601767), de Laurence Sterne -, mas que, ao mesmo tempo, são introduzidas maciçamente no roman noir, o chamado romance "gótico" ou "frenético", e na prosa narrativa de Walter Scott. Registre-se que, embora The Castle of Otranto (1764), de Horace Walpole, ainda não apresentasse epígrafes, elas apareceram, uma em cada capítulo, em The Misteries of Udolpho (1794), de Ann Radcliffe, em The Monk (1795), de Matthew Gregory Lewis, e em Melmoth (1820), de Charles Robert Maturin. Na obra de Walter Scott - autor que depois será fundamental para Victor Hugo, por exemplo - as epígrafes frequentemente aparecem. Esta moda inglesa da epígrafe romanesca teria passado para a França no início do século XIX, via Charles Nodier e outros, quando a literatura francesa descobriu e difundiu, especialmente por Nodier, o roman noir do pré-romantismo inglês: Walpole, Radcliffe, Lewis, Maturin. Considere-se aqui, como parêntese, que é exatamente esta linha do "frenético" que Victor Hugo seguirá em seu primeiro romance, Han D'Islande (1823), onde a presença de Scott é marcada: aparecem como epígrafes uma citação de Ivanhoé (1819), no capítulo XXXIX, e um fragmento do poema Harold l'Intrépide, no capítulo XLV. A linha seguida por Hugo seria uma das formas da narrativa fantástica que emanou da literatura romântica de evasão e prolongou a tendência do pré-romantismo inglês, conhecida como roman noir ou romance gótico. No Han D'Islande, a temática, a caracterização do espaço e a caracterização da personagem que dá nome ao livro confirmariam esta correlação, bem como algumas das epígrafes que abrem os capítulos e dialogam diretamente com a tradição. ${ }^{72}$ Ademais, voltando a Genette, agora sobre o mesmo Han D'Islande, todos os 51 capítulos possuem pelo menos uma epígrafe, possivelmente oriundas de autores estrategicamente escolhidos. Na França, também Stendhal teria herdado de Scott o hábito das epígrafes; já Balzac, que nas obras de juventude e nas narrativas históricas de tipo scottiano tinha usado muitas epígrafes, teria repudiado o uso delas depois, à medida que abandonava, nas palavras de Genette, "o propósito da narrativa histórica, fantástica ou 'filosófica', em proveito do grande romance". ${ }^{73}$

\footnotetext{
${ }^{72}$ Cf. Ana Luiza Silva Camarani, "Intertextualidade e frenético em Han d'Islande”, in Lettres Françaises, São Paulo, FCL/UNESP/Araraquara, v. 5, p. 35-47, 2003.

${ }^{73}$ Gérard Genette, op. cit., p. 135.
} 
Das mais arcaicas lápides, que remontam aproximadamente ao século VII a.C., construídas por frases sintéticas, graves e ordinárias, aos textos literários dos séculos XIX e $\mathrm{XX}$, onde elas sobejam sobre, sob ou em poemas, contos e romances, coloca-se em pauta a indagação a respeito de sua função. Se no caso de Oswald há uma deliberação clara que por meio do livro problematiza a ideia "livro", o que dizer dos casos em que a função dos paratextos não é evidente? Em qualquer texto, se houvesse uniformidade de uso, decerto $o$ lugar da epígrafe acarretaria uma função exata: com relação ao leitor, a epígrafe no início anteciparia algum aspecto importante do texto, como possivelmente faz a epígrafe oriunda de Pierre-Jean De Béranger no conto “A queda da casa de Usher” (1839), de Edgar Allan Poe; no meio ou ao lado, caminharia com o texto, exigindo uma dupla leitura, essencialmente importante para o entendimento do texto principal; no fim, numa espécie de "palavra final", poderia ter uma significação conclusiva; no início e no fim, poderia indicar um significado reiterativo que apontaria para a necessidade de se repetir a leitura e descobrir outros significados, como o que parece ser possível deduzir pelas duas epígrafes de Schopenhauer em Tutaméia (1967), de Guimarães Rosa ${ }^{74}$; em cinta, muito exposta, naquela espécie de "faixa" no terço inferior do livro - como apareceu, por exemplo, a epígrafe retirada de Sartre em Politique de la prose (1982), de Denis Hollier -, assumiria uma função estratégica que, como presença monumental, dificilmente poderia implicar outra coisa senão a aderência total do texto principal ao seu apontamento. Sendo variáveis a posição e a ocasião da epígrafe, declináveis seriam as funções; mas o leitor ainda teria uma direção razoavelmente sistemática para discernir a sua utilidade no arranjo. No caso de Rubião, em que as epígrafes coroam os contos, bastaria prever certa relação automática entre epígrafe e narrativa - talvez, a epígrafe funcionando como um "comentário", da mesma forma que, como lembra Genette, uma citação de Píndaro abre "O cemitério marinho" (1922), de Paul Valéry, e uma de Céline, A náusea (1938), de Jean-Paul Sartre -, uma relação cuja pertinência semântica não poderia exceder a ordem do acessível, posto que vulnerável à primeira leitura. Aqui, no entanto, a espécie do texto epigrafado, espécie bíblica, investiria certa carga problemática: mesmo que as exigências básicas fossem a de não confundir os textos do Livro com os textos e discursos que são feitos sobre o Livro e a de não confundir o uso literário do texto bíblico com o uso religioso do texto bíblico, subsistiria a hipótese da permanência do ideário religioso na invenção, na qual se poderia sugerir que o conto deve ser lido como exempla, isto é, como um caso exemplar da verdade contida na epígrafe (da mesma forma que se encontra na tradição

\footnotetext{
${ }^{74}$ Cf. Gilberto Mendonça Teles, “O pequeno 'sertão` de Tutaméia”, in Navegações, Porto Alegre, PUC-RS, v. 2 , p. 109-115, 2009.
} 
patrística e medieval). Neste caso, dever-se-ia identificar se a epígrafe vem do Antigo ou do Novo Testamento, o que exigiria distinguir, por exemplo, os modos com que os dois testamentos se referem a Deus e ao ser humano. Poderia se tornar interessante considerar, nisso, que a maior parte das trinta e três epígrafes vem da poesia veterotestamentária: vinte e sete epígrafes do Antigo Testamento, com a predominância de seis epígrafes retiradas de Jó, que parece ter sido um dos livros preferenciais do autor, e seis epígrafes do Novo Testamento, das quais três retiradas do Apocalipse. ${ }^{75}$ Se as preferências bíblicas de Rubião têm base num projeto literário, poderia se tornar relevante, neste caso, consignar a predominância da escolha por "passagens poéticas", cujas formulações mais significativas, não raramente se diz, parecem ser as que são encontradas exatamente em alguns livros do Antigo Testamento e no Apocalipse. ${ }^{76}$ Sob o fragmento cuja procedência é o Livro, dir-se-ia, nesta hipótese, que há algo a ampliar, que o tênue se obriga ao grande, não é inexato nem efêmero: fragmento que deve levar ao não-fragmento, "detalhe" que desabrocha o geral.

Todavia, advirta-se que, além de serem absolutamente plausíveis gratuidades em Rubião, quase sempre não é patente a relação da epígrafe com o conto correspondente. Restrita à correlação temática, por exemplo, frustra-se a leitura impregnada do método interpretativo tradicional comumente aplicado a inscrições, aquele que tateia um significado cristalino a partir do lugar da citação, aquele que dela requer límpida antecipação, resumo ou comentário. Certas epígrafes parecem reclamar autonomia, feito enunciações independentes. Pense-se: que relação transparente seria possível assimilar entre o verso retirado da fala de Bildade $^{77}$, amigo de Jó, e a história de Pererico, em "A fila"? Em "Alfredo", que pertença unívoca haveria entre a epígrafe, que é uma oração litúrgica, sálmica ${ }^{78}$, e as instâncias animalescas, lobisominais, dromedariais, porcais, que ali aparecem? De fato, as epígrafes cabem em qualquer história - se trocadas, emprestadas, comercializadas. Uma leitura que, com negligência, conectasse simples expressões ou palavras da epígrafe com as do conto, ou que se limitasse à questão da "mensagem" ou ao "espírito da coisa", procurando desvendar possíveis alianças entre uma comunicação epigráfica e uma comunicação narrativa, poderia incidir na soleira, no anteparo literário, particularizando quase sempre uma "descoberta" banal e restrita, satisfazendo-se apenas na semente, num raso "isto implica aquilo", orientando-se

\footnotetext{
75 O conto "Memórias do contabilista Pedro Inácio" é o único que recebe duas epígrafes: um versículo (Jr 12.5) e uma frase retirada de Memórias Póstumas de Brás Cubas.

${ }^{76}$ Cf. Robert Alter, "As características da antiga poesia hebraica", in Robert Alter e Frank Kermode (orgs.), Guia Literário da Bíblia, São Paulo: Editora UNESP, 1997.

${ }^{77}$ Jó 8.10: E eles te instruirão, te falarão, e do seu coração tirarão palavras.

${ }^{78}$ S1 85.1: Inclina, Senhor, o teu ouvido, e ouve-me; porque eu sou desvalido e pobre.
} 
pelas arestas, esbarrando, enfim, na polissemia das palavras, nas armadilhas da linguagem: restaria somente o esforço despendido nos frágeis laços das vãs deduções. As tentativas realizadas com este propósito geralmente engatam as epígrafes às narrativas contorcendo distintos painéis semânticos, deliberadamente, entrando à força, até a monopolização de todos os significados, transitando da indistinção entre texto bíblico e discursos históricos sobre o texto bíblico aos mais reconhecíveis anacronismos. ${ }^{79}$ Daí que para Hermenegildo José Bastos, por exemplo, as epígrafes em Rubião "não têm uma função primordial nos contos, ou, se têm, é para desdizerem e, assim, desdizerem a sua condição primordial. São marcas da transgressão. Aí estão para negar a si próprias. Rescritas, dão-se como visões alucinatórias, como texto fantasma". ${ }^{80}$ De fato, algumas parecem reclamar independência, como que regidas por leis próprias (ou no mínimo que pertencem mesmo a outro discurso, no qual permanecem; que intentam um “de passagem”, obtusas, escorregadias, não obstante o autor as tenha querido alçadas sobre um Xixiu, um Jadon, um Colebra, um Manfredo).

Sob o "luxo da epígrafe" 81 , poderia o leitor, no entanto, entendê-la como um ornamento, adereço, ou suspeitá-la como acaso, deixando-a tanto exterior quanto seria aparentemente interior ao texto literário. Em Sagarana de Guimarães Rosa, por exemplo, Nelly Novaes Coelho prefere entender que os versinhos populares à guisa de epígrafes não são funcionais, não estão ligados a algo essencial da narrativa (as "cantigas-epígrafes" de Sagarana seriam “gratuitas"): "Valem por si, como 'palavra poética` que são, para comunicar ao leitor a beleza, a alegria ou a emoção dos gestos não-pragmáticos e que visam espontaneamente à doação de si próprios". ${ }^{82}$ Sabe-se que o grande consumo de epígrafes, em alguns escritores e em certos momentos, poderia ser visto, é claro, como que reduzido ao "efeito-epígrafe", isto é, à simples presença da epígrafe - desde que oriunda de "autoridades", como veículo de integração da nova obra numa tradição cultural de prestígio, como sinal de cultura e intelectualidade (o que não parece ser o caso em Rubião). Neste sentido volátil, poder-se-ia entender qualquer epígrafe como que desconectada do texto literário propriamente dito, isolada, cuja funcionalidade se abreviaria numa função de consumo, ou, precisamente - se trazendo uns bocados de palavras de um Mallarmé, um Lautréamont, um Blanchot, um Proust ou de outro

\footnotetext{
${ }^{79}$ Porém, uma tentativa bem intencionada de leitura epigráfica em Rubião pode ser encontrada em Audemaro Goulart Taranto, "A leitura epigráfica", in O conto fantástico de Murilo Rubião, Belo Horizonte: Lê, 1995.

${ }^{80}$ Hermenegildo José Bastos, Literatura e colonialismo: rotas de navegação e comércio no fantástico de Murilo Rubião, Brasília: Editora da UNB, Plano Editora, 2001, p. 17.

${ }^{81}$ A expressão é de Fábio Lucas, ao tratar da busca autoral pela epígrafe como uma procura por "argumento de autoridade". Cf. Fábio Lucas, "O mundo das inscrições", in Fronteiras Imaginárias, Rio de Janeiro: Cátedra, 1971 , p. 15.

${ }^{82}$ Nelly Novaes Coelho, "Guimarães Rosa e a tendência regionalista", in Affonso Ávila (org.), O Modernismo, São Paulo: Perspectiva, 1975, p. 207.
} 
grande nome -, numa tentativa de sorver algum crédito. O leitor de Rubião deveria então não prezar o eco, o rumor e as concernências julgadas possíveis: calcificados seriam os "espinhos e urtigas" junto ao moto perpétuo do enterrar e desenterrar Petúnias; mergulhada no silêncio e no valor reles seria a "assembleia dos gigantes" em "Bárbara"; do Botão-de-Rosa, apartado seria o "aroma de mirra, de aloés e cássia". Entretanto, o que dizer das epígrafes que parecem se ajustar perfeitamente à narrativa? Desnudas de intenções indecifráveis, têm-se como voz ativa do que lhes segue. Veja-se em "Aglaia" a ideia da multiplicação de "trabalhos e partos" afirmada explicitamente na epígrafe retirada do Gênesis ${ }^{83}$ - como uma senda a ser percorrida, um há-de-ser - e a sua efetivação, que não é comprovação literal da epígrafe, mas um já-é, que se dá na fantasia, no parir desmedido, na ideia de partos numericamente elevados que caracteriza o relato. É de Schwartz a ideia de que na última fase de Rubião, que corresponderia, neste ponto, basicamente à coletânea $O$ convidado (1974), as epígrafes teriam um "tom profético", um "há-de-ser", revelando todas um momento a ser alcançado ou um caminho a ser trilhado. ${ }^{84}$ Veja-se também em "Teleco, o coelhinho" que o verso bíblico ${ }^{85}$, afirmando uma incompreensão sobre o "caminho do homem na sua mocidade", pode estar relacionado à instabilidade existencial da personagem e às suas metamorfoses, insólitos movimentos de mudança (coelho, girafa, leão, tigre), que carecem de um agente propulsor definido, assim como de convergência: resumem-se a um "simples desejo de agradar ao próximo”. Mas também há epígrafes que parecem apenas tocar o título do conto, repetindo uma palavra, sem necessariamente adiantarem-se em assunto: epígrafes de "O lodo" 86 , " $\mathrm{O}$ edifício" ${ }^{\prime 87}$ e "Os dragões”, conjugar, em termos de senso-significado, epígrafes e narrativas) que a aparente contaminação vocabular não facilita a visualização de uma mínima interdependência entre título, epígrafe e conto: reduz-se à repetência. Uma interdependência, se cogitada assim, através de uma simples repetição de palavra, tornar-se-ia tão movediça como seria movediça uma interpretação que pretendesse estabelecer correspondências apenas no palco dos vocábulos. De fato, em algum momento seria necessário lidar com o problema de que, stricto

\footnotetext{
${ }^{83} \mathrm{Gn}$ 3.16: Eu multiplicarei os teus trabalhos e os teus partos.

${ }^{84}$ Cf. Jorge Schwartz, "Do fantástico como máscara", in Murilo Rubião, O convidado: contos. São Paulo: Ática, 1983, p. 7-8.

${ }^{85}$ Pv 30.18,19: Três coisas me são dificeis de entender, e uma quarta eu a ignoro completamente: o caminho da águia no ar, o caminho da cobra sobre a pedra, o caminho da nau no meio do mar, e o caminho do homem na sua mocidade.

${ }^{86} \mathrm{Hb}$ 3.15: Tu abriste caminho aos teus cavalos no mar, através de lodo que se acha no fundo das grandes águas.

${ }^{87} \mathrm{Mq}$ 7.11: Chegará o dia em que os teus pardieiros se transformarão em edifícios; naquele dia ficarás fora da lei.

${ }^{88}$ Jó 30.29: Fui irmão de dragões e companheiro de avestruzes.
} 
sensu, os possíveis significados de "lodo", "edifícios" ou "dragões" nos versos hebraicos dificilmente poderiam conduzir o leitor aos possíveis significados de "lodo", "edifício" ou “dragões" nos contos rubianos. Pode-se pensar novamente: este paratexto, então, quer-se livre; talvez, queira-se tão livre como deve ser livre a liberdade do leitor, desobrigado de leválo em conta: um versículo de Mateus em “A casa do girassol vermelho”, um verso dos Salmos em "Ofélia, meu cachimbo e o mar", um provérbio em "Elisa" - e nada mais. Aqui, ou se entenderia que Rubião teria buscado nas epígrafes o mote para simplesmente embaralhar a sua criação, ou provocar dissonâncias, ou falsear instâncias inapreensíveis, ou como recurso para dar voz a fantasmas do sujeito (vertente da psicanálise) ${ }^{89}$, ou se entenderia a presença das epígrafes como meros "enfeites”. Contudo, tal caráter irregular não impediria que este leitor livre se deparasse e se perturbasse, conto a conto, com as epígrafes livres. Perturbando-o, pareceriam atreladas ao conto: em algum momento seria necessário lidar com o problema de que, lato sensu, algo poderia pertencer ou se relacionar com as narrativas. Em cada caso, a perturbação adquiriria as mesmas feições intransigentes - assim: se uma solução convém, se é bem o caso, se alguma coisa é viável, se há o que se perturbar; no limite, toda a intransitividade como possibilidade e fantasma, toda a falta de jurisprudência do leitor. De fato, como em Scott, Nodier, Hugo e Stendhal, apreciadores de epígrafes decididamente enigmáticas, estranhas ou misteriosas, em Rubião quase sempre as epígrafes colocam à prova a capacidade de decidi-las em senso-significado.

O que é o que é? Não nuclearmente, ou seja, sem alguma noção de nuclearidade na epígrafe, pensa-se apenas em senso-significado: que as epígrafes criam instâncias de significação com os contos (como é possível pensar, assim, diretamente, pela epígrafe retirada do livro de Jó em "O pirotécnico Zacarias" "90: primeiro, que a expressão epigráfica "quando te julgares consumido" reverbera a condição paradoxal do vivo-morto, isto é, a condição do morto que não foi totalmente consumido, que morreu e não morreu: Em verdade morri, o que vem ao encontro da versão dos que creem na minha morte. Por outro lado, também não estou morto, pois faço tudo o que antes fazia e, devo dizer, com mais agrado do que anteriormente.; segundo, que as expressões epigráficas "uma luz como a do meio-dia" e "nascerás como a estrela d'alva" depõem o horizonte utópico no qual o narrador-protagonista pensa relativamente por uma disposição cromática: [...] e o branco já se aproxima da terra para exclusiva ternura dos meus olhos.). O problema

\footnotetext{
${ }^{89}$ Cf., como exemplo, Márcia Marques de Morais, "Fantasmas (in)tangíveis nos contos de Murilo Rubião", in Revista Literatura e Sociedade, São Paulo, FFLCH/USP, v.10, p. 88-98, 2007/2008.

90 Jó 11.17: E se levantará pela tarde sobre ti uma luz como a do meio dia; e quando te julgares consumido, nascerás como a estrela d'alva.
} 
deste regime interpretante é que por vezes ele sonha visceralmente o fim do jogo, sonha os finais felizes em que todas as coisas se conectam, pensa em termos de "origem", "função", "lugar", "relação", "exempla", "profundidade”, obcecado; mas o jogo é (ainda em sensosignificado) o passar, o atravessar, o articular, o pôr em movimento, o esburacado. Não se pode falar que ele exprime uma verdade, nem mesmo que ele tem uma verdade: as tentativas de pensar Rubião por meio das epígrafes encontram sempre um plural de mil faces que não permite o frear da mobilidade: turbilhão que se nutre cada vez mais de turbilhões, proposições que se nutrem de proposições. As epígrafes não se dão aos percursos retilíneos, mas aos de curvatura, onde se evita o ângulo reto: têm um imenso grau de fluidez. Seu âmbito de significação é tanto móvel (como é possível pensar, de outra forma, pela mesma epígrafe de “O pirotécnico Zacarias”, que as expressões epigráficas, resignificadas agora com o humor que é próprio do conto, respondem às impropriedades das percepções metaforizadas, tanto às impropriedades ficcionais quanto às impropriedades epigráficas: na epígrafe, o nascer como a estrela d'alva; no pirotécnico, o re-nascer morto) quanto é um âmbito de significação vulnerável - o que permite dizer: todos os colarinhos rubianos facilmente se encaixariam em qualquer história, em qualquer obra literária, em qualquer invenção - sem pudores, com liberdade e libertinagem, qualquer um em qualquer uma, para inúmeras interpretações (como é possível pensar, assim, travestidamente, ainda pela epígrafe de "O pirotécnico Zacarias", uma camoniada aqui, uma robinsonada lá ou uma rosianiada qualquer de “terceira margem”). Em Rubião ou em outros, jogo sem fim.

Mas, conforme se aponta aqui o não-senso a partir da ideia de imagem pura (a Coisa que não deve ser substituída por outras coisas), talvez já não baste dizer que o jogo realmente não tem fim: ele não está só no corporal que é infinito e múltiplo como forma esponjosa, porosa e cavernosa, mas também no incorporal sem janelas para fora, sem portas, sem frestas: o acontecimento em que nada vem de fora ou vai para fora, o deixado como tal, o fluxo visto pragmaticamente como autônomo, o $x$ que só é $x$, o vazio, o simulacro não submetido às formas do inteligível, aquilo que exige certo não-senso crítico quando tomado por intangível. Enquanto certo texto pirotécnico ou certo arranjo pirotécnico num texto moderno se caracteriza por uma abertura, sempre potencializando significados, ao máximo grau, encontrase também cada vez mais irredutivelmente fechado numa zona de invisibilidade que o faz diferir e se afastar da discursividade interpretante, fechado numa zona que não se deve significar - talvez, apenas "imaginar" (não à toa o próprio âmbito do pensamento tem se constituído em alguns pensadores como uma efetiva escrita poético-teórica, inventiva e 
também impregnada da inventividade do artístico, para justamente transitar nesses horizontes de pensamento, para justamente poder "falar melhor" ou simplesmente "falar" de certas modalidades de pensamento potencializadas pelos objetos, para justamente tornar possível alguma aproximação ao poético indizível, como um novo tipo de "discursividade", sem mais se obstruir em fronteiras ou paredes que tradicionalmente se colocariam entre abstração e concreção, imagem e conceito, particular e geral, literatura e filosofia; sim, a linguagem fria, cinzenta e tecnicista há tempos se tornou de certa forma inviável ${ }^{91}$ ). Assim, se a primeira experiência nas epígrafes for a da interpretação relacional ou a indiferença - aquela, a de não cogitar que o fragmento se cale, não designe e passe ao largo do senso-significado; ou esta, o desprendimento pelo não literário (uma epígrafe é somente editorialismo, sem maiores afetações, sem maior importância) -, a segunda experiência nelas pode ser a das imagens imaginadas no porão escuro, fantasiadas sob a penúria da vela (imaginação que já não é interpretação, mas apenas um indefinível sopro sigético: o outro sendo visto essencialmente enquanto outro, sem relações demonstráveis, laboratoriais). Daí que seja possível dizer que as epígrafes bíblicas em Rubião não funcionam como imagens-movimento, mas como imagenstempo, puras, desconectadas, intransitivas: elas podem ser decididas como um não-significado (como é possível pensar, assim, na epígrafe de "O pirotécnico Zacarias”, seu caráter indizível de imagem bruta). Se têm um corporal de fluidez, têm também um enorme incorporal de dureza: um regime que não se deixar operar num "o que é x": efetivamente, lógica alógica. Quedam-se figurais, incomunicáveis, seja em contos em que pareça haver algum descompasso de significados entre a epígrafe e a narrativa (como em "Alfredo", "A noiva da casa azul" ou "Epidólia"), seja em contos em que pareça haver alguma sintonia de significados entre a epígrafe e a narrativa (como em "Aglaia” ou "Teleco, o coelhinho"). Ao mesmo tempo em que se pode pensar que a indecidibilidade é, em senso-significado, nos contos, um valor afirmativo, uma forma de afirmar a indecidibilidade do que será narrado (isto é, afirmar a sua mobilidade significativa), é possível pensar que a pirotecnia epigráfica é um não-senso; dela, agora, já será importante dizer: precisamente porque não significando, não-sendo; precisamente porque não-sendo, tornando-se irredutível, contentando-se em sua extensão plana. Pensa-se, pois, nisso, que o que deve haver é o que é de superfície: vozes epigráficas que já não admitem mergulhadores ou exploradores de profundezas significativas; vozes que são uma contraciência, um impermeável que finge ser permeável, um agnóstico que finge ser

\footnotetext{
${ }^{91}$ Cf., nesse sentido, Alberto Pucheu, "Pelo colorido, para além do cinzento (quase um manifesto)", in Pelo colorido, para além do cinzento, Rio de Janeiro: Beco do Azougue, 2007 e Alberto Pucheu, "Poesia e filosofia", in Giorgio Agamben: poesia, filosofia e crítica, Rio de Janeiro: Beco do Azougue, 2010.
} 
gnóstico. No pescoço dos contos, os sábios, os profetas, os visionários e os apóstolos já não trazem mensagens nem clichês: têm mãos anônimas. Não é muito se lambuzar novamente em Lyotard: há outro espaço, espaço figural. No jogo que já não é simples jogo de significados, pode-se pensar que o que não é discursivo não se dá ao regime discursivo, que é possível entende-las a partir de outra imagem do pensamento, amparando-se num filosofia de fantasma. Dobrar-se, aqui, é diminuir-se, reduzir-se, fechar-se, emaranhar-se, encerrar-se, nuclearizar-se. A brutalidade, a pureza, a dureza ou a atomicidade da epígrafe permite agora uma intempérie de modos que já não a torna significada, apenas imaginada (despretensiosamente imaginada, setenta vezes sete alisada em sua superfície). E aí ela não detém, em sua rijeza, o que se imagina por ela - assim, como quando é possível imaginar pássaros, cavalos-marinhos, longas barbas ou monstros inexistentes nas nuvens, tudo o que se quiser: seu aço aceita a delicadeza da imaginação, o algodão da flanela que o alisa, mil movimentos sejam, por mil maneiras, mas apenas no verniz das coisas - muito aquém ou além, portanto, da broca perfurante das significações que sempre quer aquele longo e profundo mergulho. O momento mais legítimo da imaginação é, pois, aquele em que o limite é pensado como dobra, onde a exterioridade e a interioridade inexistem, entre o pensável e o impensável: vale a fronteira embrulhada - no insistente, no subsistente. Num simples Aroma de mirra, de aloés e cássia exala de tuas vestes, desde as casas de marfim (em "Botão-deRosa") ou num E vi um céu novo e uma terra nova; porque o primeiro céu e a primeira terra se foram, e o mar já não é (em "Epidólia") há essa dureza que Rubião gostava. Não adianta dizer o que se vê: o que se vê não habita jamais o que se diz: ao abrir a letra, aparece a imagem; mas a imagem demanda algo que já não pode ser explicado pela letra. Sua autossuficiência não está em ser estranha em demasia para nunca dar conta do que se conta (como se viu, algumas epígrafes até têm bastante sintonia com o tema de seus respectivos contos), mas em ter uma dureza plástica que simplesmente transcende o que se conta, amassando-se, minorando-se em torno de si mesma. Imagens brutas, puras, duras, atômicas para a imaginação do leitor, não para a significação. Vê-se nisso como não é de bom tom o intento de torná-las absolutamente consoantes, casadas com os contos. E não há melhor forma, nenhuma linguagem objetiva e positivamente comportada que amplie tão severamente esse horizonte de pensamento: ao baterem no casco do barco, essas ondas móveis, moles e velozes se tornam tão duras quanto um muro de ferro: cabe imaginá-las. Sabem-nas muito bem alguns leitores da Bíblia. 
O autor sentiu, viveu e pensou o âmbito religioso como muitos outros autores - podendo afirmar, sobre si próprio: "Jamais consegui me livrar do problema da eternidade, chegando mesmo, na infância, a ser religioso e um tanto místico. O ateísmo, mais tarde substituído pelo agnosticismo, provocou em mim uma ruptura violenta". 92 Sem dúvida, "inspirou-se" no vivido, partiu de estados perceptivos e afetivos; porém, para ultrapassá-los, para aceder a outros tipos de percepções e afecções, aqueles tipos outros que excedem todas as vivências, dando às sensações uma vida própria. Mas, para além do que é ortopedia confessional, como a questão da eternidade, há outro dado sobre o autor: Rubião foi um assíduo leitor da Bíblia, como confirma Lomelino Couto, seu amigo próximo, com certo exagero: "Ele usava sempre a Bíblia, tinha uma cultura de Bíblia extraordinária". ${ }^{93}$ Rubião foi um leitor que aos poucos se descomprometeu do modo de leitura religiosa convencional para encontrar numa fantasia muito particular de leitura uma fantasia muito particular de escritura. Que fantasia de leitura, neste caso? Talvez, a de ler diferentemente, muitas vezes, o mesmo - como consciência inserida nos níveis literários dos poemas e das narrativas bíblicas (os debates atuais sobre o estatuto do leitor dificilmente dispensariam aqui o uso do termo processo ou do termo resposta para marcar esta área do leitor bíblico: movimento de ângulos, leituras como releituras, leituras de leituras, descoberta contínua de linguagens): "Minha opção pelo fantástico foi herança da infância, das intermináveis leituras de contos de fada, do Dom Quixote, da História Sagrada e das Mil e uma noites". ${ }^{94}$ A herança se transfigurou, em trânsito: quem sabe, de um fascínio infantil por "mensagens" a um fascínio adulto por tipos de fantasia e modos de inexpressão do Livro; nesta disposição, já uma leitura desgarrada das proposições religiosas (pelo menos das institucionais), uma leitura laica que se manteria até o fim, talvez sem tréguas, sobretudo por uma questão simples de gosto: o Livro como livro, constituído por poemas, sagas etiológicas, oráculos, ditos sapienciais, histórias, narradores, personagens - apresentando-se como composição. No que isso pode corresponder a uma perspectiva semelhante à perspectiva bíblica de um Erich Auerbach, por exemplo, ou a um interesse poético-bíblico próximo ao de um Northrop Frye, um Frank Kermode, um Harold Bloom, um Jack Miles, um Robert Alter ou um Haroldo de Campos, absolutamente nada pode ser afirmado, sendo mais prudente, inclusive, entender Rubião como um mero leitor; mas é interessante observar, oportunamente, que ele parece ter passado a entender a Bíblia como

\footnotetext{
92 J. A. de Granville Ponce, "Entrevista - O fantástico Murilo Rubião", in Murilo Rubião, O pirotécnico Zacarias. São Paulo: Ática, 1998, p. 4.

${ }^{93}$ Depoimento sobre Murilo Rubião, disponível no Acervo de Escritores Mineiros (UFMG).

94 J. A. de Granville Ponce, op. cit., p. 4.
} 
literatura, como quando faz este manejo de textos vários banindo fronteiras convencionais de espécie, colocando, num único repertório, de uma só vez, os contos de fada, o Dom Quixote, a Bíblia e o Mil e uma noites.

Da leitura irreligiosa à escrita literária, um passo: a fantasia da leitura como ato de imaginar - e a imaginação transformada, enfim, em fantasia de escritura. Mas que fantasia de escritura? Dizer "fantástica", como o autor diz sobre a "herança", não significa dizer algo superior ao silêncio: a terminologia não pode se fazer ouvir senão passando à "desordem" literária. Aí, sim, saindo do problema da "função" das epígrafes bíblicas e entrando no problema da fantasia de escritura como um todo, é possível dizer que ela às vezes se arraiga numa insignificância que figura superficialmente, beirando as pirotecnias bíblicas do imaginário nas quais não se divide x e y, o realizável e o imaginável, nem se supõe negligências entre o conhecido e o desconhecido, o finito e o infinito. Isto, diga-se, sem confundir aqui as dimensões pirotécnicas do texto bíblico propriamente dito (dimensões que, aliás, não se colocam num campo de "verossimilhanças") com as interpretações em sensosignificado que se deram e se dão nas inúmeras tradições judaico-cristãs, dentro e fora da Bíblia: homens de fé, hebreus e cristãos tentaram e tentam decidir os significados de suas próprias imagens (símbolo do corpo: "Isto é o meu corpo, que é para vós"); homens de imaginação, não decidem senão o mistério de suas próprias imagens (figura do pão: "Isto é isto, que é para vós"). Tem-se em cena, portanto, não as encíclicas papais ou alguma noção de sola fide, sola scriptura, solo Christus, sola gratia e soli Deo gloria, mas apenas algo em torno do texto bíblico, o que implica em Rubião, é claro, tons responsivos variados. Há, por exemplo, procedimentos estilísticos ou linguísticos semelhantes aos que são muito efetivos na literatura bíblica. Ao indiviso corresponde um modo de não-dizer: às vezes, nasce da própria construção fantasista que se impõe por relatos abruptos e enigmáticos, iluminando somente o que é muito importante, deixando no escuro o âmbito dos detalhes, exigindo uma leitura a ser livremente construída, como em "A lua", "Alfredo", "Epidólia" ou "Petúnia"95; às vezes, surge de dispositivos de paralelismo pulverizados ao longo de um conto [o paralelismo

\footnotetext{
95 Aqui, pensa-se Rubião numa perspectiva semelhante à de Auerbach sobre os relatos bíblicos, quando os contrasta com os relatos de Homero (a despeito de Auerbach ter em mente não o problema poético da autonomia dos relatos, mas um conceito historicista da mímesis, muitas vezes em sua acepção patrístico-escolástica de figura): "O mundo dos relatos das Sagradas Escrituras não se contenta com a pretensão de ser uma realidade historicamente verdadeira - pretende ser o único mundo verdadeiro, destinado ao domínio exclusivo": Erich Auerbach, "A cicatriz de Ulisses", in Mimesis, São Paulo: Perspectiva, 2009, p. 11. Importa dizer, com termos semelhantes: alguns contos de Rubião, assim como alguns relatos bíblicos, são tirânicos, não procuram o favor do leitor, não querem agradá-lo, mas simplesmente dominá-lo. Cf. também, sobre Auerbach, Moacir Amâncio, "A fulguração de Ana”, in Revista de Estudos Orientais, FFLCH/USP, v.5, p. 119-126, 2006 e João Adolfo Hansen, "Mímesis: figura, retórica \& imagem", in V Colóquio UERJ: Auerbach, Rio de Janeiro: Imago, 1994.
} 
(fonético, léxico, gramatical, semântico), sabe-se, é um fenômeno linguístico muito visível na literatura bíblica; daí que se tenha um conceito já muito conhecido e consagrado: "paralelismo bíblico"]; às vezes, sustenta-se em alusões amelódicas, pertencentes também ao imaginário interpretante, e já o desarticulando, como no conto "Botão-de-Rosa", em que o protagonista caricaturesco (no corpo: longos cabelos [...] barba; nas vestes: túnica branca, bordada a ouro [...] calças de um tecido azul com tachas prateadas [...] cinturão de fivela dourada [...] sandália [...] anéis [...] colares), acusado de ter engravidado todas as mulheres da cidade e, depois, de ser traficante de drogas, passa por um estranho processo de julgamento, com nuanças públicas semelhantes às do julgamento de Jesus (Nesse instante, em frente à Delegacia, a população começou a vociferar: Lincha! Mata! Enforca! - este trecho do conto, como em Lc 23.21: "Mas eles gritavam: 'Crucifica-o! Crucifica-o!"). Em "Botão-de-Rosa", aliás, os companheiros do "conjunto de guitarras" do protagonista são exatamente doze (Molinete, Zelote, Judô, Pedro Taguatinga, Simonete, Bacamarte, André-Tripa-Miúda, Ion, Mataqueus, Pisca, Filipeto e Bartô), como eram doze os apóstolos; Botão-de-Rosa também é traído por um deles, através de uma carta de denúncia, anônima (o laudo da perícia, com um "minucioso estudo grafológico", aponta ser Judô o autor da carta); enfim, é condenado à morte, como Jesus. Não se deve negar que é um conto apenas pitoresco e simples. Nem mesmo a biblicidade ou a apostolicidade de alguns desses estranhos nomes próprios, que facilmente possibilita combinações externas de toda sorte, deve incomodar seriamente o leitor: é apenas uma das muitas invencionices rubianas, quase sempre um mero estrebuchamento: por exemplo, para alguma diversão rococó, com humor, nos possíveis encaixes dos nomes próprios em "Botão-de-Rosa", assim: Zelote, como um possível membro dos zelotes, o movimento político-religioso mais radical do tempo de Jesus; Judô, como Judas, é claro, o traidor de Jesus; Pedro, como um impensável discípulo, talvez, taguatinguense, de Taguatinga (hoje, cidade do Tocantins ou uma região do Distrito Federal); André-Tripa-Miúda, como o apóstolo André, irmão de Pedro, que, apesar do ilustre parentesco com o importantíssimo Pedro, tem nos evangelhos um papel miudinho; Mataqueus, como uma corruptela de "macabeus", do Antigo Testamento; Filipeto, tomado a partir do apóstolo Filipe, como um apóstolo em miniatura, talvez. E os outros músicos do conjunto? Ora, os outros são os outros - e só (articulação e desarticulação pelos nomes: o modo de alternância que insta sugestões e ao mesmo tempo impede que as sugestões se tornem absolutas). ${ }^{96}$ Como escreve Benedito Nunes, agora pensando "não-senso" como

\footnotetext{
${ }^{96}$ Por isso, é difícil pensar sobre os nomes das personagens rubianas como se pensa, às vezes, sobre os nomes próprios em Guimarães Rosa (em "Buriti”, por exemplo, com o Chefe Zequiel, corruptela do nome do profeta bíblico).
} 
"absurdo": "o não-senso das palavras equivale aqui ao não-senso das situações". ${ }^{97}$ De fato, os nomes das personagens rubianas, em todos os contos, são sempre tão esquisitos, que não raramente surgem estudos acadêmicos sobre "os nomes" das personagens (diz-se: o nome próprio só idealmente é não-descritivo). Todavia, esse esforço limitado aos nomes quase sempre leva a um incômodo burlesco, semelhante ao burlesco em que se confunde LéviStrauss, por exemplo, com o dono da fábrica de jeans. ${ }^{98}$

Sobre os dispositivos de paralelismo, com sutilezas de linguagem muito semelhantes às dos paralelismos bíblicos (como a repetição de trechos ou o arranjo fantasista por duplas formações imagéticas), destaque-se: em primeiro lugar, que não se trata, é óbvio, de uma exclusividade da prosa rubiana (é um fenômeno estilístico geral, presente em muitíssimas literaturas); em segundo, que Rubião não fez exatamente "cópia" de paralelismos bíblicos, pois o "bíblico" aqui só tem relevância na medida em que se tornou fantasia de escritura, estando então generalizado como procedimento de linguagem. São vários os tipos de paralelismo na Bíblia ${ }^{99}$ : em linhas gerais, consistem em sintonias diferenciadoras de sons, palavras, frases ou ideias num mesmo perímetro textual, ou, com a mesma intensidade, na repetição de um som, de uma palavra, de uma frase ou de uma ideia com algumas variações (às vezes, ocorrem ecos e acentos em vez de rimas, ou uma desarmonia num contexto harmonioso, cuja apreensão exige do leitor, em alguns casos, domínio do hebraico e do grego). Veja-se, como exemplo de sintonia diferenciadora, este estranho trecho do livro de Juízes: "Disse-lhe ele: 'Dá-me um pouco d'água, peço-te: tenho sede.` Ela abriu o odre onde estava o leite, deu-lho a beber e o cobriu de novo" (Jz 4.19). Sísara pede água, Jael lhe dá leite: há uma beleza plástica aqui, ou insólita, ou absurda, leite por água. Porém, há também um possível nível de significado, apontado somente adiante, no capítulo seguinte do mesmo livro: "Bendita entre as mulheres Jael seja (a mulher de Héber, o quenita), entre as mulheres que habitam em tendas, bendita seja ela! Ele pediu-lhe água: leite lhe trouxe, na taça dos nobres serviu-lhe creme" (Jz 5.24,25). Quer dizer, Sísara pediu simples água, mas recebeu

\footnotetext{
${ }^{97}$ Benedito Nunes, “O convidado”, in Revista Colóquio, Lisboa, v. 28, p. 91, novembro 1975.

${ }^{98}$ Lévi-Strauss conta com muita graça que, durante a sua permanência nos Estados Unidos, ao apresentar-se na New School, recomendaram-lhe uma mudança de nome para Claude L. Strauss: "O senhor não pode chamar-se Lévi-Strauss de jeito nenhum", "The students would find it funny". E então observa, tendo entendido desde aquele tempo o problema da homonímia, sobre a sua situação atual: "Não se passa um ano sem que eu receba, em geral da África, uma encomenda de jeans": Claude Lévi-Strauss, De perto e de longe, Rio de Janeiro: Nova Fronteira, 1990, p. 44.

${ }^{99}$ Cf. Robert Alter, "The dynamics of parallelism", in The art of biblical poetry, Berkeley: BasicBooks, 1985; Adele Berlin, The Dynamics of Biblical Parallelism, Bloomington: Indiana University Press, 2008; Haroldo de Campos, "Paralelismo e sofisticação", in Bere'shith: a cena da origem, São Paulo: Perspectiva, 2000; James L. Kugel, The Idea of biblical poetry: parallelism and its history, New Haven: Yale University Press, 1981.
} 
saboroso leite, em nobre taça ${ }^{100}$ : o paralelismo se configura no nível da repetição das palavras e da diferenciação sintática (bendita entre ... seja; entre as mulheres ... bendita seja ela!), mas também no nível global da composição: pediu pouco, recebeu muito. O problema é que o arranjo foge completamente dos hábitos correntes: neste mundo hebraico, água é o único elemento que a sede exige (sede requer água - e nada mais), enquanto leite (coalhada) é um dos elementos exigidos pela fome (fome requer, entre outras coisas, leite). Trata-se, assim, de algo que dificulta uma decisão em termos de senso-significado, como se a produção do texto, alheia à necessidade de "informar", estivesse preocupada apenas com os seus traços formais de paralelismo (no caso, fonéticos, no jogo da língua hebraica água-leite): tem-se então uma espécie de contrassenso. Em Rubião, embora haja neste assunto um campo fertilíssimo para estudos específicos e mais dedicados, é possível dizer, generalizadamente, que os paralelismos são mais tortos, anuviados: por exemplo, blocos repetidos de frases (levemente modificados), como em "O pirotécnico Zacarias": A principio foi azul, depois verde, amarelo e negro [...] Sangue pastoso, com pigmentos amarelados, de um amarelo esverdeado, tênue, quase sem cor (em que a palavra "tênue" é subtraída à frente, na repetição do bloco, poucas linhas depois); "flor de vidro", "flor azul" e, como se viu, muitas outras formações duplamente imagéticas, na história de Eronides e Marialice; um bailar de prosa que se reveste de verso musical, prosa antiprosa, poema em prosa, empregando, entre outros recursos, certo paralelismo de lances visuais e sonoros, como neste forte (e florido) trecho de "Petúnia":

Quando dos pequeninos túmulos, colocados à margem da estrada, saíram os minúsculos titeus, nada mais pertencia a Éolo. Cacilda se assenhoreara do seu talento, das suas recordações. Proibira-lhe visitar os jazigos das meninas, levarlhes copos-de-leite, azáleas. Vedou-lhe o jardim, tomou-lhe o binóculo. É que apareceram os timóteos, umas flores alegres, eméritos dançarinos. Divertiam as miúdas Petúnias, brincando de roda, ensinando-lhes a dança, despindo-se das pétalas. A sua nudez aborrecia Cacilda. Sem protesto, Éolo aguardava as begônias, naquele ano ausentes. ${ }^{101}$

Para além de supostos procedimentos de linguagem, deve-se dizer: cá, lá, em sentido amplo, sempre existe em Rubião alguma construção fantasista que se assemelha muito propriamente ao que é de feição bíblica, como registram alguns estudos. Mas Schwartz entendeu isso muito seriamente, a partir da ideia de "ideologia do fantástico", "contextos

\footnotetext{
${ }^{100}$ Segundo nota da Bíblia de Jerusalém, leite ou creme trata-se aqui de leben, a coalhada dos nômades.

${ }^{101}$ Neste trecho, relevantes são: do ponto de vista do paralelismo sonoro, a simetria fônica das palavras túmulos, minúsculos, éolo, binóculo, timóteos, a marcação sincopada pela constância da oclusiva /t/, o uso excessivo dos pronomes oblíquos átonos proibira-lhe, levar-lhes, vedou-lhe, tomou-lhe, ensinando-lhes, todos esparramados no curto segmento; do ponto de vista do paralelismo léxico e visual, a profusão intencional dos nomes de flores: petúnias, titeus, copos-de-leite, azáleas, timóteos, begônias, mas também algumas expressões afetivas: "jazigo das meninas", timóteos que são "flores alegres", "eméritos dançarinos", "brincando de roda", "ensinando-lhes a dança", "despindo-se das pétalas", "sua nudez" etc.
} 
culturais": "A linguagem do fantástico adquire funções que se projetam além do texto ficcional, para vincular-se a séries culturais de ordem universal". ${ }^{102}$ Assim, um dos contextos culturais em Rubião estaria ligado a um "texto cristão" (os outros seriam o "texto social" e o “texto existencial”), possuído de conotação ideológica, lido em seus símbolos, no qual o "pensamento cristão" e o "sistema de oposições binárias, próprias da cultura judaico-cristã" estariam filtrando algumas narrativas: os elementos fantásticos estariam veiculando um subtexto cristão (por exemplo, ele diz, nos contos "A lua" e "Botão-de-Rosa"). Schwartz considera que a fantasia rubiana comporta toda uma série de categorias (como as de gênese, ordem universal, contexto, signos transparentes) que revela o seu "cristianismo". Com se vê, ele entende o caso de forma muito diferente da forma como se entende o caso aqui. Por ser absolutamente evidente a impossibilidade de se definir, assim, o que é "o pensamento cristão" ou o que é "próprio da cultura judaico-cristã”, em qualquer tempo ou espaço, em qualquer situação, em suas incontáveis facetas, bíblicas ou extrabíblicas, oficiais ou heréticas, centrais ou periféricas, vaticanais ou paroquiais, não se pensa aqui em termos de "ideologia" ou de "leitura ideológica", mas apenas em termos de fantasia de leitura bíblica que por vezes, somente por vezes, se relaciona com uma fantasia de escritura. Que as leituras bíblicas tenham dado ao autor alguma força desejante não significa que por elas a literatura criada se revele ou se defina, especialmente não como subtexto ou texto "cristão": o querer-escrever que se alimentou vez a vez de leituras bíblicas certamente se conduziu híbrido: com efeito, uma fantasia de escritura flertando muitas e distintas fantasias de leitura.

$\overline{102}$ Jorge Schwartz, Murilo Rubião: a poética do uroboro, São Paulo: Ática, 1981, p. 75. 


\section{V - O PAR ÍMPAR}

Não é viável tirar a pele, comer os nervos, lamber os ossos, chupar o tutano. Problema analítico: nele, às vezes são necessárias exatamente intervenções "anexatas", limitadas no máximo à epiderme, à derme e à hipoderme, para experimentar a Coisa exatamente. A matéria plástica, com suas moles liquefações que se solidificam assim que são tocadas, tanto requer uma forma particular de experiência, na superfície das coisas, quanto não sabe se contentar com uma língua passe-partout. Que algum pensamento sobre o não-senso rubiano não seja separável do próprio não-senso, que ele o hospede em si, é facilmente explicável: o não-senso artístico exige certo não-senso crítico: o interdito aspira interditos, algumas operações sintáticas precárias a serem entendidas apenas como não-senso, traços mudos, talvez nem ainda meramente gráficos, entre os pequenos fascismos ordinários da linguagem $(\mathrm{A}=\mathrm{A}$ como um não-signo ou signo vazio - e não como uma operação de significação), invisíveis traços algébricos, na apreensão das condições da impalpabilidade. Bem entendido que operações sintáticas desse estilo fazem valer os seus direitos lógicos articulando-se por uma força asignificante, num instante, faz-se necessária a pergunta: será que o pensamento em Rubião pode ser "certo", como é certo para uma abelha construir o seu favo em células hexagonais? O perigo de não fazê-la já é conhecido: didatismo que se impõe como discurso crítico excessivamente límpido, organizado, nunca interrogando as pressuposições políticas que o governam, nunca se arriscando num mínimo ato de pensar contra si mesmo - embora o "crítico" seja sempre o delfim de sua criação. Um curioso sistema de ideias, ou de linguagem, ou de organização (as três coisas ao mesmo tempo, talvez), está implícito nalguma superfície rubiana: não se exige nem se espera voos ou mergulhos. Defronte da personagem que é viva e morta ao mesmo tempo, ou da que chega num andor, escoltada por padres sardentos e mulheres grávidas, ou da que se incendeia e desaparece, ou da que se transforma numa bolinha negra, ou da que se torna o verbo resolver, lateral é o fado do intérprete, muitíssimo lateral. Nos extremos, nunca desprezando que se fez opção por uma maneira de tratar pragmaticamente as pirotecnias, aplica-se o que escreveu Barthes: "Nietzsche ligou sentido e força: o sentido (fruto, apelo à interpretação) é sempre um golpe de força. Em termos radicais: não há outra saída para a arrogância a não ser a suspensão da interpretação, do sentido". ${ }^{103}$ De fato, a única reação realmente viável seria uma reação de estirpe grega, pré-socrática: o pensamento se faz exatamente quando se posiciona estupidificado, abobalhado, extasiado, no

\footnotetext{
${ }^{103}$ Roland Barthes, O neutro, São Paulo: Martins Fontes, 2003, p. 321.
} 
assombro das coisas, tal qual o leitor diante de um grande problema imagético solta, afirmativamente, um “ai de mim!”. O que dizer, nele, então, aos que amam e exigem certezas, decifrações, profundidades, esquemas, organogramas, tutanos? Há uma obsessão pela "verdade" (e a significação nada mais é do que uma "condição de verdade"), mas por que não, de preferência, a incerteza ou mesmo a insciência? Que esta literatura tem alguma natureza "quântica" já é notório: nela, há aleatoriedades, ocorrências avulsas, conjunções e disjunções simultâneas, dinâmicas incertas, coisas que não devem ser pensadas no newtonianismo da significação: as "pétalas", o "branco", a "flor". Rubião está no domicílio das manias fantasmagóricas, ora afirmadas, ora negadas, ora sublimadas, ora distorcidas, ora travestidas, como bolhas nômades, que medusam onde quer que "sejam" (especialmente por se disfarçarem numa linguagem simplíssima, murmuradas por uma sintaxe doce), igualmente suficientes em si: ele não se reduz às leituras "unívocas", "óbvias", nem às "unidirecionadas" (como a que se tentou fazer em "A flor de vidro", por exemplo, ao passo que era possível se iludir num movimento ausência/presença), se é que tais leituras devem sobreviver nele - e não devem. Pois vez a vez não há escapatória: a noite do saber. Certas pirotecnias são "ilegíveis", se por "legível" se entende aquilo que se oferece a uma sólida decisão em termos de sensosignificado.

Mas, sim, pensou-se ao longo desses capítulos alguma coisa - embora a inexatidão das análises quisesse sempre produzir um pensamento delicado, um pensar sem dar dano à inexatidão da pele. A partir de alguns contos e das epígrafes bíblicas, pensou-se o não-senso num campo conceitual que resguarda em Rubião tanto a ideia de imagem pura quanto o âmbito de algo intransitivo, indizível, intraduzível. Sobretudo, é claro, criaram-se cenários de experiência. Dever-se-ia ter pensado, simultaneamente, o problema de algumas personagens rubianas - o que, porém, só é possível agora, neste último instante (tenha-se, então, que a geografia da sequência das páginas não permite a simultaneidade que requer a geografia do pensamento e que a geografia organizacional dos capítulos não geografa o que se dá por séries, essas zonas intercambiantes, os enredos, as personagens): a pele, nelas. Eis o recinto no qual o problema sempre se colocou e novamente se coloca: experiência num horizonte de pensamento. Mas, enfim, pensamento numa espécie muito precisa de personagens, o que exige tratá-las experiencialmente como espécie, mas inevitavelmente em termos de alguma discussão sobre personagens de ficção em geral. Este é, pois, um capítulo final que tenta se situar, mesmo que muito rapidamente, nas modalidades de pensamento que determinadas personagens impensáveis parecem aguardar, sintonizando-as com a questão do não-senso. 
Não se trata de investigar e definir "como elas são" tendo como parâmetro, baliza ou leme uma indiscutível verdade extratextual, não especialmente da mesma forma em que se identifica e se explica traços determinantes a partir de uma ideia de "pessoa" (esta, a busca de cada "essência" ou "existência", no âmbito, de cunho sartreano, em que já foi muito polêmico se discutir se a essência precede a existência ou se a existência precede a essência), tal como se diria, assim, em rótulos sintéticos, qualificantes: em Angústia, de Graciliano Ramos, Luis da Silva, o narrador-protagonista tímido e solitário, e Julião Tavares, o gordão risonho e bemsucedido; em "Noite de almirante", de Machado de Assis, Deolindo, o marujo apaixonado, e Genoveva, a espertinha. Dir-se-ia, então, "tímido", "solitário", "risonho", "bem-sucedido", “apaixonado" e "espertinha" quando tais qualificações vertessem dos próprios textos literários (o que nem sempre é o caso), padecendo, contudo, na territorialização polissêmica das palavras - ou quando fosse possível crer que há paradigmas universais para tais adjetivações (o que nunca é o caso), padecendo, contudo, na desterritorialização permanente dos paradigmas. Também não se trata de examinar, com o legado crítico de matriz proppiana, a funcionalidade das personagens, embora esteja aí algum mérito de contrariar excessos psicologistas e sociologistas; foram os formalistas russos os primeiros a proporem que os seres narrativos não se explicam em suas relações de semelhança com uma ideia de "ser vivo"; escreveu Tynianov: "Abandonamos este tipo de crítica que consistia em por em causa e em julgar os personagens do romance como seres vivos". ${ }^{104}$ Não se trata de estudar, com Edward Morgan Forster, se as personagens são "planas" (por uma ideia ou qualidade, tipificadas, lisas, estáticas, concentradas num único fator) ou "redondas" (por várias tendências, complexas, dilatadas ao extremo, multiformes, repelindo toda a simplificação); ou de assimilar, com Algirdas Julien Greimas, uma semântica distributiva de "atores" e "actantes", identificando as personagens por sua atuação; ou de deduzir, com Claude Bremond, uma "lógica narrativa", através de postulações também funcionalistas sobre as personagens; ou de investigar, com Philippe Hamon, um estatuto semiológico das personagens, para definir se são "referenciais" (remetendo para um significado pleno e fixo, imobilizado pela cultura), "embrayeurs" (remetendo para um significado relacional com os outros elementos da narrativa) ou "anáforas" (remetendo ao próprio sistema da obra); ou de acompanhar, com Fernando Segolin, uma classificação das personagens, definindo, assim, cada espécie e momento: "personagem-aristotélica”, “personagem-função”, “personagem-

\footnotetext{
104 J. Tynianov, “A noção de construção", in Eikhenbaum et al., Os formalistas russos, Porto Alegre: Globo, 1978, p. 100.
} 
estado", "personagem-texto" ou "anti-personagem". ${ }^{105}$ No horizonte de pensamento potencializado por algumas personagens rubianas, nem sequer seria adequado enquadrá-las em uma moldura metodológica (assim se faz, às vezes, simplesmente: como se nelas certos padrões pudessem ser discernidos e esquadrinhados ou como se o propósito de apreendê-las em formas rígidas de pensamento fornecesse o modo ou o meio de domá-las, encarcerá-las). Neste horizonte, a mais alta aspiração intelectual seria nada dizer, nada como significação, nenhuma operação sintática: imaginação. Mas, se o dever crítico exige uma linguagem crítica, afirme-se: todo o pensamento precisa atuar, pois, de uma forma que, num empirismo que saiba ultrapassar a explicação sem cair no misticismo, possa corresponder aos entes do nãosenso artístico: pensar o impensável - um ato de pensar que não emerge sem uma nova imagem do pensamento. Algumas personagens pirotécnicas são extra-seres: "eus" larvais e terminais, pensáveis e impensáveis, seres do pensamento impensável [mas eis então, no próprio pensamento que as predefiniu agora como extra-seres, o paradoxo no qual repousa todo o enigma do pensar (problema do não-senso crítico): pensa-se também o impensável]. Faça-se um recorte: o pensável-impensável Zacarias.

$*$

É um conto especialmente cômico. As coisas se dão de maneira muito simples, narradas quase sempre com um nível de tensão à beira do apenas pitoresco, raso, ralo - novamente, história-bestice. Mas eis em Zacarias uma lógica alógica: a despeito da conhecidíssima tópica luciânica e machadiana dos mortos que falam ou relatam, Zacarias não é como o defuntoautor do Memórias Póstumas (que é narrador verdadeiramente post mortem): o artista pirotécnico narra a própria morte ocorrida num atropelamento estando numa condição de vivo-morto, condição paradoxal que o mantém em um tempo animado, entre os vivos: em verdade morri [...] por outro lado, também não estou morto. Com ele, este arranjo inefável onde a vida e a morte se reúnem ou a esquizofrenia de poder ocupar instantaneamente uma condição A e uma condição B torna-se plausível - e risível. Morri: não vivo mais. Não estou morto: ainda vivo. Ele é o gato de Schrodinger. ${ }^{106}$ Tenha-se, a princípio: um vivo é um "ser", assim como um morto é outro "ser", mas um vivo-morto é um extra-ser (ante mortem e post mortem ao

105 Cf. Vladimir Propp, Morfologia do conto maravilhoso, Rio de Janeiro: Forense, 1984; Edward Morgan Forster, "Pessoas" (capítulos 3 e 4), in Aspectos do romance, São Paulo: Globo, 2005; Algirdas Julien Greimas, "Reflexões sobre os modelos atuacionais", in Semântica estrutural, São Paulo: Cultrix, 1976 e "A estrutura dos actantes da narrativa", in Sobre o sentido: ensaios semióticos, Petrópolis: Vozes, 1975; Claude Bremond, "A mensagem narrativa”, in Roland Barthes et al., Literatura e Semiologia, Petrópolis: Vozes, 1972; Philippe Hamon, "Para um estatuto semiológico da personagem", in Philippe Hamon et. al., Categorias da Narrativa, Lisboa: Arcádia, 1976; Fernando Segolin, Personagem e anti-personagem, São Paulo: Olho d’água, 2006.

${ }^{106}$ Trata-se da conhecida experiência mental do físico-quântico Erwin Schrodinger. Tal como Zacarias, o gato de Schrodinger, fechado numa caixa com veneno, encontra-se numa "superposição de estados": vivo-morto. 
mesmo tempo). O leitor não pode alimentar uma dúvida sobre a morte, como fazem os amigos de Zacarias: Teria morrido o pirotécnico Zacarias? Pois mesmo os rapazes e as moças do carro que atropela Zacarias tanto aceitam a vida do morto (cadáver que fala com eles) quanto aceitam a morte do vivo (a veracidade física da morte). Tal dúvida absolutamente não cabe, quando o problema é mais complexo. Para responder à questão que fazem, os amigos se dividem entre uma frágil explicação laboratorial (a de que existe alguém parecido com Zacarias) - Uns acham que estou vivo - o morto tinha apenas alguma semelhança comigo [...] Ainda há os que afirmam de maneira categórica o meu falecimento e não aceitam o cidadão existente como sendo Zacarias, o artista pirotécnico, mas alguém muito parecido com o finado - e uma frágil explicação mística (a de que existe uma alma penada) - Outros, mais supersticiosos, acreditam que a minha morte pertence ao rol dos fatos consumados e o indivíduo a quem andam chamando Zacarias não passa de uma alma penada, envolvida por um pobre invólucro humano. Mas o que está em cena é uma pirotecnia, algo que introduz outro tipo de lógica: vivomorto. Deve-se pensar, pois, num ser impensável, que confessa: mesmo à margem da vida, ainda vivo. O paradoxo é possível no problema do tempo animado que não foi definitivamente abolido com o momento-morte: uma condição que seria, por assim dizer, "posterior" se harmonizou, sem intervalo, com uma condição que seria "anterior". Num desenho que pretendesse representar linearmente este arranjo de tempo e condições, seria possível traçar, a partir de um momento-morte, uma dobra para trás (pois o tempo da vida, isto é, Zacarias entre os vivos, continua), paralelizando e sobrepondo, assim, duas condições. Seu elemento genético e seu ponto-dobra seriam o atropelamento, o momento-morte, como retroflexão, a partir do qual todo o tema do conto se constrói: a experiência da morte, seguida do movimento retroflexo que torna vida e morte concomitantes, gerando um extra-ser, de caráter fantástico, que, pela perícia, também afirma: faço tudo o que antes fazia e, devo dizer, com mais agrado do que anteriormente. Mas este desenho linear, que paralelizaria e sobreporia um "antes" e um "depois", não seria suficiente. Ao pensar o tempo como uma linha reta composta de condições concomitantes (vida e morte), não é possível organizar os traços mnêmicos da personagem. Pense-se nas torções que deslocam a linha: o "anteriormente" dito por Zacarias, que pretende significar "antes da morte", torna-se no mínimo o cômico do cômico, pois, dada a dobra para trás, aquele momento-morte já não serve exatamente de referência linear para um "antes": tornaram-se vulneráveis, afinal, os traços de tempo que permitiriam um antes e um depois. Pense-se também que, como a condição vivo-morto faz Zacarias permanecer num tempo animado (entre os vivos), antigas percepções podem perfeitamente se misturar com percepções imediatas: daí que o narrador autodiegético possa interromper abruptamente o relato do seu atropelamento ("passado" próximo) para encaixar concomitantemente uma cena 
da infância, do tempo de escola ("passado" distante): Quando tudo começava a ficar branco veio um automóvel e me matou. - Simplício Santana de Alvarenga! - Presente! [...] - Tire a mão da boca, Zacarias! Quantos são os continentes? E a Oceania? Dos mares da China não mais virão as quinquilharias [...] Simplício Santana de Alvarenga! - Meninos, amai a verdade! O tempo em que vive-morre a personagem não pode ser definido numa concepção linear quando inclui desta forma o campo da memória: passado e presente virtuais e atuais não se colocam como momentos sucessivos, mas como estruturas temporais heterogêneas que coexistem: um monismo do tempo, não obstante o passar dos dias, dos meses. Na verdade, a condição vivo-morto é triplamente unívoca: proporciona-se simultaneamente em futuro, presente e passado, não se reduzindo a uma convenção cronológica. Trata-se de uma pirotecnia: matizes, curvaturas entremeadas, ecos de valências mnemônicas, o caminhar cômico para o "futuro", a preocupação com o destino do cadáver. Talvez (diga-se, não sem humor), um engenho redondo - cromático, performático, sonoro, carnavalesco, exigindo uma dinâmica de cores, formas e sons ininterruptos em cima do próprio círculo - pudesse ser um desenho mais conveniente. Emparelhadas, vida e morte comungam - perpetuamente. Afinal, para onde vai esta vidamorte? Morrer já não é o fim de tudo - e uma vida-morte certamente pode perdurar como máquinas de movimento perpétuo (frasco de auto-fluxo de Robert Boyle, roda de Bhaskara, roda de Villard de Honnecourt). ${ }^{107} \mathrm{O}$ vivo-morto é uma potência pirotécnica que substitui a rigidez do "pensável" propondo a simultaneidade ou a coexistência de futuros, presentes e passados incompossíveis: coordenações inexplicáveis, alternâncias indecidíveis. Decida-se, pragmaticamente: as leis newtonianas da significação não servem às leis zacarianas: o unicamente pensável morre, toda modalidade unicamente pensável desaba, em proveito de um pensamento impensável, paradoxal. Isso significa dizer que o extra-ser da condição vivomorto, a sua medusidade, é demonstrativamente impalpável: não se deve pensar esta personagem sem as incertezas e as aleatoriedades de um "tempo quântico". É o mesmo que dizer que não há começo, meio e fim, apenas tempo medusado: o que vem quando re-vem, o que vai quando re-vai - ou não. Numa palavra, algo acontece no pirotécnico, algo indemonstrável, incognoscível.

O vivo-morto Zacarias como o apenas humor vivo da morte, humorte? - fica-se no riso. A cada uma das singularidades do conto pode-se dar algum destino preciso: algumas envolvem a condição insólita do narrador-protagonista - cadáver que bebe, que anda pelas ruas, que narra a sua própria condição; outras envolvem as reações também insólitas de seus

\footnotetext{
107 As clássicas “máquinas de movimento perpétuo” (dispositivos ou engrenagens pensáveis-impensáveis) são objetos de pesquisa do físico Donald E. Simanek (Lock Haven University of Pennsylvania).
} 
atropeladores - rapazes e moças que conversam com o defunto, dão carona ao cadáver. Mas talvez este caráter visivelmente raso e ralo do pitoresco, até ser tomado por ingênuo, que propõe pensar as coisas apenas em termos de "fantástico" ou "absurdo", tenha impedido outrora de se pensar: o vivo-morto é um par ímpar, congrega a prática do Mesmo e do Outro; como as partículas subatômicas, propõe duas condições ao mesmo tempo: a ocupação de um ponto A para chegar a um ponto B, mas sem sair do A, e a projeção, enfim, de um movimento perpétuo - eis o que perturba o encadeamento lógico, exigindo outro tipo de lógica. Justamente, ao lhe conferir um lugar à parte (nem somente vivo, nem somente morto), o conto apresenta um extra-ser, pertencente a uma zona extra-empírica (a da experiência lógica) e não somente empírica (a da explicação laboratorial). Enquanto os unicamente "seres" são aqueles que, em seus atos, obedecem às leis gerais da coerência e, em suas frases, obedecem às leis gerais da língua, visando um "fora”, na língua, que é sempre um unicamente "pensável”, os extra-seres são figuras que ultrapassam qualquer forma convencionalmente explicável - sim, com sua lógica monística: em verdade morri [...] por outro lado, também não estou morto.; com sua língua estranha e única: Os filamentos brancos não tardariam a cobrir o céu. [...] Quando tudo começava a ficar branco veio um automóvel e me matou. [...] Simplesmente porque não seria naquela noite que o branco desceria até a terra. [...] e o branco já se aproxima da terra para exclusiva ternura dos meus olhos. Os princípios lógicos que regulam os seres não regulam os extra-seres: estes últimos solicitam uma lógica alógica, promovem uma espécie de contrato restritivo que não adere às matérias convencionadas, têm cláusulas leoninas ou exorbitantes, tramitando, diga-se, num mundo próprio, em outras categorias de ideias. Há, neles, sempre um excedente de fatos, falas, percepções ou gestos que os torna demasiadamente singulares: sabem algo inexprimível, vivem algo insondável, algo que se hospeda no vazio; mostram a insuficiência das leis demonstrativas. Visam também um "fora", mas um fora do modo de ser do discurso (por exemplo, o "branco"), algo que não deve ser discursivamente interiorizado como significação, entre o pensável e o impensável. Deste modo, eles insistem, subsistem - como operações alógicas, como outras formulações de pensamento, para além do "cômico" ou do "ingênuo". O unicamente pensável de um voyerismo microscópico do leitor é atravessado pelo impensável: uma fortaleza inamovível, quântica. Toda possibilidade de dissecação é dissecada pela intransitividade em que os extra-seres se realizam: a noite os circunda. Já não deveria haver a mínima possibilidade de pensá-los sem uma nova imagem do pensamento.

Considera-se em geral que a delimitação e o recorte dados por um texto às personagens (mediante descrições minuciosas ou mediante certo arranjo verbal e de eventos) são 
suficientes para o leitor defini-las (fisionomia, movimentos corporais, aspectos psíquicos, ideológicos - em protagonistas, antagonistas, coadjuvantes). De fato, o que se sabe sobre um Cariba, um João Gaspar, um Galateu ou um Pererico é o que os contos de Rubião apresentam sobre eles: mostram tendências caracteriológicas que os distinguem, além de trazerem traços de realidade (tal como se pensa no senso comum, reivindicando um conhecimento da realidade) ou ilusões referenciais (tal como se pensa um "efeito de real", reivindicando um conhecimento da linguagem). Está-se então num "como elas são" definido por identidade ou semelhança ao que se tem como verdade ou consenso, submisso aos pontos de vista de leitores evidentemente expectantes, muitas vezes ávidos por capturá-las em medidas balzaquianas ou alencarianas: uma rapsódia de "pessoas". Com um inegável contorno antropomórfico, mesmo quando a insistência é distinguir personagem (ser ficcional) e pessoa (ser vivo), sinopses de perfis são construídas, não raramente imbuídas de propensões classificatórias, sob a troca metalinguista em que uma caracterização, a de uma invenção do texto, é tomada por outra caracterização, a de uma convenção cultural e histórica (ser aquiloali significa ser isto-aqui: como espécies aliadas, homo fictus e homo sapiens). As personagens assumem assim algum status universalizante. O que comumente se diz: representam "pessoas", são sósias dos seres humanos, em sua físionomia físico-moral, em sua inserção num universo de problemas semelhantes aos dos seres humanos. ${ }^{108}$ Mesmo um Todorov - ao destacar que o problema da personagem é, antes de tudo, um problema linguístico, pois não existe fora das palavras - admite uma ideia de representação: "Uma leitura ingênua dos livros de ficção confunde personagens e pessoas vivas [...] Olvida-se então que o problema da personagem é antes de tudo linguístico, que ela não existe fora das palavras, que é um 'ser de papel'. Entretanto, recusar toda relação entre personagem e pessoa seria absurdo: as personagens representam pessoas, segundo modalidades próprias da ficção". ${ }^{109}$ A ideia de representação fornece a ordem própria ao pensamento, com suas regras e seus processos de recognição: Zacarias é um homem, Zacarias tem traços de homem. Assim como a mimesis aristotélica, em suas definições clássicas, por força da acepção éticorepresentacional que lhe foi conferida, tende quase sempre a ser entendida como que se referindo à elaboração de uma semelhança ou imagem da natureza, encontram-se numa ideia

\footnotetext{
${ }^{108}$ Estudos das personagens a partir da ideia "pessoa" podem ser encontrados, por exemplo, em trabalhos que têm base em premissas de cunho psicológico ou sociológico, como os de Zeraffa e Goldmann. Cf. Michel Zeraffa, Pessoa e personagem: o romantismo dos anos de 1920 aos anos de 1950, São Paulo: Perspectiva, 2010 e Lucien Goldmann, Sociologia do romance, Rio de Janeiro: Paz e Terra, 1967.

109 Tzvetan Todorov, "Personagem", in Oswald Ducrot e Tzvetan Todorov, Dicionário enciclopédico das ciências da linguagem, São Paulo: Perspectiva, 2001, p. 209-10.
} 
fixa de "ser humano" ou "ser vivo" os pontos de referência para uma explicação e um ajuizamento valorativo de personagens - em flat ou em round, por exemplo (pensa-se, então, em termos de "condição de verdade", que remete a conceitos universais e gerais: a identidade no conceito, a determinação no conceito, a analogia no juízo, a semelhança na personagem). Diz Candido: "o problema da verossimilhança no romance depende desta possibilidade de um ser fictício, isto é, algo que, sendo uma criação da fantasia, comunica a impressão da mais lídima verdade existencial. Podemos dizer, portanto, que o romance se baseia, antes de mais nada, num certo tipo de relação entre o ser vivo e o ser fictício, manifestada através da personagem, que é a concretização deste". ${ }^{110}$ A própria etimologia do vocábulo "personagem" assinala alguma restrição semântica: quando objetos (orgânicos ou inorgânicos; minerais, animais ou vegetais) são utilizados como protagonistas (na chamada "literatura do maravilhoso" existe uma porção deles), há um halo simbólico que, por personificação, subtrai-os dos círculos mineralógicos, zoológicos ou botânicos para alçá-los ao perímetro da persona $^{111}$, onde o leitor pode contemplar, através deles, a complexidade da sua própria condição. Em termos de mimese, tem-se a preocupação comum de autenticar um "real", partindo nesse caso de antecedentes tomados como irrefutáveis: verdade sobre o ser humano, verdade sobre o mundo real, verdade sobre o ser humano no mundo real etc. Daí também que já exista um conceito para o efeito artístico: "personagem-representação" ou "personagens representacionais".

Toda a ideia representacional se fundamenta no intento de alcançar pelo inteligível um objeto sensível. O problema é que alguns seres pirotécnicos de Rubião no mínimo embaraçam as analogias convencionais: o que é, exatamente, ser vivo-morto, ser a Intangível, tornar-se uma bolinha negra ou o verbo resolver? A ideia de que personagens "representam pessoas" é visivelmente modesta face aos extra-seres. Se eles fossem uma rapsódia de "pessoas", seriam facilmente esgotados por uma análise psicológica ou sociológica, quer essa análise se fizesse no estilo mecânico de uma psicofisiologia ou de uma sociofisiologia, quer no estilo de uma pesquisa por significados. Mas eles são, sem dúvida, algo diferente de uma rapsódia de "pessoas", pela simples razão de serem um engenho indigesto à explicação laboratorial. É o caso de dizer: às vezes, nisto, são irreconhecíveis: valem tanto mais quanto menos têm razão de ser. Que não devem ser tratados como são tratadas algumas personagens de Graciliano ou

\footnotetext{
110 Antonio Candido, "A personagem do romance", in Candido et al., A personagem de ficção, São Paulo: Perspectiva, 2000, p. 55. Cf. também Beth Brait, A personagem, São Paulo: Ática, 2006.

111 Não à toa, Greimas, por exemplo, substitui a designação "personagem" pela designação "ator" (entidade figurativa, animada, susceptível de individualização), ainda a diferenciando de um suporte sintático, "actante", dividido em seis (sujeito, objeto, destinador, destinatário, opositor e adjuvante).
} 
Machado fica evidente, levando-se em conta o seu lugar lógico: assim como a física de Newton é adequada para as coisas grandes, mas péssima para as estranhíssimas vicissitudes das infinitesimais atômicas, a ideia de "representar pessoas" pode ser adequada para um Luis da Silva, um Julião Tavares, um Deolindo ou uma Genoveva, mas péssima para os extra-seres rubianos: estão num campo lógico diferente. Advirta-se, porém, que uma insuficiência de raciocínio também é o limitar-se a dizer: neles, não é possível vislumbrar a suposta fisionomia apaziguadora do chamado "mundo real", das "pessoas reais", nem mesmo a fisionomia forjada num suposto "imaginário coletivo", nem ainda a fisionomia fisgada numa suposta personagem "sobrenatural" que simbolizaria uma suposta pessoa "natural", estando as personagens apoiadas não numa verossimilhança externa, mas numa verossimilhança interna, acentuando o texto como um organismo não resignado às recorrentes celebrações em torno do isomorfismo forma-conteúdo, as ações ou as ocorrências irrompendo por si mesmas e se convertendo numa dinâmica estruturante que, aliada ao fio narrativo, estrutura uma proposição de realidade absurda. Tal raciocínio é reducionista, não por acidente, mas por essência e necessariamente: faz dos "extra-seres" simplesmente o extremo oposto dos "seres", a partir de uma concepção do não-senso como "absurdo". Pois, também aqui, há pelo menos duas maneiras de tratar pragmaticamente as personagens pirotécnicas: quando se pensa no âmbito do senso-significado, elas são decididas como representação de seres vivos, como símbolos ou metáforas agudas, remetendo a conceitos universais e gerais, tornando-se entes antropomórficos a serem interpretados (não é inútil dizer: em senso-significado, segue-se a via régia: até uma simples "folha seca que cai" pode significar a efemeridade da vida humana, se assim se quiser); quando se pensa no âmbito do senso-sentido, no entanto, elas são decididas apenas como entes do não-senso (da assemia).

Retome-se algo afirmado no capítulo "Senso e não-senso", exatamente: a pirotecnia em literatura trai a significação tanto quanto a potencializa: a plástica imaginária da pirotecnia, com os significados que nela se decidem, não é senão a forma de um paradoxo (p. 45). No caso das personagens pirotécnicas, que paradoxo? O atual (Pessoa: o senso-significado, o dizível, o pensável) e o virtual (Coisa: o senso-sentido, o indizível, o impensável). Uma ilustração possível (não-senso crítico: não menos do que uma ilustração "anexata"): numa partida de xadrez, que às vezes dura horas, dias ou mesmo semanas, o chamado "movimento de xeque", lance que indica uma ameaça imediata ao "rei" adversário, objetivo máximo do jogo, está irredutivelmente colocado desde o primeiro minuto da partida; deve-se dizer, na peleja: ele é um devindo, um lance virtual (não existente: insistente, subsistente) que é 
continuamente atualizado no movimento das peças. Então: assim como a pirotecnia é relativa (polissemia) em sua dimensão atual $(\mathrm{A}=\mathrm{B}, \mathrm{C}, \mathrm{D})$ e absoluta em sua dimensão virtual ( $\mathrm{A}$ = A), uma personagem é um ser em sua dimensão atual (Zacarias é um homem) e um extra-ser em sua dimensão virtual (Coisa-Zacarias). Portanto, aquela ideia de representação se limita somente a um possível ponto de contato entre personagem e pessoa (tendo previamente um conceito canônico de pessoa), explora apenas uma efêmera dimensão atual, simbólica, a dos significados (sempre plural e móvel), remetendo a conceitos julgados universais e gerais: aí, como sugere Todorov, as personagens realmente podem representar pessoas. Pensa-se então que as personagens pirotécnicas abrem um falar não menos do que um ver, como se as significações habitassem o invisível e como se o invisível murmurasse as significações: em senso-significado, personagens pacificadas, redimidas, abençoadas como símbolos de realidade. De qualquer forma, tenha-se que os extra-seres representam pessoas, mas representam mal - e isto significa, exatamente: não representam, apenas fazem com que pensamentos sobre a "categoria pessoa" transitem neles, decisões pragmáticas em torno de significados. Então se diz: amam, comem, fumam, sofrem, sonham: têm marcas humanas (é assim que, mesmo sendo impensáveis, engrenam reverberações de toda ordem: o mimético, o realístico, o socialístico, o psicanalítico). Mas não há ideia de pessoa o bastante para os extraseres: eles são uma descaracterização da chamada "personagem-representação"; nada são senão o caos, a potência de afirmar o caos, ser-caosmo. Neles, nada é mais frágil do que uma tradição de leitura naturalista: permitem outro tipo de decisão pragmática. Desdobram-se em um mundo que encerra formas lógicas que não se deixam decifrar (lógicas alógicas): o fato de que seus gestos possam ser eventualmente interpretados, suas fisionomias, seus desejos, não impede o seu "quântico". Há em Rubião este habilíssimo modo de conferir extracompetência. Em geral, ele estiliza e recategoriza tipos, adaptando-os, esvaziando-os num fortíssimo mundo fantasista, como mistura monstruosa, conjugando seres para formar extraseres, impedindo que se fixem simplesmente como "pessoas". Sua ficção é, assim, dupla: personagens como tipos humanos (pirotécnicos, jornalistas, funcionários públicos), mas que, ao mesmo tempo, não se encerram nos tipos humanos: compensam os limites dos tipos pela medusagem, uma medusagem intransitiva. A crítica que não sai dos limites do efeito de real produzido no texto e pelo texto, que se reduz ao empenho de descobrir pontos de semelhança com a realidade, tem enorme dificuldade com eles: não cabem totalmente na moldura simbólica que lhes é dada, vazando, escorrendo, pingando. Se não é possível negar, por exemplo, que a ancoragem espaço-temporal (o emprego de topônimos e/ou cronônimos) e a 
debreagem interna (que referencializa um segmento discursivo, como uma passagem do diálogo à narrativa, ou inversamente) dão uma ilusão de "realidade", também não é possível ignorar as aporias: com eles, monta-se uma débâcle generalizada, que não permite a instauração automática entre o fundamento e a determinação: fragilizam-na, pois anulam a sua estratégia principal: a semelhança. Os extra-seres são, de fato, uma imagem desprovida de semelhança: vivo-morto.

Não é novidade que é possível explorar muitas zonas de indeterminação entre seres fictícios e seres vivos: ora se salienta a diferença que há entre o que se dá na ficção (seres da invenção, da linguagem) e o que se dá na realidade (seres dos fatos, da vida), que no mundo fictício as personagens obedecem a uma lei própria (deste ponto de vista, o homo fictus não é equivalente ao homo sapiens); ora se tem que na ficção e na realidade todo o conhecimento sobre personagens e pessoas é fragmentário, contraditório e relativo (no fundo, mera composição verbal, síntese de palavras), tomado por conjunções e disjunções, sempre colocado mais como projeção arriscada do que como detecção objetiva (deste ponto de vista, o homo fictus é equivalente ao homo sapiens: as personagens são tão indefinidas quanto são as pessoas em geral). Mas também é possível afirmar, numa decisão: certos engenhos literários são a expressão de um mundo que vale absolutamente por si, como matéria intensiva, mas assêmica, não simbólica, mundo em que extra-seres recortam e talham um território próprio: figuram (deste ponto de vista, as personagens são fluxos territorializados em si e desterritorializados fora de si: em algum momento, de alguma forma, são estrangeiras a qualquer ideia de "ser vivo" ou "pessoa"). Passadas as percepções primárias, deve-se buscar o direito de tomar o problema de outro modo, fazer outros tipos de perguntas, por cima, por baixo, ao redor ou ao lado das mesmas, pelas dobras, vieses, franjas: deslocar, retorcer, tolher - visto que o objeto clama. Pirotecnia: o que não se define como "absurdo", mas como nãosignificado; o que ultrapassa a explicação laboratorial, exigindo uma experiência lógica; o que não "existe" propriamente, mas insiste, subsiste, como formulação de pensamento: "círculo quadrado”. Na ideia de extra-ser, há a ideia de ser, mas os motivos de sua operação não convêm diretamente à expectativa existencial (a impossibilidade existencial do vivo-morto é em si absoluta e incondicionada, em qualquer situação), convêm à expectativa lógica (como diriam os estoicos: insistencial, subsistencial), na qual o extra-ser é apreendido como um ente do pensamento impensável. Os extra-seres são, assim, seres de pensamento como outras espécies de personagens, mas são os melhores seres de pensamento: aguardam o pensamento 
(e o aguardam tanto quanto o pensamento os aguarda); contudo, só precisam encontrar uma espécie de pensamento que não os aprisione em senso-significado: comungue, imagine, $a$ pense. Pode-se dizer, grosso modo, que o extra-ser é o ato locucionário, pensar é o ato ilocucionário e a-pensar é o ato perlocucionário. ${ }^{112}$ Trata-se de uma necessidade sigética. Eles se fazem no espaço de encontro onde o pensamento e o a-pensamento se entrecruzam: não, pois, apenas no “pensável” ou apenas no "impensável”, mas em cima desta fronteira de encontro.

Para respeitar os véus da lógica alógica e substituir pragmaticamente a explicação do saber pelo espanto da experiência é preciso algum "holocausto de ideias": descarregá-las, esvaziá-las, tratá-las a pão e água, penetrá-las de silêncio para aliviá-las. A verdade grega foi outrora abalada por esta única afirmação: "Eu minto" (paradoxo de Epimênides, o Cretense, a respeito da verdade e da mentira). Epimênides é cretense e afirma que todos os cretenses mentem: ele, então, mente se, somente se, não mente (isto é, diz a verdade); ele não mente (isto é, diz a verdade) se, somente se, mente. O vivo-morto Zacarias é uma personagem igualmente paradoxal que exige uma experiência lógica. Porém, aqui, é importante destacar novamente a maneira pela qual as coisas estão se colocando: enquanto que, numa explicação laboratorial, falar-se-ia sempre de "lógica" como um encadeamento demonstrativo (por exemplo: A < B e B > C = B > A e C), numa experiência lógica se fala de "lógica" como um trânsito no indemonstrável, uma relação com o impensável (lógica alógica - e não "ilógica", “absurdo"). ${ }^{113}$ Não é algo místico: há uma lógica do virtual, uma lógica do acontecimento, uma lógica da pirotecnia, uma lógica do senso-sentido, uma lógica do extra-ser - mas eis que não pode ser senão uma lógica alógica, uma lógica que ultrapassa radicalmente a lógica

\footnotetext{
${ }^{112}$ A comparação se situa nas dimensões da célebre "teoria dos atos da fala" de John Langshaw Austin. As nomenclaturas são pesadas, mas são as que Austin usa: ato locucionário (a ação linguística), ato ilocucionário (a função da ação linguística, o que a ação linguística quer) e ato perlocucionário (o efeito da ação linguística, o que a ação linguística de fato produz). Cf. John Langshaw Austin, Quando dizer é fazer: palavras e ações, Porto Alegre: Artes Médicas, 1990.

113 Talvez não se tenha exemplo mais intenso de "experiência lógica" do que a do conhecido matemático Georg Cantor a respeito do chamado continuum matemático ou teoria do infinito matemático: os números racionais $(m / n)$, assim como os inteiros ( $m$ ou $n$ ), são, embora infinitos, contáveis (laboratoriáveis); os irracionais (números que não podem ser representados por uma fração; por exemplo: (Pi) $\pi$ ), infinitos-incontáveis (experimentáveis). Mais: o infinito dos números racionais, diz Cantor, é menor do que o infinito dos números irracionais. Cantor morreu louco, é claro. Cf. Joseph Warren Dauben, Georg Cantor: his mathematics and philosophy of the Infinite, Princeton: Princeton University Press, 1990. Também Kurt Godel pôs em evidência que a consistência da aritmética implica um limite, a incompletude, e que no interior desse sistema a consistência não pode ser demonstrada. Cf. Rebecca Goldstein, Incompletude: a prova e o paradoxo de Kurt Godel, São Paulo: Companhia das Letras, 2008.
} 
demonstrativa, exigindo uma nova imagem do pensamento. Sabe-se: a filosofia do ser aristotélica se compõe por três proposições sobre a existência dos entes na linguagem e no mundo (posteriormente, reunidas como "princípios" da lógica formal): princípio de identidade, que designa o ser como ser (Zacarias é mesmo Zacarias); princípio de nãocontradição, que impõe um encadeamento ao raciocínio (Todo homem é mortal $\rightarrow$ Zacarias é homem $\rightarrow$ Zacarias é mortal); princípio do terceiro excluído, que designa algo como verdadeiro ou falso (Zacarias é vivo ou morto: nunca pode ser, ao mesmo tempo, vivo-morto). O paradoxo vivo-morto é, portanto, algo repugnante à filosofia do ser, à lógica formal aristotélica. Enquanto esta lógica formal exige um encadeamento demonstrável e laboratorial [e o "ilógico do absurdo" é visto como uma espécie de "falha" no encadeamento (Todo homem é mortal $\rightarrow$ Zacarias é homem $\rightarrow$ Galinhas são verdes)], o paradoxo é a matéria e o ato do alógico - assim, como ocorre com as partículas subatômicas: simultaneidade. Mas é preciso transpor as dimensões do visível sem cair num misticismo platônico: mordendo o calcanhar do platonismo, os estoicos. Daí que o pensamento se faça topologia das forças do "fora", mas ganhando aqui uma nova questão: o deixar-se deslizar na fronteira do pensamento e do não-pensamento, no sem-fundo da superfície, no sem-fundamento, pensar o impensável.

Mas como pode o pensamento pensar o impensável? O que faz nascer o que numa concepção estrita se entende por "extra-ser" só é da ordem da explicação em uma abordagem leviana; trata-se muito mais de uma passagem para a "fronteira", a experiência lógica: aí, as personagens pirotécnicas tanto escapam ao modo de ser do unicamente "pensável" - ou seja, especialmente à representação ou à demonstração - quanto ao modo de ser do unicamente “impensável”. Uma zona extra-empírica - eis o que o extra-ser vivo-morto propõe como horizonte de pensamento. Ele potencializa modalidades de pensamento que requerem, além de outra língua crítica, outra lógica: imaginação, talvez. É inviável lê-lo a partir das mesmas plataformas pelas quais certas personagens de Alencar, de Balzac ou de Graciliano (e mesmo as de outro Rubião) são lidas. Poder-se-ia questionar: mas o que é o impensável senão algo definido pelo próprio pensamento? A grandeza inultrapassável, insubstituível ou imperial da razão não reclama que só se pode recorrer contra ela nela? Não está mesmo o inconsciente, do ponto de vista de Lacan, estruturado como uma linguagem? ${ }^{114}$ Não deve o pensamento pensar o que o forma e se formar com o que pensa? Diga-se que, no pensamento contemporâneo,

\footnotetext{
${ }^{114}$ Cf. Márcio Peter de Souza Leite, "O inconsciente está estruturado como uma linguagem”, in Oscar Cesarotto (org.), Ideias de Lacan, São Paulo: Iluminuras, 2001. Cf. também uma síntese da posição diferente de Deleuze em Eduardo A. Vidal, "Heterogeneidade Deleuze-Lacan", in Éric Alliez (org.), Gilles Deleuze: uma vida filosófica, São Paulo: Ed. 34, 2000. Em linhas gerais, a crítica de Deleuze ao conceito de inconsciente formulado por Lacan recai sobre uma suposta hegemonia do significante.
} 
nem sempre o mesmo vocabulário pode aspirar à identidade do significado: deve-se reconhecer que quase nunca se fala a mesma língua. Novamente é necessária uma imagem do pensamento que não deixe escapar a lógica do acontecimento: talvez aí se consiga uma imagem do pensamento impensável, tão singular como um golpe de sorte. Foucault afirma que três filosofias deixam escapar o acontecimento: "A primeira, a pretexto de que nada se pode dizer sobre o que está 'fora` do mundo, rejeita a pura superfície do acontecimento, e pretende encerrá-lo à força - como um referente - na plenitude esférica do mundo. A segunda, a pretexto de que só há significação para a consciência, localiza o acontecimento fora e antes, ou dentro e depois, situando-o sempre em relação ao círculo do eu. A terceira, a pretexto de que só há acontecimento no tempo, define sua identidade e o submete a uma ordem bem centrada". ${ }^{115}$ Portanto, o mundo, o eu e o Uno, tomados aqui como decisões filosóficas, são o que deixa escapar o acontecimento. O pensamento alheio à lógica do acontecimento tem então uma maneira peculiar de abordar o caos: renuncia ao impalpável buscando um referente, toma-o como algo suscetível à consciência, doma-o numa ordem, especialmente num significado último, vendo o passado como a essência para o relevo do futuro. Porém, para pensar o impensável o pensamento não pode ter a sua fonte nesta consciência fenomenológica das significações (desta consciência vem somente a figura engraçada que as crianças obedientes tentam desenhar quando um professor exigente lhes pede o desenho de um “circulo quadrado"). Da consciência provém alguma significação (Zacarias é homem), alguma gramática do ser (embora o privilégio concedido por tradição à consciência vígil não pode ser senão a certeza da incerteza), mas não a gramática do extra-ser. A consciência pode reconhecer ou perceber no máximo um laço artificial, em suas raízezinhas temporárias, em suas ínfimas crenças: a natureza alucinatória do objeto (o absurdo vivo-morto). E a expectativa moralmente boa de pensar conforme o senso comum tem mesmo este papel; no fundo, o de preservar a razão em sua "genialidade" singular. Mas a consciência não é um receptáculo adequado para metabolizar os dados da imaginação. Mesmo Bachelard dizia que pela imaginação se abandona o curso ordinário das coisas: "perceber e imaginar são tão antitéticos quanto presença e ausência". ${ }^{116}$ Para começar a pensar o impensável, é preciso desviar-se da consciência, é preciso, por assim dizer, “inconscientizar-se”: imaginar (“Crianças, não desenhem: Imaginem! Imaginem um círculo quadrado!”). Quando o

\footnotetext{
115 Michel Foucault, "Theatrum philosophicum" (1970), in Arqueologia das ciências e história dos sistemas de pensamento (Ditos e escritos - vol. 2), Rio de Janeiro: Forense Universitária, 2008, p. 238.

${ }_{116}$ Gaston Bachelard, $O$ ar e os sonhos: ensaio sobre a imaginação do movimento, São Paulo: Martins Fontes, 1990, p. 3. Sobre a questão da imaginação em Bachelard, cf. Rita Paiva, Gaston Bachelard: a imaginação na ciência, na poética e na sociologia, São Paulo: Annablume, 2005.
} 
unicamente pensável recai na impotência, a imaginação se impõe como reação, mas, nela, já não se vê nada além de uma noite do saber. Na imaginação, ou melhor, sobretudo na imaginação, o pensamento não obedece somente a uma convenção do "pensável", pela simples razão de que ele se torna vítima também do impensável: imaginar é, pois, pensar impensando - experiência lógica. A imaginação designa, em sua cifra misteriosa, na imperfeição do seu saber, em sua meia-luz, na presença que ela figura, para além do conteúdo da experiência humana, além mesmo do saber discursivo, a insistência ou a subsistência de algo que em todas as direções ultrapassa o "contável" (algo como o denominado "infinito matemático" de Georg Cantor). A flecha do impensável atravessa o pensável, faz nascer e renascer no leitor crítico uma espécie de "fantasmocrítica": um pensamento criador que aceita as divergências e as intransigências, um pensamento múltiplo, que não reagrupa nenhuma paisagem peremptória do mundo, que tem má vontade ante ao que poderia se tornar "alto" ou "profundo", por uma nova imagem do pensamento. Aí o pensamento é uma espécie de transe que sempre se renova e se reatualiza: vale a pena então pensar; um novo tipo de pensamento é possível; o pensamento, de novo, é possível. Trata-se, por uma tensão que renuncia à evidência das necessidades e das posições ocupadas, de ir até esse lugar neutro, onde as potências insignificantes figuram e obrigam a fazer outra espécie de pensamento, obrigado somente às regras de fronteira, região do pensamento impensável. Assim, não só o pensamento impensável é possível, como também só há pensamento na medida em que o impensável vem ao mesmo tempo declinar-se nele e nele pronunciar-se. O pensável: vivo, morto; o impensável: vivo-morto - assim, como um "circulo quadrado" (a sublime combinação do $e$ : ser circulo $e$ ser quadrado): ser-pensável e ser-impensável ao mesmo tempo, extra-ser: vivo-morto (Zacarias), mulher-Intangível (Marina), homem-boné (Anatólio), homem-bolinha (Artur), homem-bicho-e-verbo (Alfredo) - na propriedade simultânea de pensamento e a-pensamento; não-senso, pois. 
ARRIGUCCI JR., Davi. “O sequestro da surpresa”, in Outros achados e perdidos. São Paulo: Companhia das Letras, 1999.

BASTOS, Hermenegildo José. Literatura e colonialismo: rotas de navegação e comércio no fantástico de Murilo Rubião. Brasília: Editora da UNB, Plano Editora, 2001.

BATALHA, Maria Cristina. "Murilo Rubião e as armadilhas do verbo: a euforia e o desencanto", in Revista Letras \& Letras, Uberlândia, v. 19, p. 99-113, 2003.

BRUNN, Albert von. "Murilo Rubião: uma poética do emudecimento", in Wander Melo Miranda (org), A trama do arquivo. Belo Horizonte: UFMG, CEL/UFMG, 1995.

CANDIDO, Antonio. “A nova narrativa” (1979), in A educação pela noite. Rio de Janeiro: Ouro sobre Azul, 2006.

GREGOLIN, Maria do Rosário Valencise. "A reescritura como gênese da poética de Murilo Rubião", in Revista Estudos Linguísticos e Literários, Salvador, UFBA, v. 20, p. 55-63, 1997.

LINS, Álvaro. "Sagas de Minas Gerais" (1948), in Os mortos de sobrecasaca. Rio de Janeiro: Civilização Brasileira, 1963.

LUCAS, Fábio “A arte do conto de Murilo Rubião”, in Mineiranças. Belo Horizonte: Oficina de Livros, 1991.

MORAES, Marcos Antonio de (org.). Mário e o pirotécnico aprendiz (cartas de Mário de Andrade e Murilo Rubião). Belo Horizonte: Editora UFMG, São Paulo: IEB/USP, São Paulo: Editora Giordano, 1995.

MORAIS, Márcia Marques de. "Fantasmas (in)tangíveis nos contos de Murilo Rubião", in Revista Literatura e Sociedade, São Paulo, FFLCH/USP, v.10, p. 88-98, 2007/2008.

MOURÃO, Rui. “O pirotécnico Zacarias”, in Revista Colóquio, Lisboa, v. 25, p. 96-7, maio 1975.

NUNES, Benedito. "O convidado", in Revista Colóquio, Lisboa, v. 28, p. 91, novembro 1975.

PAES, José Paulo. "Um sequestro do divino", in A aventura literária: ensaios sobre ficção e ficções. São Paulo: Companhia das Letras, 1990.

PONCE, J. A. de Granville. "Entrevista - O fantástico Murilo Rubião", in Murilo Rubião, $O$ pirotécnico Zacarias. São Paulo: Ática, 1998.

RUBIÃO, Murilo. Obra Completa. São Paulo: Companhia das Letras, 2010.

SCHWARTZ, Jorge. Murilo Rubião: a poética do uroboro. São Paulo: Ática, 1981. 
SCHWARTZ, Jorge. "Do fantástico como máscara", in Murilo Rubião, O convidado: contos. São Paulo: Ática, 1983.

TARANTO, Audemaro Goulart. "A leitura epigráfica", in O conto fantástico de Murilo Rubião. Belo Horizonte: Lê, 1995.

BIBLIOGRAFIA - II (textos de apoio)

BARTHES, Roland. "Uma problemática do sentido" (1956), in Inéditos, I: teoria. São Paulo: Martins Fontes, 2004.

BARTHES, Roland. O neutro. São Paulo: Martins Fontes, 2003.

BLANCHOT, Maurice. O livro por vir. São Paulo: Martins Fontes, 2005.

BORBA, Maria Antonieta Jordão de Oliveira. Tópicos de teoria para a investigação do discurso literário. Rio de Janeiro: 7 Letras, 2004.

DAUBEN, Joseph Warren. Georg Cantor: his mathematics and philosophy of the Infinite. Princeton: Princeton University Press, 1990.

DELEUZE, Gilles. Lógica do sentido. São Paulo: Perspectiva, 2009.

DELEUZE, Gilles. Diferença e repetição. Rio de Janeiro: Graal, 2006.

FOUCAULT, Michel. "Introdução (in Binswanger)" (1954), in Problematização do sujeito: psicologia, psiquiatria e psicanálise (Ditos e escritos - vol. 1). Rio de Janeiro: Forense Universitária, 1999.

FOUCAULT, Michel. "Nietzsche, Freud, Marx" (1967) e "Theatrum philosophicum" (1970), in Arqueologia das ciências e história dos sistemas de pensamento (Ditos e escritos - vol. 2). Rio de Janeiro: Forense Universitária, 2008.

FREGE, Gottlob. "Sobre o sentido e a referência", in Lógica e Filosofia da Linguagem. São Paulo: Cultrix, 1978.

GOLDSTEIN, Rebecca. Incompletude: a prova e o paradoxo de Kurt Godel. São Paulo: Companhia das Letras, 2008.

GREIMAS, Algirdas Julien. Sobre o sentido: ensaios semióticos. Petrópolis: Vozes, 1975.

GUMBRECHT, Hans Ulrich. Production of presence: what meaning cannot convey. California: Stanford University Press, 2004.

LYOTARD, Jean-François. Discours, figure. Minneapolis: University of Minnesota Press, 2011. 
RICOEUR, Paul. Teoria da interpretação: o discurso e o excesso de significação. Lisboa: Edições 70, 2011.

RICOEUR, Paul. Da interpretação: ensaio sobre Freud. Rio de Janeiro: Imago, 1977.

TODOROV, Tzvetan. “Tipologia dos fatos de sentido", in Oswald Ducrot e Tzvetan Todorov, Dicionário enciclopédico das ciências da linguagem. São Paulo: Perspectiva, 2001.

BIBLIOGRAFIA - III (outros textos citados)

ADORNO, Theodor. "Museu Valéry Proust", in Prismas - crítica cultural e sociedade. São Paulo: Ática, 1998.

AGAMBEN, Giorgio. Infância e história: destruição da experiência e origem da história. Belo Horizonte: Editora UFMG, 2005.

ALAZRAKI, Jaime. "Qué es lo neofantástico?", in David Roas (org.), Teorías de lo fantástico. Madrid: Arco Libros, 2001.

ALLIEZ, Éric (org.). Gilles Deleuze: uma vida filosófica. São Paulo: Ed. 34, 2000.

ALLIEZ, Éric. Deleuze: filosofia virtual. São Paulo: Ed. 34, 1996.

ALMEIDA, Júlia. Estudos deleuzeanos da linguagem. Campinas: Ed. UNICAMP, 2003.

ALTER, Robert. "The dynamics of parallelism", in The art of biblical poetry. Berkeley: BasicBooks, 1985.

ALTER, Robert. "As características da antiga poesia hebraica", in Robert Alter e Frank Kermode (orgs.), Guia Literário da Bíblia. São Paulo: Editora UNESP, 1997.

AMÂNCIO, Moacir. “A fulguração de Ana”, in Revista de Estudos Orientais, FFLCH/USP, v.5, p. 119-126, 2006.

AUERBACH, Erich. “A cicatriz de Ulisses”, in Mimesis. São Paulo: Perspectiva, 2009.

AUSTIN, John Langshaw. Quando dizer é fazer: palavras e ações. Porto Alegre: Artes Médicas, 1990.

BACHELARD, Gaston. A poética do espaço. São Paulo: Martins Fontes, 2008.

BACHELARD, Gaston. A água e os sonhos: ensaio sobre a imaginação da matéria. São Paulo: Martins Fontes, 1997.

BACHELARD, Gaston. $O$ ar e os sonhos: ensaio sobre a imaginação do movimento. São Paulo: Martins Fontes, 1990.

BADIOU, Alain. Deleuze: o clamor do ser. Rio de Janeiro: Jorge Zahar, 1997.

BARTHES, Roland. O império dos signos. São Paulo: Martins Fontes, 2007. 
BERLIN, Adele. The Dynamics of Biblical Parallelism. Bloomington: Indiana University Press, 2008.

BLANCHOT, Maurice. "A literatura e o direito à morte", in A parte do fogo. Rio de Janeiro: Rocco, 2011.

BRAIT, Beth. A personagem. São Paulo: Ática, 2006.

BREMOND, Claude. "A mensagem narrativa", in Roland Barthes et al., Literatura $e$ Semiologia. Petrópolis: Vozes, 1972.

CAMARANI, Ana Luiza Silva. "Intertextualidade e frenético em Han d'Islande", in Lettres Françaises, São Paulo, FCL/UNESP/Araraquara, v. 5, p. 35-47, 2003.

CAMPOS, Haroldo de. "Serafim: um grande não-livro", in Oswald de Andrade, Serafim Ponte Grande. São Paulo: Globo, 1996.

CAMPOS, Haroldo de. "Paralelismo e sofisticação", in Bere'Shith: a cena da origem. São Paulo: Perspectiva, 2000.

CANDIDO, Antonio. "A personagem do romance", in Candido et al., A personagem de ficção. São Paulo: Perspectiva, 2000.

CARDOSO JR., Hélio Rebello. Teoria das multiplicidades no pensamento de Gilles Deleuze - Tese (Doutorado em filosofia), Universidade Estadual de Campinas (UNICAMP), 1996.

CESERANI, Remo. O fantástico. Curitiba: Ed UFPR, 2006.

COELHO, Nelly Novaes. "Guimarães Rosa e a tendência regionalista", in Affonso Ávila (org.), O Modernismo. São Paulo: Perspectiva, 1975.

CORTÁZAR, Julio. Valise de Cronópio. São Paulo: Perspectiva, 2008.

DELBAERE-GARANT, Jeanne. "Psychic realism, mythic realism, grotesque realism: variations on magic realism in contemporary literature in English", in Lois Parkinson Zamora e Wendy B. Faris, Magical realism: theory, history, community. Durham e London: Duke University Press, 1995.

DELEUZE, Gilles. Cinema 1 - A imagem-movimento. São Paulo: Brasiliense, 1985.

DELEUZE, Gilles. Cinema 2 - A imagem-tempo. São Paulo: Brasiliense, 1990.

ECO, Umberto. Seis passeios pelos bosques da ficção. São Paulo: Companhia das Letras, 2009.

FORSTER, Edward Morgan. "Pessoas" (capítulos 3 e 4), in Aspectos do romance. São Paulo: Globo, 2005.

FOUCAULT, Michel. As palavras e as coisas. São Paulo: Martins Fontes, 2007.

GENETTE, Gérard. Paratextos Editoriais. Cotia: Ateliê Editorial, 2009. 
GOLDMANN, Lucien. Sociologia do romance. Rio de Janeiro: Paz e Terra, 1967.

GOMES, Helder. “Arte, experimentação e vanguarda no pensamento de Jean-François Lyotard", in Revista Filosófica de Coimbra, Universidade de Coimbra, v. 21, p. 129-161, 2002 .

GREIMAS, Algirdas Julien. "Reflexões sobre os modelos atuacionais", in Semântica estrutural. São Paulo: Cultrix, 1976.

GREIMAS, Algirdas Julien. "A estrutura dos actantes da narrativa", in Sobre o sentido: ensaios semióticos. Petrópolis: Vozes, 1975.

HAMON, Philippe. "Para um estatuto semiológico da personagem", in Philippe Hamon et. al., Categorias da Narrativa. Lisboa: Arcádia, 1976.

HANSEN, João Adolfo. "Mímesis: figura, retórica \& imagem", in V Colóquio UERJ: Auerbach. Rio de Janeiro: Imago, 1994.

HARDT, Michael. Gilles Deleuze: um aprendizado em filosofia. São Paulo: Ed. 34, 1996.

INGARDEN, Roman. The cognition of the literary work of art. Evanston: Northwestern University Press, 1973.

ISER, Wolfgang. O ato da leitura: uma teoria do efeito estético. São Paulo: Ed 34, 1996.

KUGEL, James L. The Idea of biblical poetry: parallelism and its history. New Haven: Yale University Press, 1981.

LEITE, Márcio Peter de Souza. “O inconsciente está estruturado como uma linguagem”, in Oscar Cesarotto (org.), Ideias de Lacan. São Paulo: Iluminuras, 2001.

LEITE, Sebastião Uchoa. "O que a tartaruga disse a Lewis Carroll”, in Aventuras de Alice. São Paulo: Summus, 1980.

LÉVI-STRAUSS, Claude. De perto e de longe. Rio de Janeiro: Nova Fronteira, 1990.

LOPES, Luiz Manoel. A teoria do sentido em Deleuze - Tese (Doutorado em filosofia), Universidade Federal de São Carlos (UFSCar), 2006.

LUCAS, Fábio "O mundo das inscrições", in Fronteiras Imaginárias. Rio de Janeiro: Cátedra, 1971.

MACHADO, Roberto "A imagem-tempo", in Deleuze, a arte e a filosofia. Rio de Janeiro: Zahar, 2010.

MICOLET, Hervé. "Introduction”, in Bruno Gelas e Hervé Micolet (orgs.), Deleuze et les écrivains: littérature et philosophie. Nantes: Éditions Cécile Defaut, 2007.

PAIVA, Rita. Gaston Bachelard: a imaginação na ciência, na poética e na sociologia. São Paulo: Annablume, 2005. 
PAZ, Octavio. O arco e a lira. Rio de Janeiro: Nova Fronteira, 1982.

PAZ, Octavio. Os filhos do Barro. Rio de Janeiro: Nova Fronteira, 1984.

PAZ, Octavio. “A imagem” e “A consagração do instante”, in Signos em rotação. São Paulo: Perspectiva, 2009.

PELLAUER, David. Compreender Ricoeur. Petrópolis: Vozes, 2009.

PLATÃO. Sofista. São Paulo: Abril Cultural, 1983.

PROPP, Vladimir. Morfologia do conto maravilhoso. Rio de Janeiro: Forense, 1984.

PROUST, Marcel. Contre Sainte-Beuve. São Paulo: Iluminuras, 1988.

PUCHEU, Alberto. "Pelo colorido, para além do cinzento (quase um manifesto)", in Pelo colorido, para além do cinzento. Rio de Janeiro: Beco do Azougue, 2007.

PUCHEU, Alberto. "Poesia e filosofia", in Giorgio Agamben: poesia, filosofia e crítica. Rio de Janeiro: Beco do Azougue, 2010.

RICOEUR, Paul. A metáfora viva. São Paulo: Loyola, 2005.

ROAS, David. "La amenaza de lo fantástico", in David Roas (org.), Teorías de lo fantástico. Madrid: Arco Libros, 2001.

RODRIGUES, Selma Calasans. O fantástico. São Paulo: Ática, 1988.

SEGOLIN, Fernando. Personagem e anti-personagem. São Paulo: Olho d'água, 2006.

SPINDLER, William. "Magic realism: a typology", in Fórum for modern language studies, Oxford, n. 39, 1993.

TELES, Gilberto Mendonça. “O pequeno 'sertão' de Tutaméia”, in Navegações, Porto Alegre, PUC-RS, v. 2, p. 109-115, 2009.

TODOROV, Tzvetan. "Personagem", in Oswald Ducrot e Tzvetan Todorov, Dicionário enciclopédico das ciências da linguagem. São Paulo: Perspectiva, 2001.

TYNIANOV, J. “A noção de construção”, in Eikhenbaum et al., Os formalistas russos. Porto Alegre: Globo, 1978.

VALÉRY, Paul. "Le problème des musées", in Jean Hytier (ed), Paul Valéry - Oeuvres II. Paris: Gallimard, 1960.

VIDAL, Eduardo A. “Heterogeneidade Deleuze-Lacan”, in Éric Alliez (org.), Gilles Deleuze: uma vida filosófica. São Paulo: Ed. 34, 2000.

WAHL, François. "O copo de dados do sentido", in Éric Alliez (org.), Gilles Deleuze: uma vida filosófica. São Paulo: Ed. 34, 2000.

ZERAFFA, Michel. Pessoa e personagem: o romantismo dos anos de 1920 aos anos de 1950. São Paulo: Perspectiva, 2010. 